\title{
Assessment of Rangeland Ecosystem Conditions in Grand Canyon-Parashant National Monument, Arizona
}

Open-File Report $2020-1040$

U.S. Department of the Interior U.S. Geological Survey
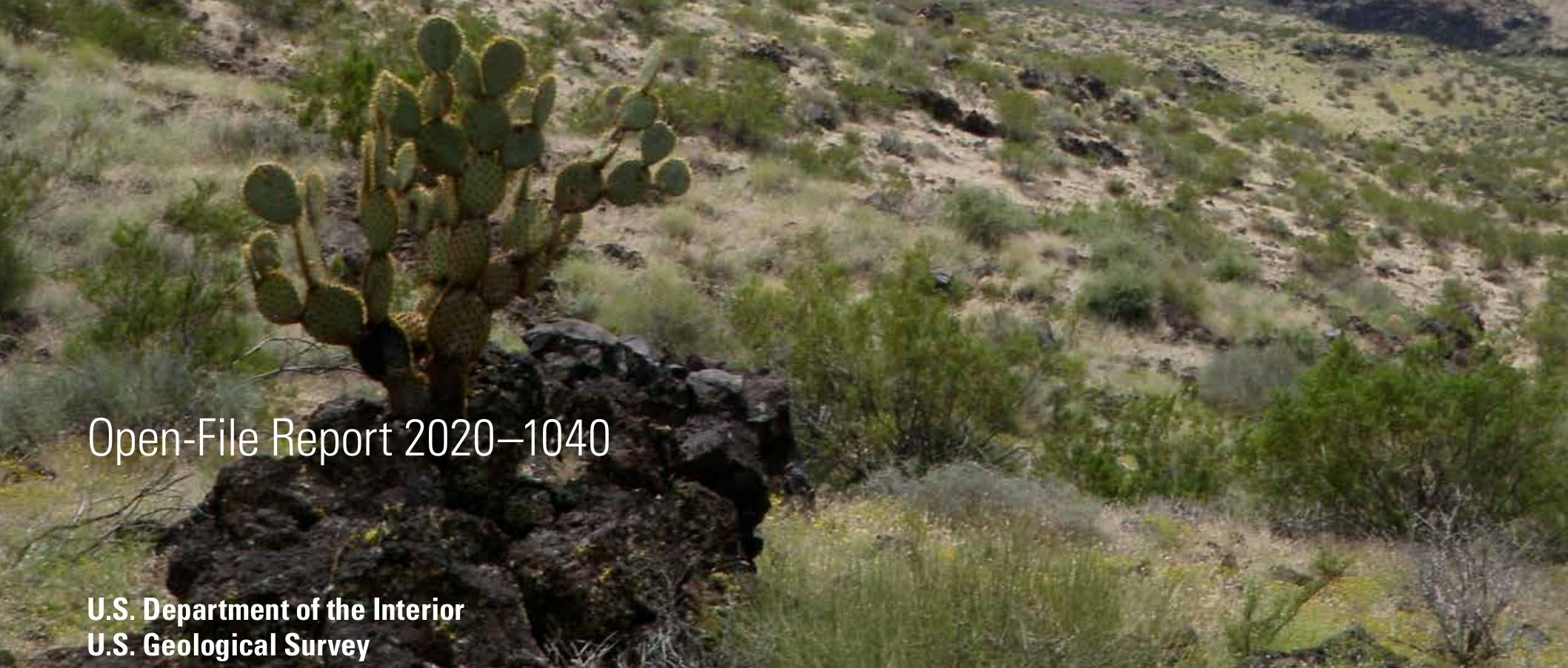
Cover. Photograph of the southern part of Whitmore Canyon, Grand Canyon-Parashant National Monument, Arizona. Photograph by E.C. Palmquist. 


\section{Assessment of Rangeland Ecosystem Conditions in Grand Canyon-Parashant National Monument, Arizona}

By Michael C. Duniway and Emily C. Palmquist

Open-File Report 2020-1040 


\title{
U.S. Department of the Interior DAVID BERNHARDT, Secretary
}

\author{
U.S. Geological Survey \\ James F. Reilly II, Director
}

\section{U.S. Geological Survey, Reston, Virginia: 2020}

For more information on the USGS - the Federal source for science about the Earth, its natural and living resources, natural hazards, and the environment-visit https://www.usgs.gov or call 1-888-ASK-USGS.

For an overview of USGS information products, including maps, imagery, and publications, visit https://store.usgs.gov.

Any use of trade, firm, or product names is for descriptive purposes only and does not imply endorsement by the U.S. Government.

Although this information product, for the most part, is in the public domain, it also may contain copyrighted materials as noted in the text. Permission to reproduce copyrighted items must be secured from the copyright owner.

Suggested citation:

Duniway, M.C., and Palmquist, E.C., 2020, Assessment of rangeland ecosystem conditions in Grand Canyon-Parashant National Monument, Arizona: U.S. Geological Survey Open-File Report 2020-1040, 42 p., https://doi.org/10.3133/ ofr20201040.

Associated data for this publication:

Duniway, M.C., and Palmquist, E.C., 2020, Vegetation and soils data from an assessment of rangeland ecosystem conditions in Grand Canyon-Parashant National Monument, Arizona. U.S. Geological Survey data release, https://doi.org/10.5066/P9SJSJHT.

ISSN 2331-1258 (online) 


\section{Acknowledgments}

We would like to acknowledge the advice and support provided to us by the National Park Service and Bureau of Land Management staff, specifically Brandon Boshell and Jennifer Fox.

Additionally, we had outstanding field assistance on this project from Erika Geiger, Lauren Mitchell, Henry Grover, Nick Kainrath, John Kao, Austin Rutherford, Paige Stuart, and Nora Talkington.

We would also like to thank Mark Miller for initiating this important project and providing early input into the design. Thanks also to Walt Fertig for assistance with plant identification. This work was funded by the Grand Canyon-Parashant National Monument and the U.S. Geological Survey Ecosystems Mission Area. 


\section{Contents}

Acknowledgments .............................................................................................................ii

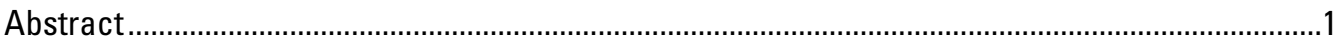

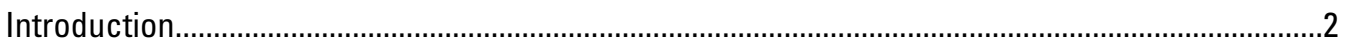

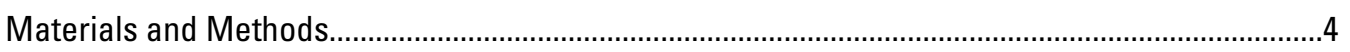

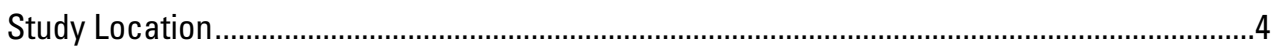

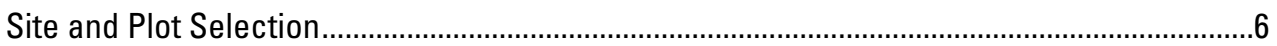

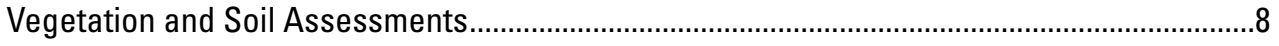

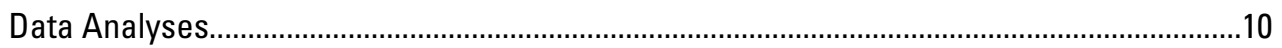

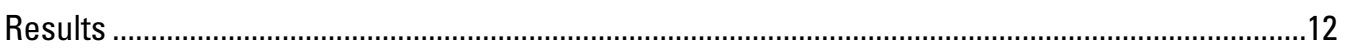

Soils, Ecological Sites, and Vegetation Communities Sampled ..............................................12

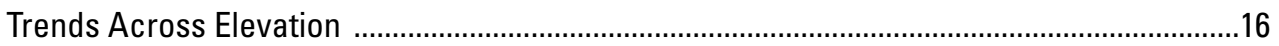

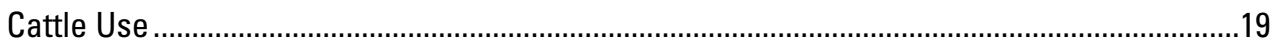

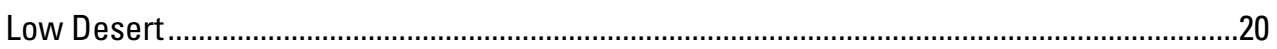

Landscape Setting, Soils, and Rangeland Indicators ....................................................20

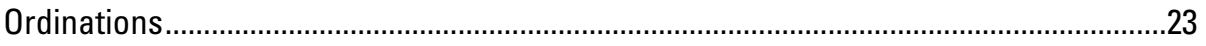

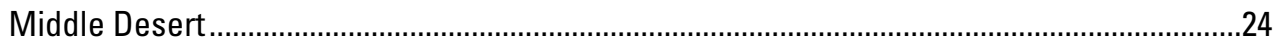

Landscape Setting, Soils, and Rangeland Indicators .................................................24

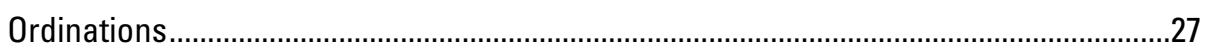

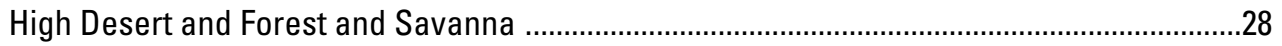

Landscape Setting, Soils, and Rangeland Indicators ....................................................

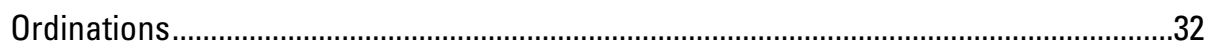

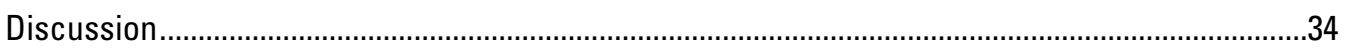

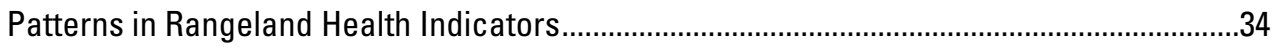

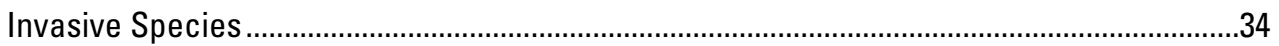

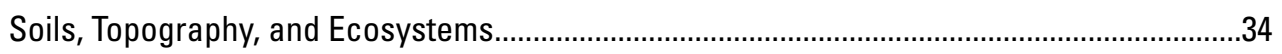

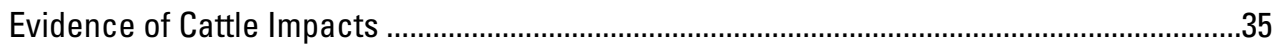

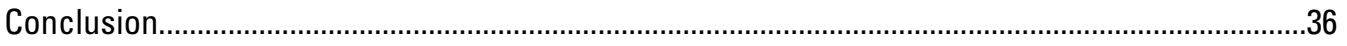

Appendix 1. Identification of Hydrologically Enhanced Areas...........................................................43 


\section{Figures}

1. Map showing the study area in the Grand Canyon-Parashant National Monument in the southwestern United States.......................................................................................

2. Plots showing the study area average monthly climatic conditions and weather

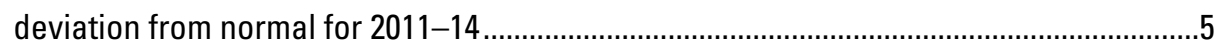

3. Maps of topographic-geomorphic units showing allotment and study

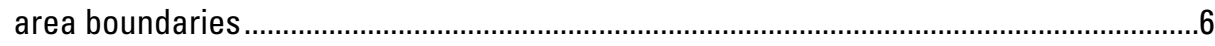

4. Maps of soil-geomorphic strata used for locating plots in the study area........................7

5. Maps showing example variable probability surfaces created for the eastern allotments in the study area ..........................................................................................

6. Maps showing the distribution of identified ecological site groups.................................11

7. Maps showing the spatial distribution of community clusters ........................................16

8. Plots showing trends in indicators of soil and site stability and hydrologic function

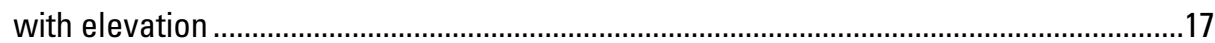

9. Plots showing trends in indicators of biotic integrity with elevation...............................18

10. Plots showing the relation between observed cow dung frequency and cost-distance to water, predicted forage production, and plot ruggedness index.........19

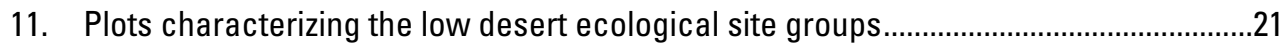

12. Plots showing fractional cover of the low desert ecological site groups .......................22

13. Plot showing correlations between rangeland health indicators, ordination axes, and landscape setting, soil, and cattle factors for low desert settings ..........................23

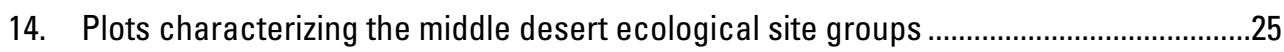

15. Plots showing fractional cover of the middle desert ecological site groups ..................26

16. Plot showing correlations among rangeland health indicators, ordination axes, and landscape setting, soil, and cattle factors for middle desert settings......................27

17. Plots characterizing the high desert and forest and savanna ecological site groups

18. Plots showing fractional cover of the high desert and forest and savanna ecological site groups

19. Plots showing correlations between rangeland health indicators, ordination axes, and landscape setting, soil, and cattle factors for high desert and forest and savanna settings. 


\section{Tables}

1. Indicators of rangeland health, association with attributes, and brief description ..........2

2. Study area allotments, size, permitted stocking rates, and season of use ........................5

3. Topographic classes and geologic parent material used in stratified random sampling design and extent mapped in study area

4. Final distribution of plots sampled by allotment and topographic-geologic grouping .....8

5. Landscape setting, soil, and cattle use variables hypothesized to control indicators of rangeland health and community ordinations...

6. Ecological site groups identified in the study area..........................................................13

7. Floristic groups identified in the study area ..................................................................14

8. Cross tabulation of ecological site groups and cluster analysis floristic groups............17

9. Richness and diversity indices for climate zones and floristic groups within .................18

10. Parameter estimates from multiple quantile regression estimating the 90 -percent quantile of cattle dung frequency in active grazing allotments.

11. Floristic groups in the low desert climate zone identified by cluster analysis and indicator species analysis

12. Floristic groups in the middle desert climate zone identified by cluster analysis and indicator species analysis.

13. Floristic groups in the high desert climate zone identified by cluster analysis and indicator species analysis.

14. Floristic groups in the forest and savanna climate zone identified by cluster analysis and indicator species analysis 


\section{Conversion Factors}

U.S. customary units to International System of Units

\begin{tabular}{|c|c|c|}
\hline Multiply & By & To obtain \\
\hline \multicolumn{3}{|c|}{ Length } \\
\hline inch (in.) & 2.54 & centimeter $(\mathrm{cm})$ \\
\hline inch (in.) & 25.4 & millimeter (mm) \\
\hline foot $(\mathrm{ft})$ & 0.3048 & meter $(\mathrm{m})$ \\
\hline mile (mi) & 1.609 & kilometer (km) \\
\hline \multicolumn{3}{|c|}{ Area } \\
\hline acre & 4,047 & square meter $\left(\mathrm{m}^{2}\right)$ \\
\hline acre & 0.4047 & hectare (ha) \\
\hline acre & 0.4047 & square hectometer $\left(\mathrm{hm}^{2}\right)$ \\
\hline acre & 0.004047 & square kilometer $\left(\mathrm{km}^{2}\right)$ \\
\hline square foot $\left(\mathrm{ft}^{2}\right)$ & 929.0 & square centimeter $\left(\mathrm{cm}^{2}\right)$ \\
\hline square foot $\left(\mathrm{ft}^{2}\right)$ & 0.09290 & square meter $\left(\mathrm{m}^{2}\right)$ \\
\hline square inch $\left(\mathrm{in}^{2}\right)$ & 6.452 & square centimeter $\left(\mathrm{cm}^{2}\right)$ \\
\hline square mile $\left(\mathrm{mi}^{2}\right)$ & 259.0 & hectare (ha) \\
\hline square mile $\left(\mathrm{mi}^{2}\right)$ & 2.590 & square kilometer $\left(\mathrm{km}^{2}\right)$ \\
\hline
\end{tabular}

Temperature in degrees Celsius $\left({ }^{\circ} \mathrm{C}\right)$ may be converted to degrees Fahrenheit $\left({ }^{\circ} \mathrm{F}\right)$ as ${ }^{\circ} \mathrm{F}=\left(1.8 \times{ }^{\circ} \mathrm{C}\right)+32$.

Temperature in degrees Fahrenheit $\left({ }^{\circ} \mathrm{F}\right)$ may be converted to degrees Celsius $\left({ }^{\circ} \mathrm{C}\right)$ as ${ }^{\circ} \mathrm{C}=\left({ }^{\circ} \mathrm{F}-32\right) / 1.8$. 


\section{Abbreviations}

\begin{tabular}{ll} 
BLM & Bureau of Land Management \\
ca. & circa \\
cm & centimeters \\
CRA & Conservation Resource Area \\
DEM & Digital Elevation Model \\
DIMA & Database for Inventory, Monitoring, and Assessments \\
ESD & ecological site description \\
ESG & ecological site groups \\
GMP/RMP & Joint NPS Grazing Management Plan/BLM Resource Management Plan \\
GPS & Global Positioning System \\
GRTS & general randomized tessellation stratification \\
ha & hectares \\
LPI & line point intercept \\
m & meters \\
mm & millimeters \\
MLRA & Major Land Resource Area \\
N & number \\
NMS & nonmetric multidimensional scaling \\
NPS & National Park Service \\
NRCS & Natural Resources Conservation Service \\
$p$ & probability value \\
$r$ & correlation coefficient \\
spp. & species \\
TWI & topographic wetness index \\
USDA & U.S. Department of Agriculture \\
USGS & U.S. Geological Survey \\
\hline
\end{tabular}




\title{
Assessment of Rangeland Ecosystem Conditions in Grand Canyon-Parashant National Monument, Arizona
}

\author{
By Michael C. Duniway and Emily C. Palmquist
}

\section{Abstract}

Sustainability of dryland ecosystems depends on the functionality of soil-vegetation feedbacks that affect ecosystem processes, such as nutrient cycling, water capture and retention, soil erosion and deposition, and plant establishment and reproduction. Indicators that represent these fundamental processes are central to many approaches for ecosystem assessment and monitoring in drylandscollectively they are referred to as "rangeland health." Evaluation of rangeland health relies on describing the condition and sustainability of these individual, measurable, or observable indicators that are linked to important ecosystem processes. Useful, common indicators can provide information on soil and site stability, hydrologic function, and biotic integrity. Quantitative approaches to rangeland health evaluations allow for robust and reliable evaluations of trends through time (that is, monitoring) and serve as the basis for several national rangeland monitoring programs. However, management-relevant interpretations of rangeland health assessments require contextual information on how soils, landscape, and climate setting are shaping ecosystem qualities and some estimate of what constitutes target values of a healthy system.

The approximately one-million-acre Grand CanyonParashant National Monument is located in the northwest corner of Arizona and co-managed by the Bureau of Land Management (BLM) and National Park Service (NPS). This report focuses on the circa (ca.) 200,000 acres of NPSadministered lands in the monument — one of the largest NPS units where livestock grazing is a permitted land-use activity. Many ecosystems in the monument are characterized by a low degree of resilience to improper grazing because of low and variable precipitation. Grand Canyon-Parashant National Monument is marked by a high degree of environmental heterogeneity, including a large elevation gradient, widely differing precipitation patterns, a diversity of geologic substrates, and unique combinations of plant species.

The objective of this report is to (1) increase our understanding of the underlying landscape, soil, and climate setting factors that affect Grand Canyon-Parashant National Monument dryland ecosystem structure and function (also referred to as land potential) and (2) characterize the condition of Grand Canyon-Parashant National Monument ecosystems in relation to management concepts, such as rangeland health. The results discussed here on ecosystem condition, coupled with the increased understanding of soil-geomorphic controls on vegetation distribution within Grand Canyon-Parashant National Monument, provide information to help managers develop appropriate livestock management strategies.

Locations for rangeland assessments were selected using a stratified, spatially balanced random sampling method based on allotment, soil type, slope, distance to cattle water locations, and accessibility. A total of 155 plots were established and sampled between March and November of 2012 and 2013. Data collection at each plot included soil-geomorphic setting descriptions, plant and soil cover, and soil aggregate stability. Data were analyzed by elevation zone using both univariate and multivariate approaches. Survey results document the high level of diversity within the study area, including 15 unique soil taxa (to great group level) and 271 species of plants. We collected three new plant species for Grand Canyon-Parashant National Monument and 17 new species for the NPS portion of Grand Canyon-Parashant National Monument.

Results also document a strong association between rangeland health indicators and elevation, topographic setting, and soils. Soil factors found to explain important variation across plots include the amount of exposed bedrock, soil rockiness, soil texture (and associated hydrologic properties), and soil depth. We also found that dominant species turnover across elevation may represent species' differences in adaptation to climates, including Larrea tridentata, Coleogyne ramosissima, and Artemisia spp. Bromus rubens is the most common invasive species of concern recorded in this study, but other common invasive species are Bromus tectorum, Erodium cicutarium, and Schismus arabicus. Correlations between an index of cattle use and indicators of rangeland health suggest that areas with high cattle use have increased bare ground, decreased ground cover, increased frequency of Schismus arabicus, decreased cover of Coleogyne ramosissima and Ephedra spp., and increased cover of Gutierrezia spp. The few strong correlations observed between indicators of vascular plant community cover or abundance and indicators of cattle activity support rangeland assessment and monitoring strategies that do not rely solely on plantbased indicators are needed. 
This work supports management of dryland ecosystems, including Grand Canyon-Parashant National Monument, using concepts of land potential. Land-potential-based classification systems use climate, soils, and topographic properties to classify landscapes based on potential productivity, composition, and response to climate and management. We conclude the report with recommendations on improving existing land-potential-based classification systems, associated interpretations, and methods for moving forward with a Grand Canyon-Parashant National Monument rangeland monitoring program.

\section{Introduction}

Sustainability of dryland ecosystems, including ecosystem resilience to climate disturbances and anthropogenic stressors, depends on ecosystem capacity for capturing and retaining scarce resources (Whitford, 2002). This capacity is largely controlled by soil-vegetation feedbacks that affect ecosystem processes, such as nutrient cycling, water capture and retention, and soil erosion and deposition, as well as plant demographic processes, such as establishment and reproduction (Tongway and Ludwig, 1997; Whitford, 2002). Because of their importance for the functionality and dynamics of dryland ecosystems, as well as their sensitivity to land-use impacts (Tongway and others, 2003; Neff and others, 2005), indicators of these processes are central to many approaches for ecosystem assessment and monitoring in drylands and collectively referred to as "rangeland health" (National Research Council, 1994; Pyke and others, 2002; Tongway and Hindley, 2004; Herrick and others, 2005; Pellant and others, 2005).

Evaluation of rangeland health does not rely on one single response variable, but rather a suite of fundamental attributes that describe the condition and sustainability of drylands. Three attributes are increasingly recognized as fundamental to condition and sustainability: soil and site stability, hydrologic function, and biotic integrity (National Research Council, 1994; Pyke and others, 2002). Soil and site stability refers to the capacity of a plot or area to minimize redistribution and otherwise retain soil resources against the erosive forces of wind and water. Hydrologic function pertains to a plot or area's ability to capture, store, and safely release incoming precipitation or overland flow. Biotic integrity refers to a plot or an area's biotic community, including plants, animals, insects, and soil biota, and its ability to support ecological processes and recover these processes when disturbed. Assessment of rangeland health attributes uses individual, measurable indicators that are linked to important ecosystem processes, such as amount of foliar cover or exposed bare ground. Evaluation of the three attributes of rangeland health utilizes both qualitative assessments (Pyke and others, 2002; Herrick and others, 2010) and quantitative approaches (Herrick and others, 2005; Duniway, Herrick, and others, 2010; Duniway and Herrick, 2013) (table 1).

Quantitative approaches to rangeland health evaluations allow for robust and reliable evaluation of trends through time (monitoring) and serve as the basis for several national and regional rangeland monitoring programs (Nusser and Goebel,

Table 1. Indicators of rangeland health, association with attributes, and brief description (adapted from Pellant and others [2005] and Duniway, Herrick, and others [2010]).

[SSS, soil and site stability; HF, hydrologic function; BI, biotic integrity; cm, centimeters; mm, millimeters; $\mathrm{m}^{2}$, square meters]

\begin{tabular}{|c|c|c|c|c|c|}
\hline \multirow{2}{*}{ Quantitative indicator } & \multirow{2}{*}{$\begin{array}{l}\text { Expected } \\
\text { correlation }\end{array}$} & \multicolumn{3}{|c|}{ Attribute } & \multirow{2}{*}{ Description } \\
\hline & & SSS & HF & BI & \\
\hline Basal gaps $>200 \mathrm{~cm}$ & - & - & $\bullet$ & & Fraction of plot in basal gaps $>200 \mathrm{~cm}$ \\
\hline Bare ground & - & $\bullet$ & $\bullet$ & & Fraction of plot with no foliar, litter, or soil cover \\
\hline Ground cover & + & $\bullet$ & & & Fraction of plot with ground cover (biological soil crust, litter, rock, basal) \\
\hline Lichen & + & $\bullet$ & & $\bullet$ & Fractional soil cover of lichens \\
\hline Moss & + & • & & $\bullet$ & Fractional soil cover of mosses \\
\hline $\begin{array}{l}\text { Soil surface (top few mm) } \\
\text { resistance to erosion }\end{array}$ & + & $\bullet$ & $\bullet$ & $\bullet$ & $\begin{array}{l}\text { Average soil aggregate stability index (1-6) measure of water stable } \\
\text { aggregates }\end{array}$ \\
\hline Functional/structural groups & $+/-$ & & $\bullet$ & $\bullet$ & Fractional cover by plant life form and duration \\
\hline Invasive species & - & & & $\bullet$ & Rooted frequency ( $1 \mathrm{~m}^{2}$ quadrat $)$ of species of concern \\
\hline
\end{tabular}

${ }^{1}$ Expected correlation (positive, negative, or both) with indicators of rangeland health. 
1997; Toevs and others, 2011; National Park Service, 2016), though this type of approach can be difficult to implement for some soil and site stability and hydrologic function indicators (Duniway, Herrick, and others, 2010). Standard methods for collecting rangeland data that allow for quantitative estimates of rangeland health indicators are now well established (Herrick and others, 2005; Toevs and others, 2011) and widely used. These quantitatively derived indicators can be then used for management-relevant interpretations, such as datadriven state-and-transition models (Miller and others, 2011), evaluating risk of accelerated erosion (Webb and others, 2014), and detection of leading indicators of state change (Bestelmeyer and others, 2013). However, interpretation of indicator values and meaningful assessment of rangeland health attributes requires contextual information on how soils, landscape, and climate setting are shaping ecosystem qualities and some estimate of what constitutes target values of a healthy system.

Risks of persistent, undesirable changes in ecosystem structure and function are dependent on inherent properties that confer resistance and resilience to drivers of change, as well as the degree of exposure to drivers (for example, livestock grazing; Archer and Stokes, 2000; Herrick and others, 2006). Whereas ecosystem resistance and resilience can change in relation to varying climatic conditions and dynamic ecosystem properties affected by climate, land use, and management (Bestelmeyer and others, 2015), they are also strongly controlled by ecosystem properties that are generally stable through time. Inherent soil properties (for example, rock content, texture, depth, mineralogy) and geomorphic setting are among the most important factors controlling ecosystem resistance and resilience to land-use activities (Duniway, Bestelmeyer, and others, 2010), but specific relations between soil-geomorphic properties and ecosystem dynamics are poorly understood on a regional basis (Duniway and others, 2016).

The Grand Canyon-Parashant National Monument is one of the largest National Park Service (NPS) units where livestock grazing is a permitted land-use activity (fig. 1). The Bureau of Land Management (BLM), which co-manages the monument, administers nine allotments on the NPS portion of the monument, some of which are closed to grazing and some of which are actively grazed. Like many arid regions globally, some ecosystems in Grand CanyonParashant National Monument are characterized by a low degree of resilience to improper grazing. Unique to Grand Canyon-Parashant National Monument is the high degree of environmental heterogeneity encompassed by these nine allotments. Situated on the northwestern edge of the Grand Canyon, these allotments contain a large elevation gradient, widely differing precipitation patterns, a diversity of geologic substrates, and unique combinations of plant species. This area is also remote and difficult to travel in. Combined, these ecosystem characteristics make this area particularly complex to understand and therefore manage. Despite the broad spatial extent of grazing activity in Grand CanyonParashant National Monument, and the sensitivity of dryland ecosystems to associated impacts, monument managers have little information regarding effects of past and current livestock grazing on the condition of rangeland resources within the monument.

Rigorous scientific information documenting the current condition of rangeland ecosystems in relation to land use and climate is needed to make progress towards achieving resource protection goals (for example, those identified in the 2008 joint NPS General Management Plan/BLM Resource Management Plan for the monument [GMP/RMP]). One goal specifically called for in the GMP/RMP is the identification of "vital signs" (indicators and attributes of ecosystem health) and the implementation of a long-term program to monitor vital signs as a means of evaluating grazing effects on vegetation, soil, and watershed conditions. The GMP/RMP prescribes an adaptive management approach to grazing, whereby monitoring results are evaluated against applicable indicators and associated standards and are used to refine NPS and BLM grazing management. Refinement may include changes to season of use or timing, rest, grazing intensity, more active herd management within pastures, deferment, or other actions. Adaptive management would be aimed at retaining or restoring ecosystem resilience and resource sustainability while minimizing risks of impairment to resources or ecological processes.

This project focuses on two scientific issues: (1) understanding the underlying landscape, soil, and climate setting factors that affect Grand Canyon-Parashant National

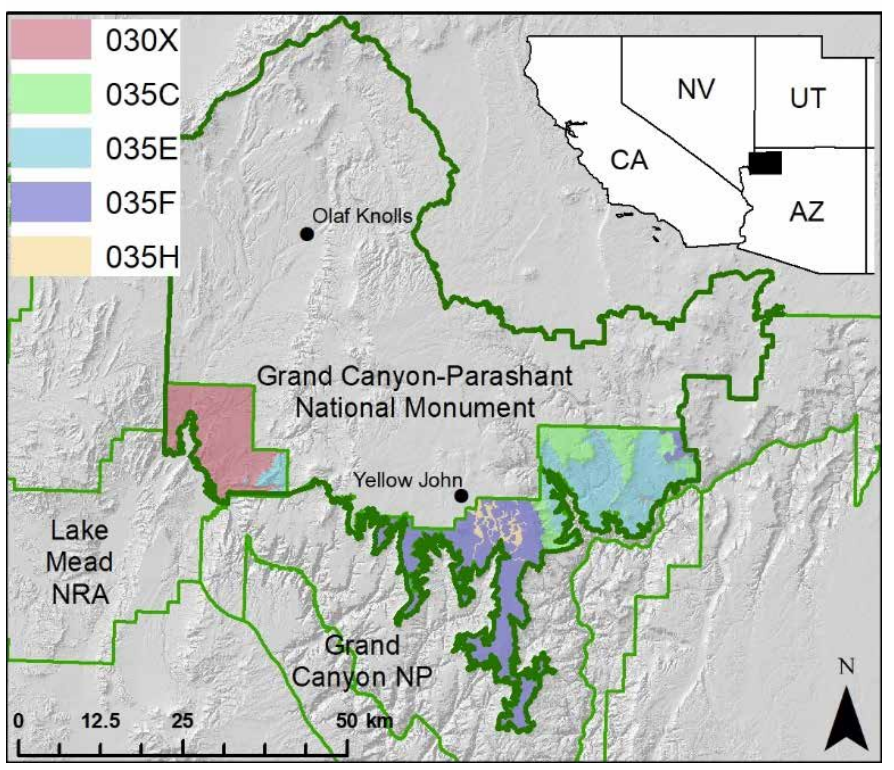

Figure 1. Map showing the study area in the Grand CanyonParashant National Monument in the southwestern United States. The monument is outlined in dark green. Land management agency boundaries are shown in light green. Natural Resources Conservation Service (NRCS) Major Land Resource Areas and Land Resource Units within the study area are shown by various colors (Lindsay and others, 2003; Natural Resources Conservation Service, 2006); land resource codes are defined in table 3. Black dots indicate weather station locations. NRA, National Recreation Area; NP, National Park; km, kilometers. 
Monument dryland ecosystem structure and function (also referred to as land potential) and (2) characterizing ecosystem condition in relation to management concepts, such as rangeland health. This assessment project aims to provide information required to facilitate prioritization for restoration, monitoring, or other activities that support resource protection goals and thereby allow for further evaluation of the adequacy of current grazing management practices on NPS lands. The specific objectives of this work were to collect rangeland ecological condition inventory data from the nine allotments within the NPS-managed portion of the monument, provide interpretations on these results as they pertain to monument management, and include some suggestions for the next steps. The results included here on ecosystem condition, coupled with the increased understanding of soil-geomorphic controls on vegetation distribution within Grand Canyon-Parashant National Monument, will enable managers to develop appropriate livestock management strategies.

\section{Materials and Methods}

\section{Study Location}

Field studies were conducted on NPS-administered lands within Grand Canyon-Parashant National Monument (fig. 1). This area comprises more than 200,000 acres $(80,937$ hectares [ha]) of the approximately $1,000,000$-acre (404,686 ha) monument located in the northwest corner of Arizona. This area is bordered on the south and east by Grand Canyon National Park, to the north by BLMadministered lands of Grand Canyon-Parashant National Monument, and to the west by the BLM's Southern Nevada District and Lake Mead National Recreation Area. Elevation ranges from approximately 400 to more than 2,000 meters (m). The low-elevation western side of the study area is characterized by Mojave Desert flora (Major Land Resource Area [MLRA] 030, Mohave Basin and Range; Natural Resources Conservation Service, 2006). The eastern side of the study area is dominated by large canyon benches with diverse vegetation communities because of the influence of the Mojave Desert, the Great Basin, and the Sonoran Desert, and to a lesser degree the Colorado Plateau (MLRA 035). The high-elevation parts in the center of the study area are largely pinyon-juniper stands with some ponderosa pine occurring in patches. Of the 1,095 plant species recorded in Grand CanyonParashant National Monument to date, 681 species are listed for the NPS-managed land, of which 135 only occur on NPSmanaged lands, and new species records are regularly reported (Hildebrand and Fertig, 2012). Climate regimes vary from arid in the low reaches to mesic at high elevations. Average annual precipitation ranges from 204 to 405 millimeters (mm). Low elevation areas are warm to hot (monthly average ranges from a low of $8{ }^{\circ} \mathrm{C}$ in December to a high of $32{ }^{\circ} \mathrm{C}$ in July) and higher reaches of Grand Canyon-Parashant National Monument are cool to cold (monthly average ranges from a low of $-1.4{ }^{\circ} \mathrm{C}$ in December to a high of $21^{\circ} \mathrm{C}$ in July) with significant snow accumulation in some winters (fig. 2).

The monument straddles the Colorado Plateau and Great Basin physiographical provinces, separated by the Grand Wash Cliffs (Billingsley and others, 2004). Eastern Grand Canyon-Parashant National Monument falls within the Colorado Plateau (the Sanup and Shivwits Plateaus) and is dominated by structural benches and mesas formed from Paleozoic limestones, sandstones, and gypsiferous mudstones. Soils in these settings are formed from residuum, colluvium, and alluvium of varying geologic sources. To the west of the Grand Wash Cliffs lies the lower Basin and Range Province (Grand Wash trough), which is dominated by Tertiary and Quaternary sedimentary deposits (Billingsley and others, 2004). There are several prominent Tertiary-aged basalt flows that occur in both the western and eastern parts of the study area (Billingsley and others, 2004). The diversity of climatic conditions and variety of geologic substrate of Grand CanyonParashant National Monument together have produced a wide range of soil types. The most recent soil survey (Lindsay and others, 2003), though done at a coarse scale (1:24,000 scale mapping), includes 65 unique soil map unit components in the study area.

As in much of the western United States, grazing in this area has been an important land-use activity since the 1880 s (Rider and Paulsen, 1985; Godfrey, 2008) with likely profound ecosystem impacts (Fleischner, 1994). Prior to the Taylor Grazing Act of 1934, grazing across the western United States was largely unregulated, with stocking rates generally higher than sustainable (Godfrey, 2008). After the establishment of the BLM and subsequent grazing management, stocking rates have generally been reduced. Grazing in low-elevation areas on the west side of Grand Canyon-Parashant National Monument is typically permitted year round, and, because of low forage availability, at fairly low intensities. In the midelevation areas, grazing occurs during the winter and into early summer. High elevation reaches were used historically in the summer (table 2). The study area is currently divided into nine allotments, some of which are separated into pastures for grazing management. There are several allotments where grazing does not currently occur. These include the Tassi allotment on the western edge, in which cattle use was disallowed in 2001 because of endangered species concerns (Gopherus agassizii; fig. 3). There were several wild burro and trespassing cattle in the Tassi allotment, but most cattle were rounded up in 2013. In the eastern study area, one allotment (Lone Mountain) has not experienced appreciable grazing by domestic livestock because of inaccessibility, however we were not able to collect field data from this allotment. Finally, there has been no domestic grazing in the Home Ranch allotment since 2003 . 

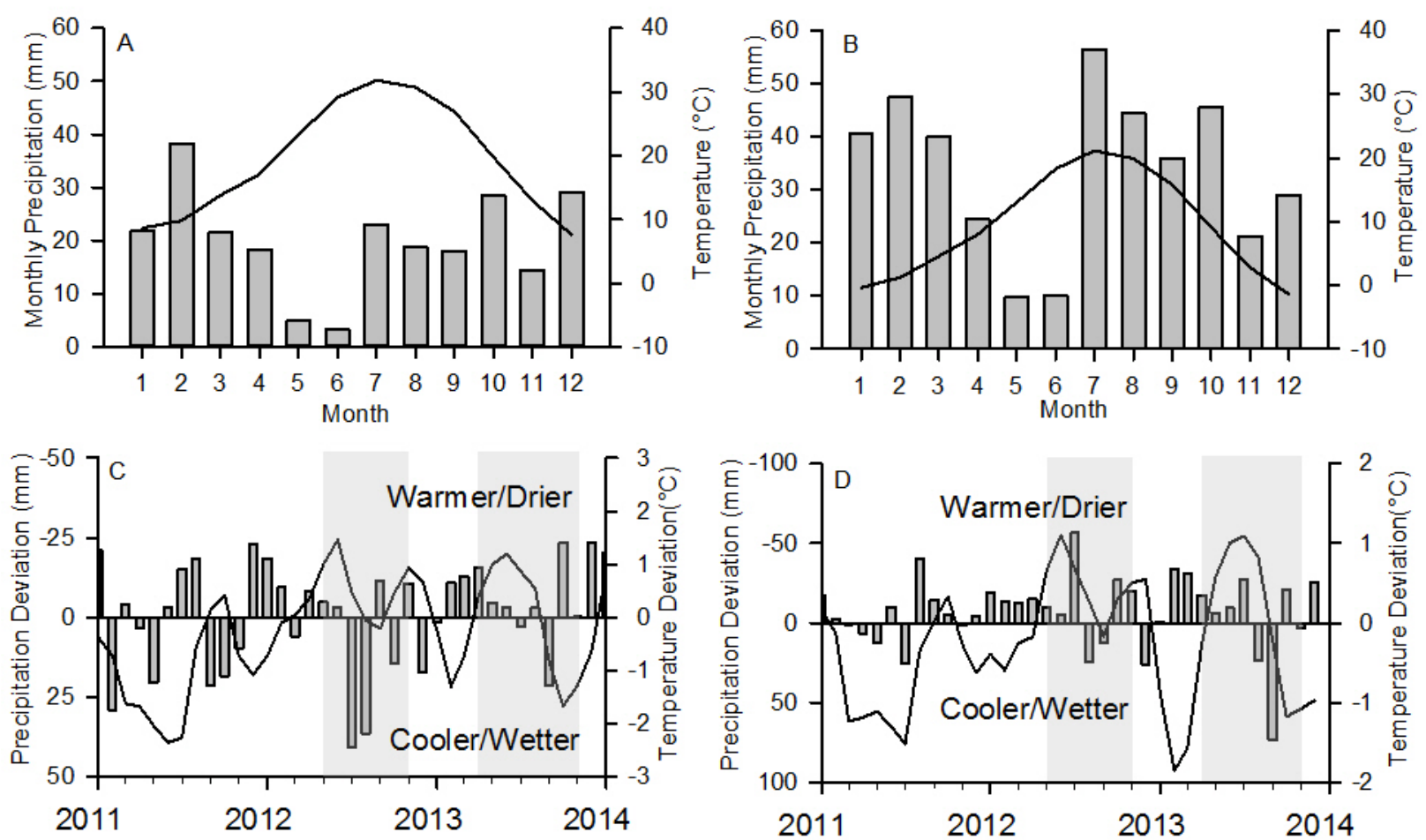

Figure 2. Plots showing the study area average monthly climatic conditions $(A$ and $B)$ and weather deviation from normal for 2011-14 $(C$ and $D)$. Weather deviation is shown for one year prior to and during the two-year sampling period (sample periods indicated by gray fill). Plots $A$ and $C$ show data from a low-elevation weather station (884 meters; Olaf Knolls in fig. 1). Plots $B$ and $D$ show data from a high-elevation weather station (1,878 meters; Yellow John in fig. 1). Data from the Western Regional Climate Center (http://www.wrcc.dri.edu); long-term average based on the record period from 1985 to 2016. mm, millimeters; ${ }^{\circ} \mathrm{C}$, degrees Celsius.

Table 2. Study area allotments, size, permitted stocking rates, and season of use.

[Data from Bureau of Land Management Rangeland Administration System Reports, accessed June 25, 2019, at https://reports.blm.gov/reports/RAS. Billed animal unit months (AUMs) are averaged for 1990 to 2014; data accessed October 15, 2015, at https://reports.blm.gov/reports/RAS. NA, not applicable]

\begin{tabular}{lcccl}
\hline \multicolumn{1}{c}{ Allotment } & Area, in hectares $^{1}$ & AUMs $^{2}$ & Billed AUMs $^{3}$ & \multicolumn{1}{c}{ Season of use $^{\text {1 }}$} \\
\hline Big Spring Pipeline & 23,358 & 2,789 & 1,266 & Year round $^{4}$ \\
Dripping Spring & 4,690 & 448 & 323 & Nov.-May \\
Home Ranch & 30,890 & - & 1,152 & NA \\
Mt. Trumbull & 13,463 & 1,825 & 1,175 & Year round \\
Mule Canyon & 7,022 & 585 & 338 & Nov.-May \\
Pa's Pocket & 3,518 & 479 & 276 & Dec.-Apr. \\
Red Pond & 22,280 & 2,508 & 1,144 & Year round \\
Tassi & 45,150 & - & 1,024 & NA \\
\hline
\end{tabular}

${ }^{1}$ Hectares totaled within allotment corresponding to AUMs from Rangeland Administration System Reports.

${ }^{2}$ Animal unit months, based on authorized use as of June 25, 2019.

${ }^{3}$ Dripping Spring data missing 2003-2005, Pa's Pocket data only available 2001-2014, Home Ranch data ends in 2003, and Tassi data ends in 2000.

${ }^{4}$ Numbers reduced by about one-third for Oct.-Feb.

${ }^{5}$ Numbers reduced by about one-third for Mar--May.

${ }^{6}$ Numbers reduced by about one-third for Mar--Apr. 

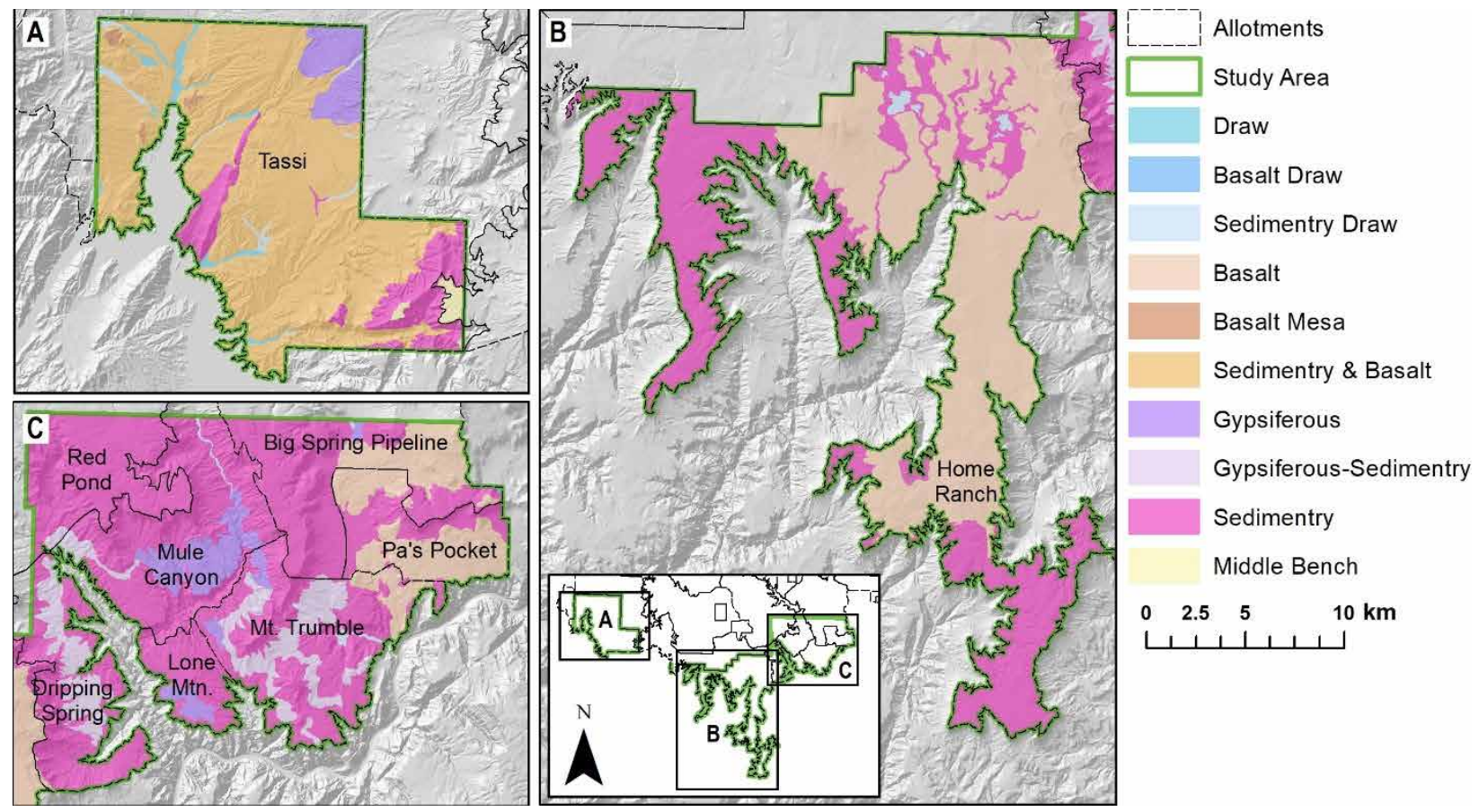

Figure 3. Maps of topographic-geomorphic units showing allotment and study area boundaries. Soil-geomorphic units based on soil survey map unit descriptions (Lindsay and others, 2003). Map inset shows the part of the Grand CanyonParashant National Monument that the National Park System administers (outlined in green). km, kilometers.

\section{Site and Plot Selection}

To account for the high degree of heterogeneity imposed by abiotic factors in the study area, we employed a stratified random sampling scheme based on climate, soil, and topographic factors. We first attempted to use Natural Resources Conservation Service (NRCS) ecological site descriptions (ESDs), which are assigned to soil survey map unit components (Lindsay and others, 2003; Duniway, Bestelmeyer, and others, 2010). However, there were too many unique ESDs in the study area to use as strata $(\mathrm{N}>60)$. Given the importance of soil parent material and topographic setting in controlling dryland ecosystem dynamics, we used geologic parent material groups and topographic setting as soil-geomorphic strata. We used the soil parent material data (as described in the soil survey map units; Lindsay and others, 2003), to create three geologic groups (table 3). Given the importance of slope in governing plant community dynamics and cattle distribution, we further subdivided soil map units by slope (into three groups). Slope and other terrain derivatives were calculated using Spatial Analyst in Esri's ArcGIS ver. 10.1 and a 10-m digital elevation model (DEM) from the U.S. Geological Survey (USGS) National Elevation Dataset (https://nationalmap.gov).

To capture areas that are likely more productive, and therefore important from a livestock forage perspective, we used a simple supervised classification approach to pick out shallow slope areas $\left(<8^{\circ}\right)$ that likely accumulate overland flow from the surrounding landscape ("run-in") (Rango and others, 2006). Methods used to map these hydrologically enhanced areas are described in appendix 1 . To further reduce the number of strata, we did not cross slope and topographic setting with parent material for the run-in and steep-slope strata (fig. 3). For both run-in and steep-slope locations, we anticipated that the influence of topographic setting would most often overwhelm that of surficial geology.

To ensure an adequate number of study plots in each livestock management unit, we further stratified our sampling by Grand Canyon-Parashant National Monument allotment. Two allotments spanned large precipitation gradients (Big Spring Pipeline and Pa's Pocket) and for these two allotments we further divided the strata by zones identified in the soil survey (Common Resource Areas [CRAs] precipitation zones: 6-10, 10-14, 13-17, and 17-25 inches annually; fig. 1). Sample draws were done for each strata within each allotment separately using the general randomized tessellation stratification (GRTS) method to generate random, spatially balanced plot locations (Stevens and Olsen, 2004) with the geostatistical analysis tools in ArcGIS ver. 10.1. Not all strata occurred in each allotment, resulting in a variable number of strata in each allotment (fig. 4). We allocated more sampling effort to large allotments and landscape settings likely to receive high use by livestock (run-in and other shallow-slope sites; table 4). The GRTS approach provides a random order of selection for each sample draw, allowing users to not sample all selected points either because of predefined rejection criteria or inadequate time.

We used a variable probability surface with a $10-\mathrm{m}$ pixel size (snapped to the DEM) within each allotment and strata to increase the probability of obtaining a grazing gradient in 
Table 3. Topographic classes and geologic parent material used in stratified random sampling design and extent mapped in study area (in hectares).

\begin{tabular}{|c|c|c|c|c|c|c|c|}
\hline Topographic class & $\begin{array}{c}\text { Geologic parent } \\
\text { material }\end{array}$ & 030X & $\mathbf{0 3 5 C ^ { 2 }}$ & $035 \mathrm{E}^{3}$ & $\mathbf{0 3 5 F ^ { 4 }}$ & $\mathbf{0 3 5 H ^ { 5 }}$ & Total \\
\hline \multirow[t]{6}{*}{ Shallow slopes $\left(<8^{\circ}\right)$} & & 2,951 & 3,581 & 8,298 & 24,145 & 2,039 & 45,905 \\
\hline & Run-in & 2,325 & 719 & 2,202 & 4,992 & 966 & 11,204 \\
\hline & Mixed geology & & & 212 & & & 5,104 \\
\hline & Basalt & 51 & 219 & 954 & 11,722 & & 12,946 \\
\hline & Gypsiferous & 518 & & 1,756 & & & 2,274 \\
\hline & Sedimentary & 58 & 2,644 & 3,173 & 7,430 & 1,073 & 14,377 \\
\hline \multirow[t]{5}{*}{ Medium slopes $\left(8^{\circ}\right.$ to $\left.19.5^{\circ}\right)$} & & 11,589 & 6,580 & 14,938 & 5,344 & 43 & 38,495 \\
\hline & Mixed geology & 6,993 & & & & & 6,993 \\
\hline & Basalt & 53 & 586 & 902 & 1,880 & & 3,422 \\
\hline & Gypsiferous & 476 & & 543 & & & 1,019 \\
\hline & Sedimentary & 349 & 1,815 & 6,194 & 2,288 & 39 & 10,685 \\
\hline Steep slopes $\left(>19.5^{\circ}\right)$ & & 3,718 & 4,178 & 7,299 & 1,176 & 4 & 16,375 \\
\hline Total & & 19,432 & 10,161 & 23,236 & 29,489 & 2,082 & 84,400 \\
\hline
\end{tabular}

${ }^{1} 030 \mathrm{X}$, Mohave Basin and Range, elevations range from 400 to 3,000 feet and precipitation averages 6 to 10 inches per year.

${ }^{2} 035 \mathrm{C}$, Colorado Plateau, elevations range from 4,500 to 6,000 feet and precipitation averages 10 to 14 inches.

${ }^{3} 035 \mathrm{E}$, Colorado Plateau, elevations range from 1,600 to 4,500 feet and precipitation averages 6 to 10 inches per year.

${ }^{4} 035 \mathrm{~F}$, Colorado Plateau, elevations range from 5,500 to 7,000 feet and precipitation averages 13 to 17 inches per year.

${ }^{5} 035 \mathrm{H}$, Colorado Plateau, elevations range from 6,800 to 8,500 feet and precipitation averages 17 to 25 inches per year.
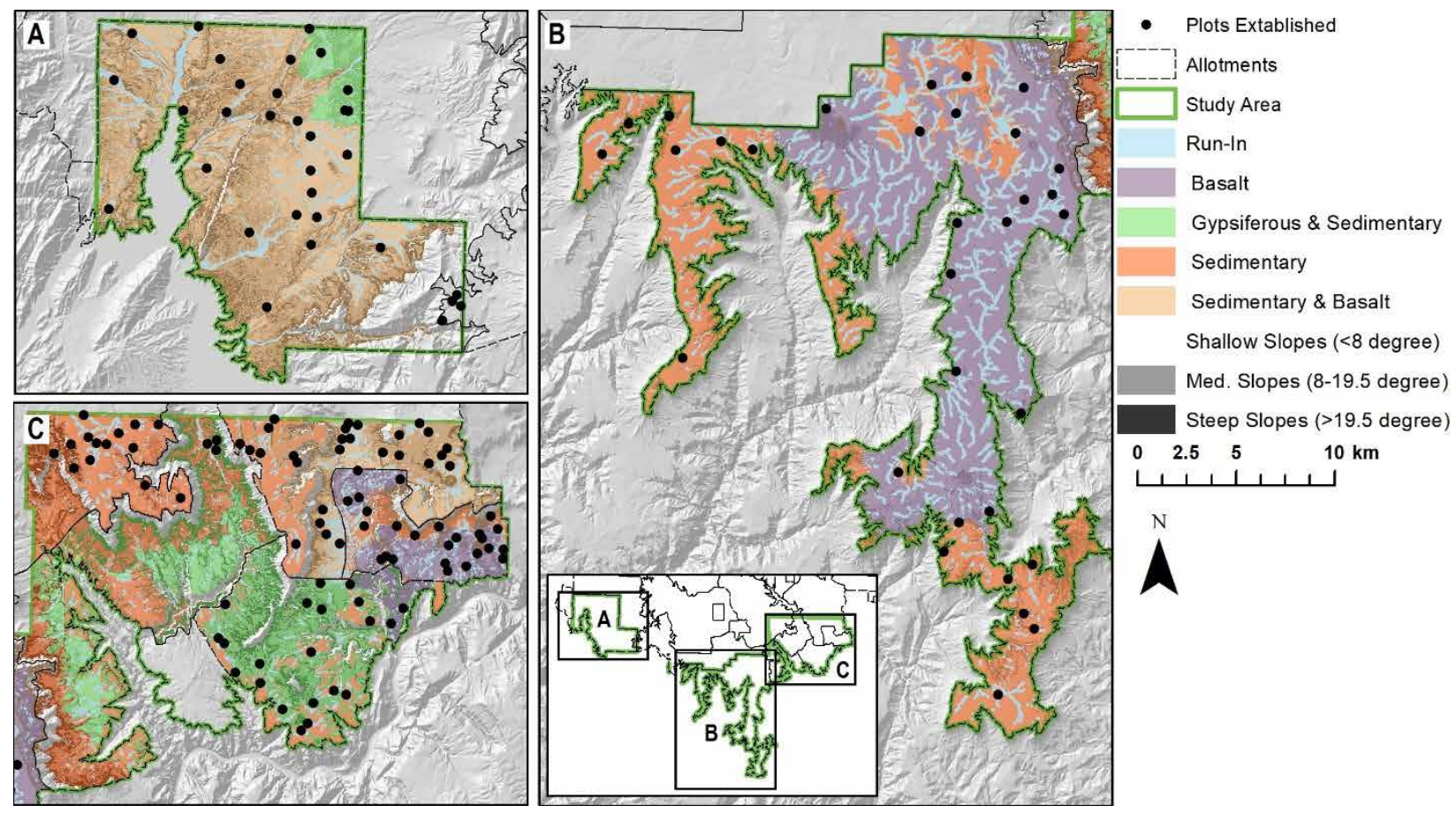

Figure 4. Maps of soil-geomorphic strata used for locating plots in the study area (locations sampled indicated by black dots). The geologic parent material classes were based on soil map unit descriptions and terrain subdivisions based on digital elevation model analyses. Map inset shows the part of the Grand Canyon-Parashant National Monument, northwestern Arizona, that the National Park System administers (outlined in green). km, kilometers. 
Table 4. Final distribution of plots sampled by allotment and topographic-geologic grouping.

\begin{tabular}{|c|c|c|c|c|c|c|c|c|c|}
\hline Topographic class & $\begin{array}{c}\text { Geologic parent } \\
\text { material }\end{array}$ & $\begin{array}{c}\text { Big Spring } \\
\text { Pipeline }\end{array}$ & $\begin{array}{l}\text { Home } \\
\text { Ranch }\end{array}$ & Mt. Trumbull & $\begin{array}{l}\text { Mule } \\
\text { Canyon }\end{array}$ & $\begin{array}{c}\text { Pa's } \\
\text { Pocket }\end{array}$ & $\begin{array}{l}\text { Red } \\
\text { Pond }\end{array}$ & Tassi & Total \\
\hline \multirow[t]{6}{*}{ Shallow slopes $\left(<8^{\circ}\right)$} & & 18 & 26 & 9 & 2 & 15 & 9 & 18 & 97 \\
\hline & Run-in & 7 & 10 & 4 & & 5 & 4 & 8 & 38 \\
\hline & Basalt & & 8 & & & 4 & & & 12 \\
\hline & Gypsiferous & & & & & & & 3 & 3 \\
\hline & Mixed & 11 & & & & 3 & & 7 & 21 \\
\hline & Sedimentary & & 8 & 5 & 2 & 3 & 5 & & 23 \\
\hline \multirow[t]{4}{*}{ Medium slopes $\left(8^{\circ}\right.$ to $\left.19.5^{\circ}\right)$} & & 7 & 5 & 3 & 1 & 8 & 4 & 6 & 34 \\
\hline & Basalt & & 2 & & & 2 & & & 4 \\
\hline & Mixed & 7 & & & & 3 & & 6 & 16 \\
\hline & Sedimentary & & 3 & 3 & 1 & 3 & 4 & & 14 \\
\hline Steep slopes $\left(>19.5^{\circ}\right)$ & & 2 & 1 & 2 & & 2 & 2 & 2 & 11 \\
\hline \multirow[t]{4}{*}{ Mixed slopes } & & & & 7 & & & & 6 & 13 \\
\hline & Basalt & & & 3 & & & & & 3 \\
\hline & Gypsiferous & & & 4 & & & & 2 & 6 \\
\hline & Middle bench & & & & & & & 4 & 4 \\
\hline Total & & 27 & 32 & 21 & 3 & 25 & 15 & 32 & 155 \\
\hline
\end{tabular}

our sample and to increase efficiency of field work. This was done because of the large size of each allotment (table 2) and the importance of landscape features and distance to water for governing cattle distribution in arid rangelands (Bailey and others, 1996). Distance to water was used as a proxy for likely grazing intensity and distance to accessible roads was used to estimate field sampling costs. For both distance to water and distance to roads, we created a cost-distance model that considered impassible cliffs and terrain steepness using the Spatial Analyst extension in ArcGIS. Cliffs were defined using a ruggedness index (Riley and others, 1999) where cells with ruggedness $>2.3$ were defined as impassible; for distance to water, allotment fence lines were defined as impassible. The monument is characterized by remote and rugged terrain. To increase efficiency of field work, we used the same travelcost surface as used for grazing intensity to calculate distance from roads for field sampling. For each strata within each study area allotment, we created one variable probability surface based on these two cost-distance models. The goal of the livestock cost-distance to water model was to increase the likelihood of obtaining samples from varying distances to water (even if those distances are not evenly represented on the landscape). This was achieved by binning the data for each strata and then making the selection probability inversely proportional to the area represented by each bin (scaled from $>0$ to $<1$ ). For the distance from roads probability, we scaled the cost-distance values for each strata from near zero (very far from roads) to near 1 (very near roads). These two probability surfaces were then averaged, and the final probability sampling surface represents a compromise between obtaining a grazing gradient and increasing field work efficiency (fig. 5).

\section{Vegetation and Soil Assessments}

A total of 155 plots were established and sampled between March and November of 2012 and 2013 (table 4, fig. 4). Mojave Desert sites were sampled in the early spring (March and April), high-elevation pinyon-juniper and ponderosa sites were sampled May through July, and the eastern canyon benches were sampled between August and October. Each 50 $\times 50-\mathrm{m}$ plot consists of three parallel $50-\mathrm{m}$ transects spaced $25 \mathrm{~m}$ apart. Transects were placed so that they followed the topography, with transects following topographic contours rather than running up or down slope. Plots were marked with blue painted rebar at each end of the center transect. The locations of all transect ends and the plot centers were recorded by Global Positioning System (GPS; Garmin eTrex, Vista HCx, accuracy $3 \mathrm{~m}$ ). Six plots intended for sampling were not established because the slopes were too steep to work on safely (four plots) or they were inaccessible (two plots). Only three plots were established in Parashant Canyon and no plots were established in Andrus Canyon and the surrounding benches (Mule Canyon and Dripping Spring allotments) because of extensive road damage during the sampling period in both 2012 and 2013. No plots were established in Lone Mountain owing to inaccessibility.

At each study plot, the NRCS soil map unit component was determined using soil properties and geomorphic setting (Lindsay and others, 2003). At a representative location near the plot center, a small soil pit or auger hole was excavated to a depth of at least 50 centimeters $(\mathrm{cm})$ in rocky soils and $100 \mathrm{~cm}$ in nonrocky soils or until a restrictive layer was reached. Soil pedogenic horizons were identified and described following Schoeneberger and others (2012). Soil properties descriptions 
include soil textural class, clay percentage, effervescence in response to 1 normal $\mathrm{HCl}$, coarse fragment content (percentage by volume), and carbonate stage. Structure (shape, grade, and size) was added in 2013 for horizons occurring within $\sim 30 \mathrm{~cm}$
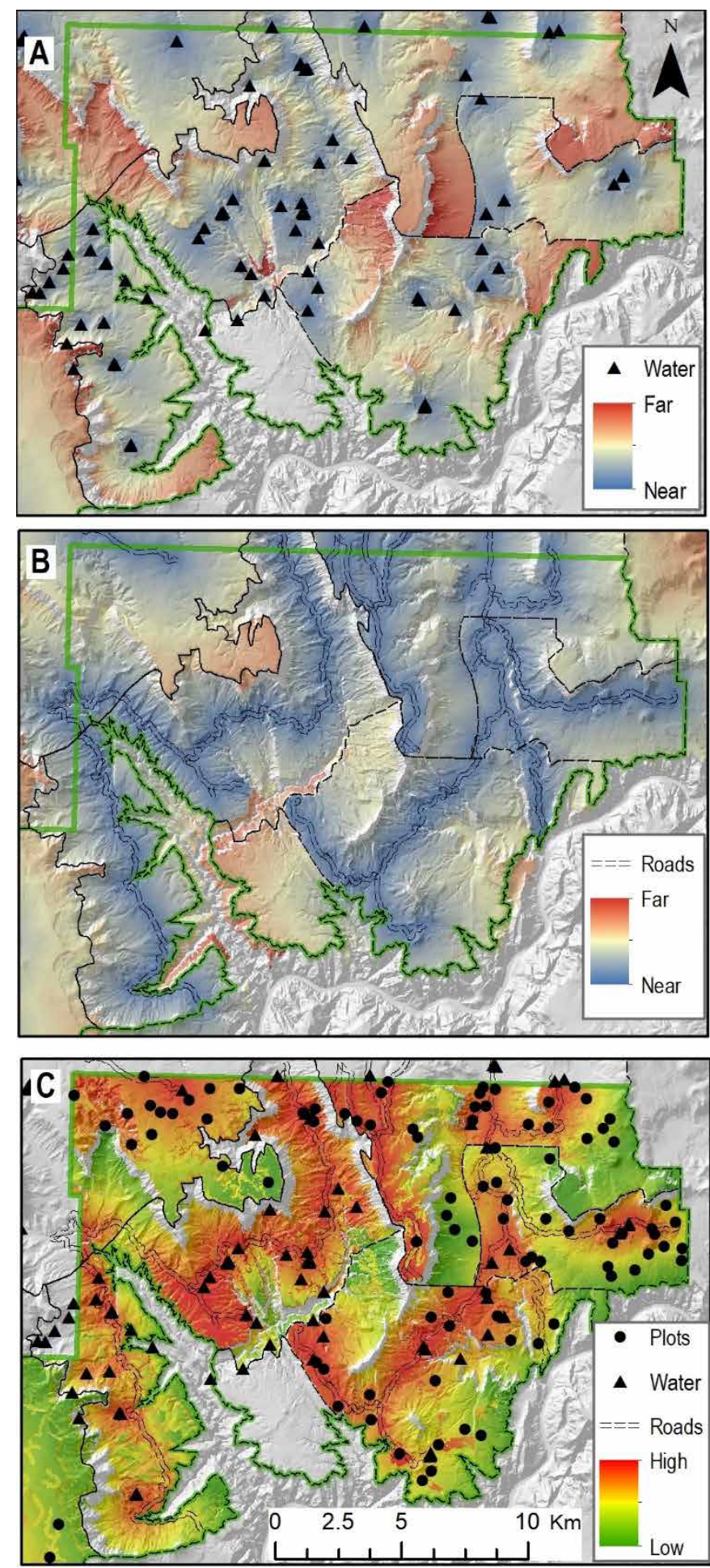

Figure 5. Maps showing example variable probability surfaces created for the eastern allotments in the study area in Grand Canyon-Parashant National Monument, northwestern Arizona,for $(A)$ distance to livestock water sources, $(B)$ distance from roads, and $(C)$ the final combined probability surface used in plot selection. of the soil surface. Plot parent material, landform, elevation, slope, slope shape, and aspect were also recorded. Additionally, digital photographs were taken at both ends of each transect following Herrick and others (2005) methods for a total of six photographs per plot. Each photograph contains a photograph board with the allotment, plot name, date, transect number, and direction of image.

We used soil and landscape property data, along with climate zone, and plot photographs to assign each plot to a soil map unit component (Lindsay and others, 2003). We did not restrict possible soils to those described for the map unit in which the plot occurred but included surrounding map units as well. We then identified the plot ecological site using the map unit component-ESD correlation provided in the NRCS soil survey database (Lindsay and others, 2003).

To assess plot ecological condition, we collected data on soil and site stability, hydrologic function, and plant community cover and composition. Foliar cover by species, ground cover, and plant composition were assessed using the line-point intercept method (LPI; Herrick and others, 2005) with a point spacing of $1 \mathrm{~m}$, for a total of 150 points per plot. Plant species frequency was assessed using a nested frequency frame containing a $10 \times 10 \mathrm{~cm}$ and $40 \times 40 \mathrm{~cm}$ quadrat (rooted frequency for herbaceous species and canopy frequency for woody species). Frames were placed every $5 \mathrm{~m}$ along each transect, resulting in 30 frames per plot. Potential for wind and water erosion, run-off, and perennial community structure were assessed on each transect using the perennial plant canopy and basal gap intercept method (Herrick and others, 2005). Surface soil aggregate stability was measured using a soil stability test, which ranks stability from 1 to 6 , with 6 being the most stable (Herrick and others, 2001; Herrick and others, 2005). Six soil surface samples were collected at randomly selected points along each transect (18 per plot). Relative cattle use was assessed using frequency of dung. The presence or absence of cattle dung was recorded for ten $1 \times 1-\mathrm{m}$ quadrats per transect (placed every $5 \mathrm{~m}, 30$ total per plot). It is not possible to use cattle dung frequency counts to estimate absolute use (Fuller, 1991), but dung counts have been used in many studies as an index of relative use (Augustine, 2003; Veblen, 2012; Kimuyu and others, 2017).

All soil and vegetation data were entered into the Database for Inventory, Monitoring, and Assessment (DIMA; Courtright and Van Zee, 2011) either directly using a field computer (LPI, canopy and basal gap) or afterward (soil stability, frequency, and soil pedon descriptions). Basic summary reports were generated in DIMA for further data analysis. Dung frequency data were entered and stored separately.

\section{Data Analyses}

We used four general approaches to data analysis. First, we provide general descriptions and summaries of soils, plants, and cattle activity across the Grand Canyon-Parashant National Monument. Second, we summarized quantitative indicators of rangeland health (table 1) by generalized ecological site type and then conducted analyses for differences in indictors 
between these soil groups. Third, within the four climate zones, we conducted community-scale analyses using multivariate approaches to understand how plot soil and plant composition vary across the landscape, looking for natural floristic groups. Fourth, we examined the univariate and multivariate data for the relations among indicators of rangeland health, abiotic gradients, and indicators of cattle activity.

Plot-level averages of species foliar cover, soil cover, plant canopy and basal gap distribution, and other indicators of rangeland health were derived using the reporting functions provided by DIMA (table 1; Courtright and Van Zee, 2011). Plant species were categorized in three ways: growth form (tree, shrub, grass, or forb), woody or herbaceous, and perennial or annual. Category determinations follow the U.S. Department of Agriculture PLANTS database. For species that can take on multiple growth forms (for example, can either be a forb or subshrub), the form that was most commonly seen in the study area was used. These categories were used to broadly describe plant structure. Although frequency was collected for all plant species, we only analyzed frequency of exotic species here. Species lists with associated classifications and all frequency data is available in Duniway and Palmquist (2020).

Trends in rangeland ecosystem indicators with elevation were examined using cubic local regression (SAS software ver. 9.4, LOESS procedure). Relations between cattle dung frequency and environmental covariates were examined using a quantile regression approach (QUANTREG procedure). Quantile regression provides an approach for examining relations between independent and dependent variables that is robust to outliers (Cade and Noon, 2003). A final index of relative cattle use was developed based on a multiple quantile regression using frequency of cattle dung (dependent variable) and a suite of environmental covariates (independent variables). Environmental covariates examined included cost-distance to water (as described in the survey design), plot ruggedness (using the ruggedness index described above), and soil survey estimated forage production (representative value) for the correlated soil map unit component. Forage production is an attribute in NRCS soil surveys based on soil profile properties and climate that can be used to estimate appropriate stocking rates.

We created site climate zones based on NRCS precipitation groups and natural elevation breaks and grouped ESDs in each climate zone into generalized ecological site groups (ESGs) based on similarity in soil properties and (or) soil parent materials (fig. 6; Duniway and others, 2016). Descriptive statistics of plant and soil communities were done using SAS ver. 9.4 (MEANS procedure) and examination of differences in indicators was done using a mixed model with ESGs as fixed effects (MIXED procedure).

To conduct multivariate analyses, two data matrices were created from plot data in each of the four climate zones, one containing the foliar and ground cover data and the other environmental and cattle use variables. The foliar and ground cover data matrices were used for the cluster and multivariate analyses, and the environmental and cattle use matrices were used to examine correlations. The foliar and ground cover matrices consisted of the cover values for each plant species, biological soil crust, litter, and bare soil, as well as frequency values instead of LPI cover values for Bromus rubens, Bromus tectorum, Erodium cicutarium, and Schimus arabicus. Frequency values were used for these four nonnative invasive species because their cover values were commonly low but their presence or absence was considered an important indicator of ecosystem change. The correlation matrices consisted of the physical characteristics of the plot (slope, aspect, and elevation), characteristics of the soil (parent material, percentage of cover by rock fragments on the surface, percentage of rock by volume of the first horizon, surface texture, and percentage of sand and silt estimates), cattle dung frequency, the cattle use index, and distance to the nearest road (table 5).

Multivariate analyses, richness, and diversity measures (Simpson's diversity index and Shannon's diversity index) were generated using PC-ORD ver. 6.08 (McCune and Mefford, 2011). Both measures of diversity are reported here to facilitate comparisons across geographic regions and studies. Prior to multivariate analysis, species that occurred in less than 5 percent of plots were removed (McCune and Grace, 2002). Cover values were converted to compositional cover (cover of species within the total foliar cover) for all species other than the four nonnative species listed above. Data was otherwise untransformed, except where transformation clarified relations. In the one case where data transformation improved analyses (middle desert), a square root transformation was applied to all columns. Two plots were removed from analyses for which outlier analysis using the Sørensen distance measure indicated that they fell more than two standard deviations from the mean and including these outliers obscured further interpretation of data. One of these outliers occurs in a burned ponderosa forest, which now has very little living ponderosa overstory and has high amounts of very large woody material owing to dead and downed ponderosa. The other outlier occurs in a drainage through bedrock with very little soil and consequently very little foliar cover.

Plots were classified using hierarchical cluster analysis (flexible beta $[\beta=-0.25]$ linkage and a Sørensen distance matrix) and indicator species analysis $(9,999$ randomizations and quantitative response). The number of clusters that generated the highest indicator values and had a reasonable amount of information remaining was chosen to define floristic groups. Those groups were also cross-checked with plot photographs to make sure the communities were recognizable.

Nonmetric multidimensional scaling (NMS) using the Sørensen distance measure was used to illustrate variability within climate zones and correlations between floristic groups and explanatory variables (environmental and land use factors). The "slow and thorough" method in autopilot was chosen, which uses a random starting configuration, 250 runs of real and randomized data with a maximum of 500 iterations, and an instability criterion of 0.0000001 . The best 

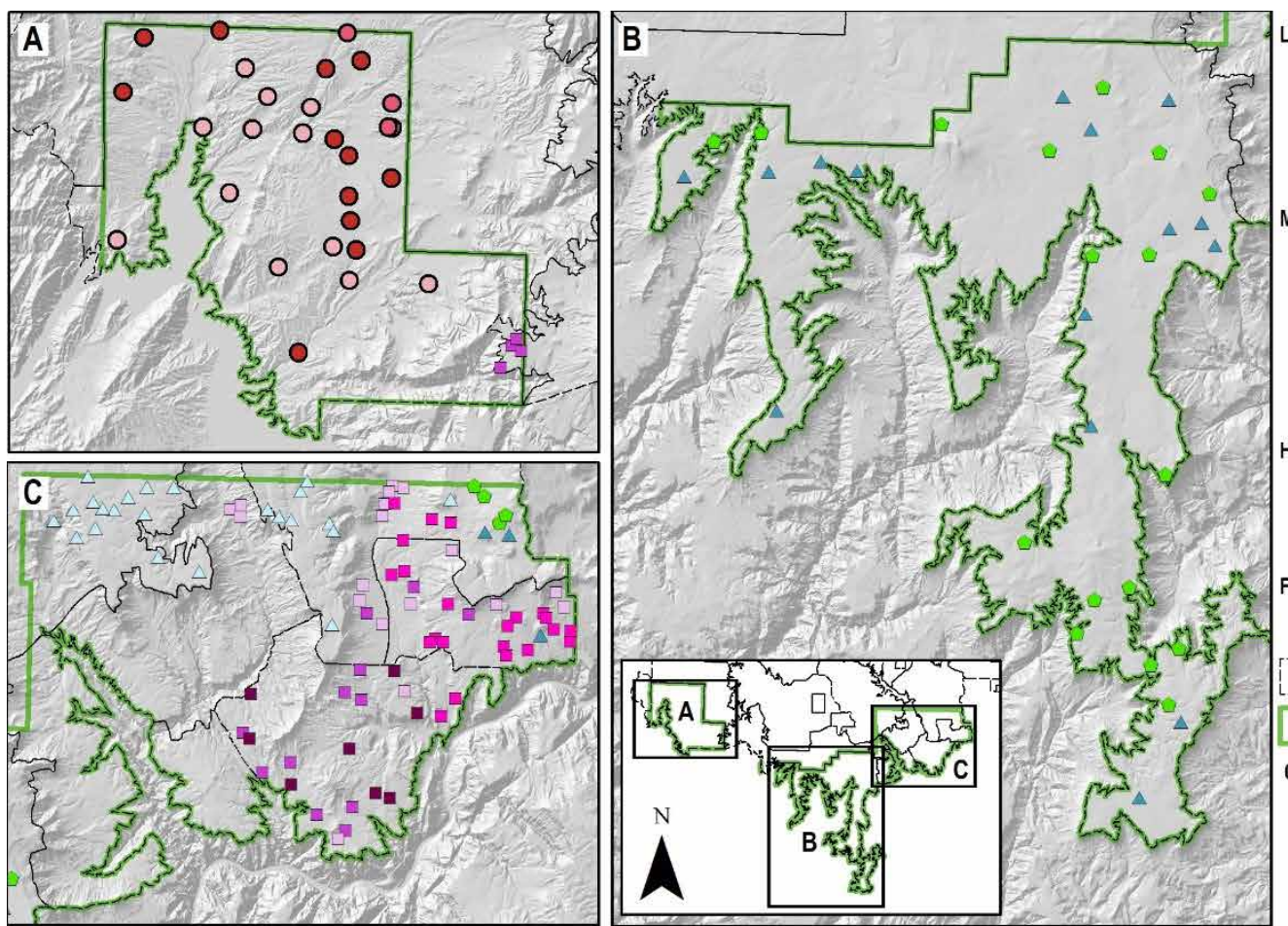

Low Desert

O $\mathrm{H}$-Shallow Limestone

- G-Deep Mixed

O C-Gypsum

Middle Desert

- I-Shallow Mixed

- I J-Deep Limestone

- A-Deep Basalt

- E-Shallow Sandstone

High Desert

$\Delta \quad$ D- Deep Basalt

$\triangle \quad F$ - Shallow Limestone

Forest \& Savanna

- B-Shallow Loam

Allotments

Study Area

$\begin{array}{lll}0 & 2.5 & 5\end{array}$

$10 \mathrm{~km}$

Figure 6. Maps showing the distribution of identified ecological site groups (table 6). Map inset shows the part of the Grand Canyon-Parashant National Monument, northwestern Arizona, that the National Park System administers (outlined in green). km, kilometers.

Table 5. Landscape setting, soil, and cattle use variables hypothesized to control indicators of rangeland health and community ordinations in the Grand Canyon-Parashant National Monument, northwestern Arizona.

$\left[\mathrm{m}^{2}\right.$, square meters; $\mathrm{Wm}^{-2}$, watts per square meter]

\begin{tabular}{|c|c|c|}
\hline Variable & Description & Source $^{1}$ \\
\hline \multicolumn{3}{|c|}{ Landscape setting } \\
\hline Elevation & Plot elevation, in meters & DEM \\
\hline TWI & Topographic wetness index (Sörensen and others, 2006) & DEM \\
\hline Flow accumulation & Contributing area, measure of hydrologic connectivity (log transformed) & DEM \\
\hline Slope & Plot average slope (degrees) & DEM \\
\hline Curvature & Plot compound curvature & DEM \\
\hline Solar insolation & Plot annual solar insolation (in $\mathrm{Wm}^{-2}$ ) & DEM \\
\hline \multicolumn{3}{|c|}{ Soil surface properties } \\
\hline Bedrock & Cover of exposed bedrock & LPI \\
\hline Cobble & Cover of surface cobbles & LPI \\
\hline Gravel & Cover of surface gravels & LPI \\
\hline All Rock & Total rock cover & LPI \\
\hline A-horizon fragment & Rock fragments in surface soil horizon A & Soil \\
\hline Sand & Estimated sand content of surface horizon & Soil \\
\hline Clay & Estimated clay content of surface horizon & Soil \\
\hline Saturated conductivity & Saturated conductivity of surface horizon based on texture & Soil \\
\hline AWC & Available water capacity of surface horizon based on texture & Soil \\
\hline Field cap. & Field capacity of surface horizon based on texture & Soil \\
\hline
\end{tabular}


Table 5. Landscape setting, soil, and cattle use variables hypothesized to control indicators of rangeland health and community ordinations in the Grand Canyon-Parashant National Monument, northwestern Arizona.-Continued.

\begin{tabular}{|c|c|c|}
\hline Variable & Description & Source \\
\hline \multicolumn{3}{|c|}{ Cattle } \\
\hline Cow dung & Frequency of cow dung in $1-\mathrm{m}^{2}$ quadrats & Freq. \\
\hline Distance to water & Cost-distance to water source (log transformed) & Derived \\
\hline Cattle index & Cattle index based on multiple quantile regression & Derived \\
\hline \multicolumn{3}{|c|}{\begin{tabular}{|c|} 
Soil classes \\
\end{tabular}} \\
\hline Depth & Generalized soil depth class (very shallow, shallow, and moderately deep or deeper) & Soil \\
\hline Texture & Generalized soil textural class & Soil \\
\hline Soil taxonomy & Generalized soil taxonomic class & Soil \\
\hline
\end{tabular}

${ }^{1}$ DEM, calculated from 10-meter digital elevation model; LPI, line-point intercept model; Soil, data from soil pedon observation or derived soil variable (using pedotransfer function or soil survey; Schapp and others, 2001); Freq., quadrat frequency data; Derived, variable calculated using multiple sources (see Materials and Methods section).

number of dimensions was assessed by substantial reductions in stress and a Monte Carlo test (McCune and Grace, 2002). Pearson's $r$ was used to analyze correlations between axis scores and explanatory variables.

To examine for structure in the cross-tabulation of ESGs and floristic groups, chi-square tests were done by climate zone (SAS ver. 9.4; FREQ procedure). Analysis of association between rangeland health indicators, NMS axis, and edaphic explanatory variables were done by climate zone using correlation for continuous variables (SAS ver. 9.4; CORR procedure) and mixed model analysis of variance for class variables (MIXED procedure). Edaphic variables included DEM-derived landscape setting indices, surface soil rockiness indicators, soil texture, and estimates of soil hydrologic properties (table 5; Schaap and others, 2001). The various field data as well as new data generated using geographic information systems and statistical analysis are available in Duniway and Palmquist (2020).

\section{Results}

\section{Soils, Ecological Sites, and Vegetation Communities Sampled}

In the 155 plots, we sampled 15 unique soil taxa (to great group level) and 52 unique soil map units components (table 6). Soil taxa represented in the plot data are dominated by aridisols but include mollisols and alfisols at high elevations, entisols in active alluvial settings, and some vertisols in locations dominated by shrink-swell clays. These 52 soil map unit components were correlated to 31 unique ecological sites in the soil survey (Lindsay and others, 2003). We used the NRCS MLRA and CRA classifications (primarily delineated by elevation breaks) as an initial ecological site grouping factor. We then looked within these groups for similarities in soil parent material, slope, and texture to develop potential soil-geomorphic units that will share commonalities in soil-plant relations. This resulted in a total of ten ESGs that were distributed among four climate zones (table 6); three in the low desert, four in the middle desert, two in the high desert, and one in the forest and savanna climate zones (fig. 6).

A total of 271 species were recorded in the study area (based on nested frequency and LPI). This includes new vouchered collections of three species for Grand CanyonParashant National Monument and 17 species for the NPSadministered part of the monument. All collections are located at the Grand Canyon-Parashant National Monument Herbarium. The new species recorded and vouchered for Grand Canyon-Parashant National Monument are Eriastrum sparsiflorum, Thlaspi montanum, and Trichoptilium incisum. Cluster analysis and indicator species analysis identified a total of 11 different floristic groups (table 7) distributed among the four climate zones (fig. 7). Details of cluster analysis and ordination results are provided by climate zone below.

Cross tabulation of plot tallies by the ESGs assigned a priori and data-driven cluster analysis of vegetation composition suggests a strong concordance between the two approaches in most instances (table 8), indicating close links between soils and vegetation. Notable exceptions include the splitting of the Mojave shrub, desert grassland, and blackbrush floristic groups into two primary ESGs and some significant spread among floristic groups within the deep basalt, shallow limestone, and shallow loam ESGs. Details of the underlying properties driving these results are given by climate zone. 


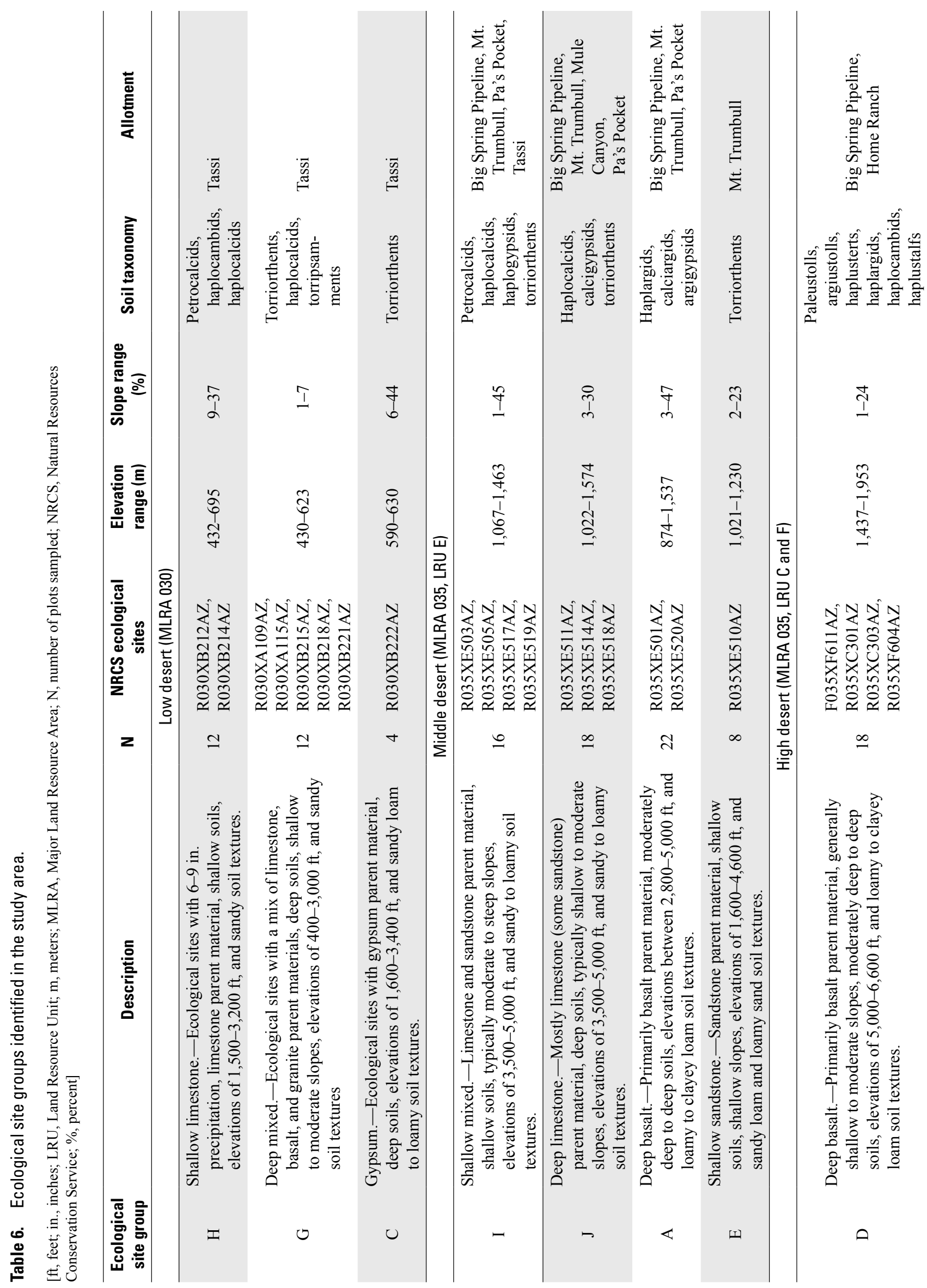



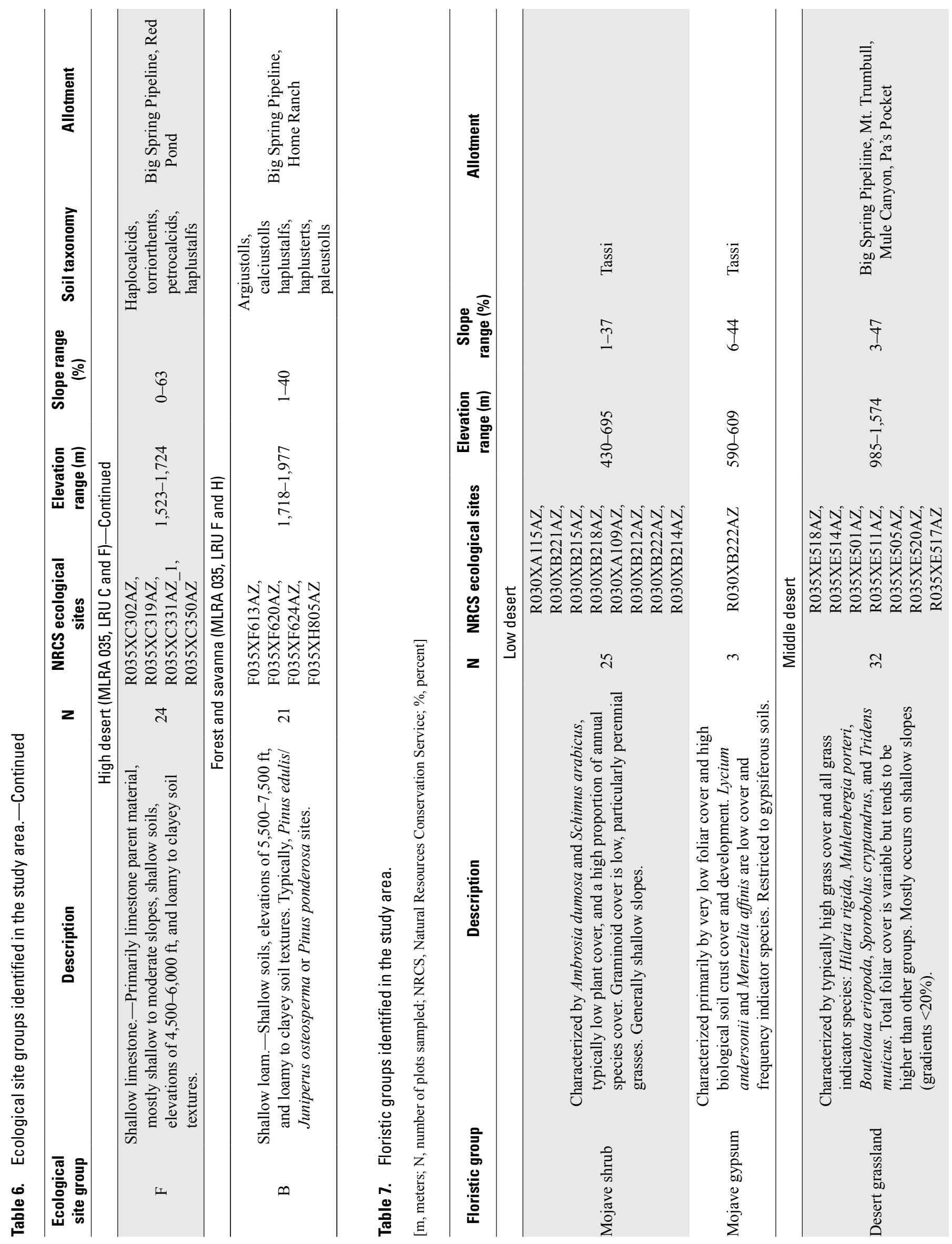


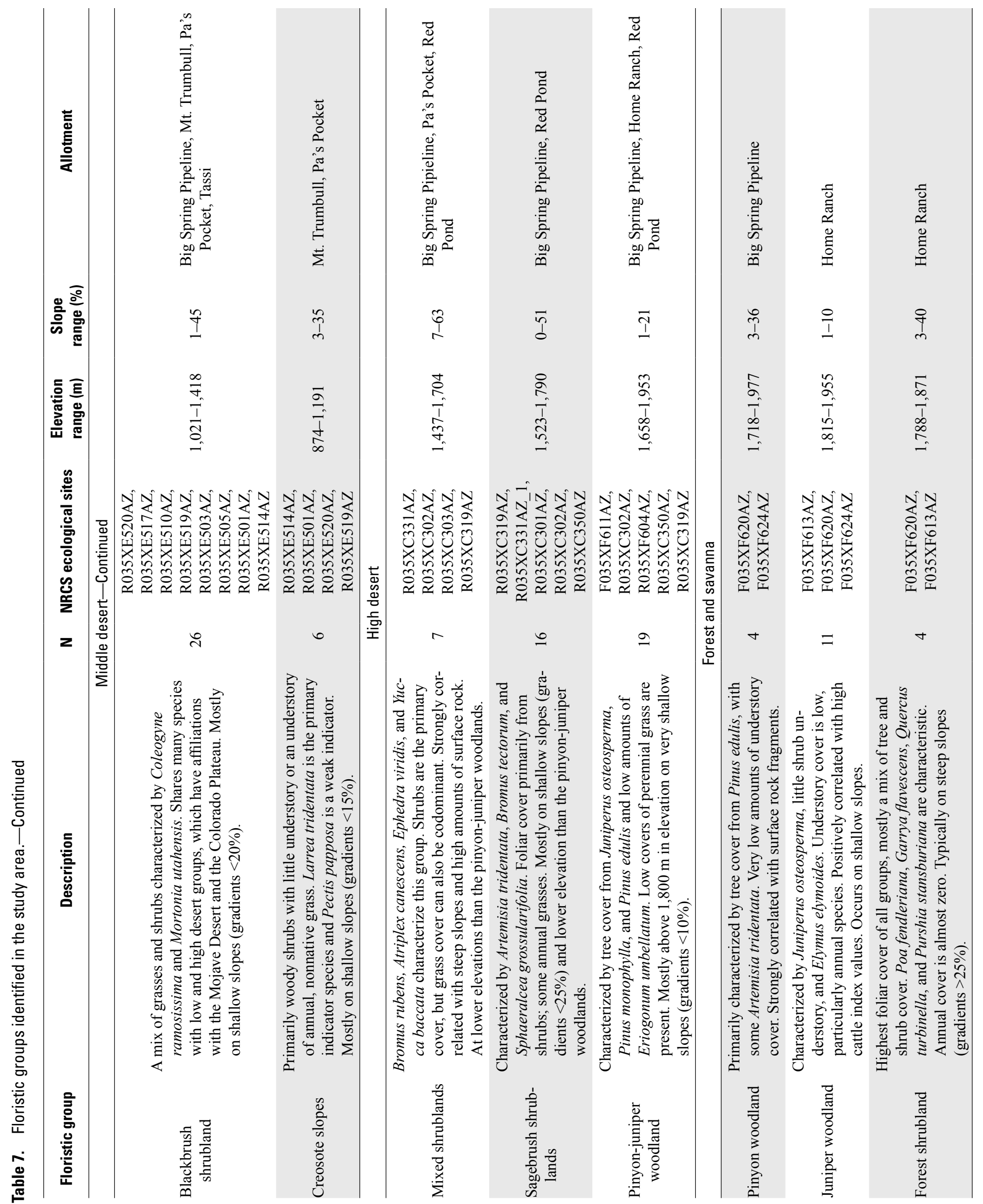




\section{Trends Across Elevation}

Indicators of soil and site stability and hydrologic function show contrasting trends with elevation (fig. 8). Vegetation gap indicators signify increasing stability and function (decrease in cover of large basal and canopy gaps and increase in protective litter cover) with increasing elevation, and total amount of exposed bare soil is generally unchanged across elevations (fig. 8A). There is a large increase in litter cover between 1,700 and $1,800 \mathrm{~m}$, likely associated with an increase in tree cover (fig. $8 \mathrm{~A}$ ). Soil surface biologic indicators (biological soil crusts and soil aggregate stability) show a decrease with elevation whereas rock cover increases slightly to a peak between 1,400 and 1,500 $\mathrm{m}$ before reaching lower values at higher elevations (fig. $8 B$ ). The average aggregate soil stability index is highest in the low elevations (ca. 4), with a pronounced dip in soil aggregate stability to minimum smoothed index value of ca. 2 near $1,700 \mathrm{~m}$. Total biological soil crust cover decreases between the low-elevation Tassi allotment and the next elevation zone with data $(1,100 \mathrm{~m})$.

Trends in indicators of biotic integrity demonstrate the importance of elevation (and associated climates) on plant communities in Grand Canyon-Parashant National Monument (fig. 9). Plant diversity is highest in the lower and upper reaches of the study area (table 9), with an evident dip in the local regression line and many field plots that have very low diversity between 1,000 and 1,400 m elevation (fig. 9A). Average total foliar cover increases with increasing elevation; the lowest cover value is for the low desert zone (ca. 0.2) and the highest is for the forest and savanna zone (ca. 0.5).
Understory herbaceous and shrub cover peaks at the boundary between the low and high desert elevations (1,400-1,500 m), which coincides with marked increase in tree cover (starting at ca. 1,600 m; fig. 9A). Trends in dominant woody species cover with elevation show both elevation distinction and overlap among species (fig. 9B). Ambrosia dumosa and Larrea tridentata are both dominants in the lowest elevations and L. tridentata occurs at high cover values as high as about 1,200 m, whereas A. dumosa is limited to elevations below $700 \mathrm{~m}$. Coleogyne ramosissima and Ephedra spp. overlap in elevation with $L$. tridentata, with average cover peaking at ca. 1,400 and 1,500 m, respectively. Artemisia spp. cover begins at ca. $1,400 \mathrm{~m}$, peaks at ca. $1,600 \mathrm{~m}$, and decreases at higher elevations. For the common tree species, Juniperus spp. and pinyon, cover starts at 1,500 and 1,600 m, respectively. Juniperus spp. are the dominant species at high elevations, with a sharp increase in cover between 1,700 and 1,800 m.

Occurrence of invasive species is an important part of biotic integrity, and frequency of invasive species of concern shows strong trends with elevation (fig. 9C). The annual grass Bromus rubens is the most common invasive species at most elevations. Schismus arabicus, also an annual grass, has similar, if not higher, frequency in the lowest elevations but observations of this species were infrequent above $700 \mathrm{~m}$. The biennial forb Erodium cicutarium, a nonnative weed, occurs at low to mid-elevations (500-1,600 m). Average frequencies are low (local area regression line), but there are several plots across elevations that have high frequency. Bromus tectorum, another regionally important annual invasive grass, is also prevalent in the high elevation sites (1,400 to $1,900 \mathrm{~m})$.
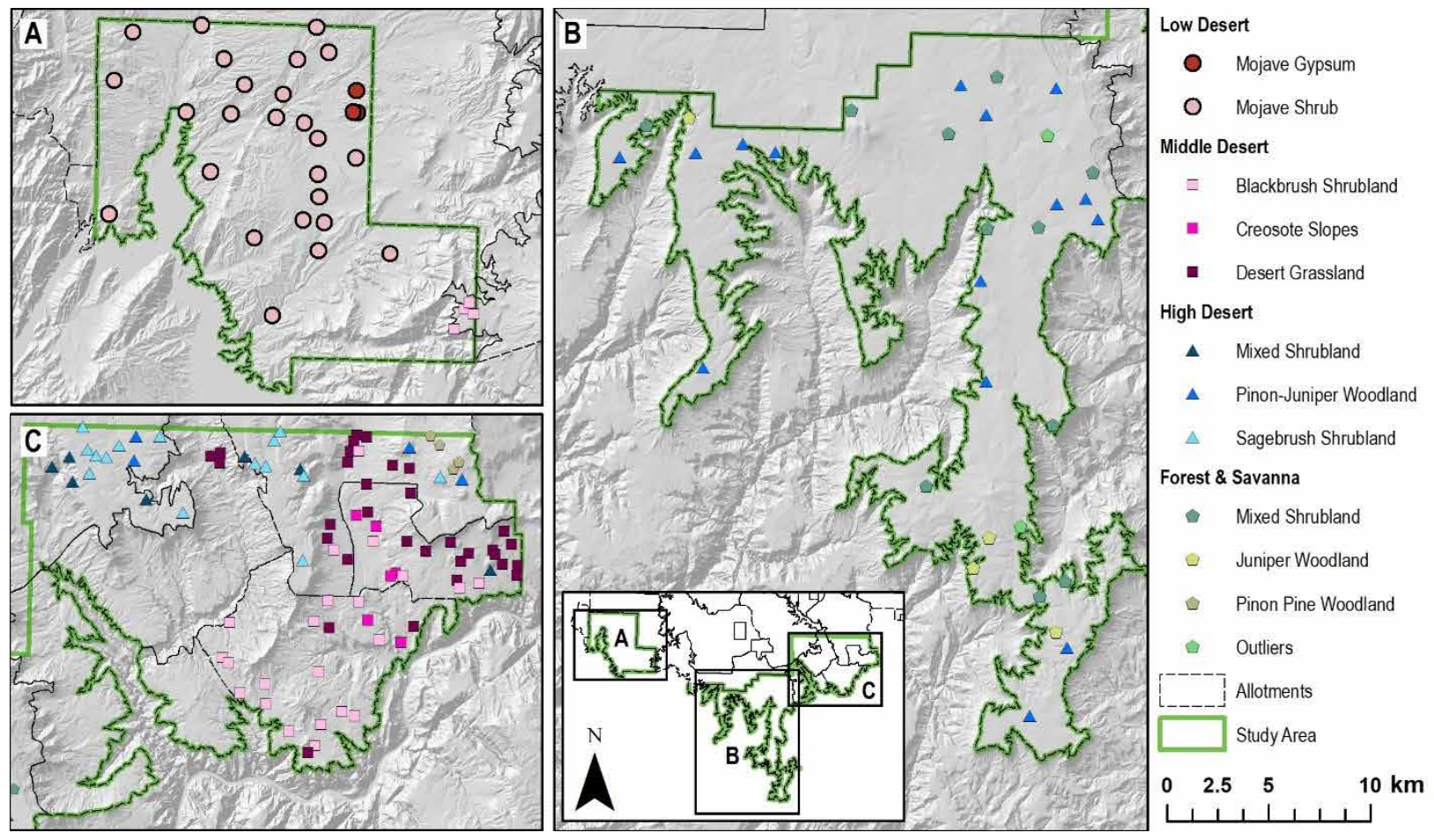

Figure 7. Maps showing the spatial distribution of identified floristic groups (table 7). Map inset shows the part of the Grand Canyon-Parashant National Monument, northwestern Arizona, that the National Park System administers (outlined in green). km, kilometers. 
Table 8. Cross tabulation of ecological site groups (ESGs) (fig. 6) and cluster analysis floristic groups (fig. 7).

[Values are number of plots in each combination of ESGs and floristic groups. ESG and cluster groups show significant association (chi-square test for independence in all climate zones except forest and savanna, where there is only one ESG). Low desert $p=0.001$, middle desert $p<0.001$, and high desert $p<0.001]$

\begin{tabular}{|c|c|c|c|c|c|c|c|c|c|c|}
\hline \multirow{2}{*}{ Cluster analysis floristic groups } & \multicolumn{3}{|c|}{ Low desert } & \multicolumn{4}{|c|}{ Middle desert } & \multicolumn{2}{|c|}{ High desert } & \multirow{2}{*}{$\begin{array}{c}\begin{array}{c}\text { Forest and } \\
\text { savanna }\end{array} \\
\text { B }\end{array}$} \\
\hline & C & G & H & A & $\mathbf{E}$ & I & $\mathbf{J}$ & D & $\mathbf{F}$ & \\
\hline Mojave shrub & 1 & 12 & 12 & & & & & & & \\
\hline Mojave gypsum & 3 & & & & & & & & & \\
\hline Desert grassland & & & & 14 & & 2 & 16 & & & \\
\hline Blackbrush shrubland & & & & 4 & 8 & 13 & 1 & & & \\
\hline Creosote slopes & & & & 4 & & 1 & 1 & & & \\
\hline Mixed shrublands & & & & & & & & 1 & 6 & \\
\hline Sagebrush shrublands & & & & & & & & 1 & 15 & \\
\hline Pinyon-juniper woodland & & & & & & & & 16 & 3 & \\
\hline Pinyon woodland & & & & & & & & & & 4 \\
\hline Juniper woodland & & & & & & & & & & 11 \\
\hline Forest shrubland & & & & & & & & & & 4 \\
\hline Outliers & & & & & & & & & & 2 \\
\hline
\end{tabular}
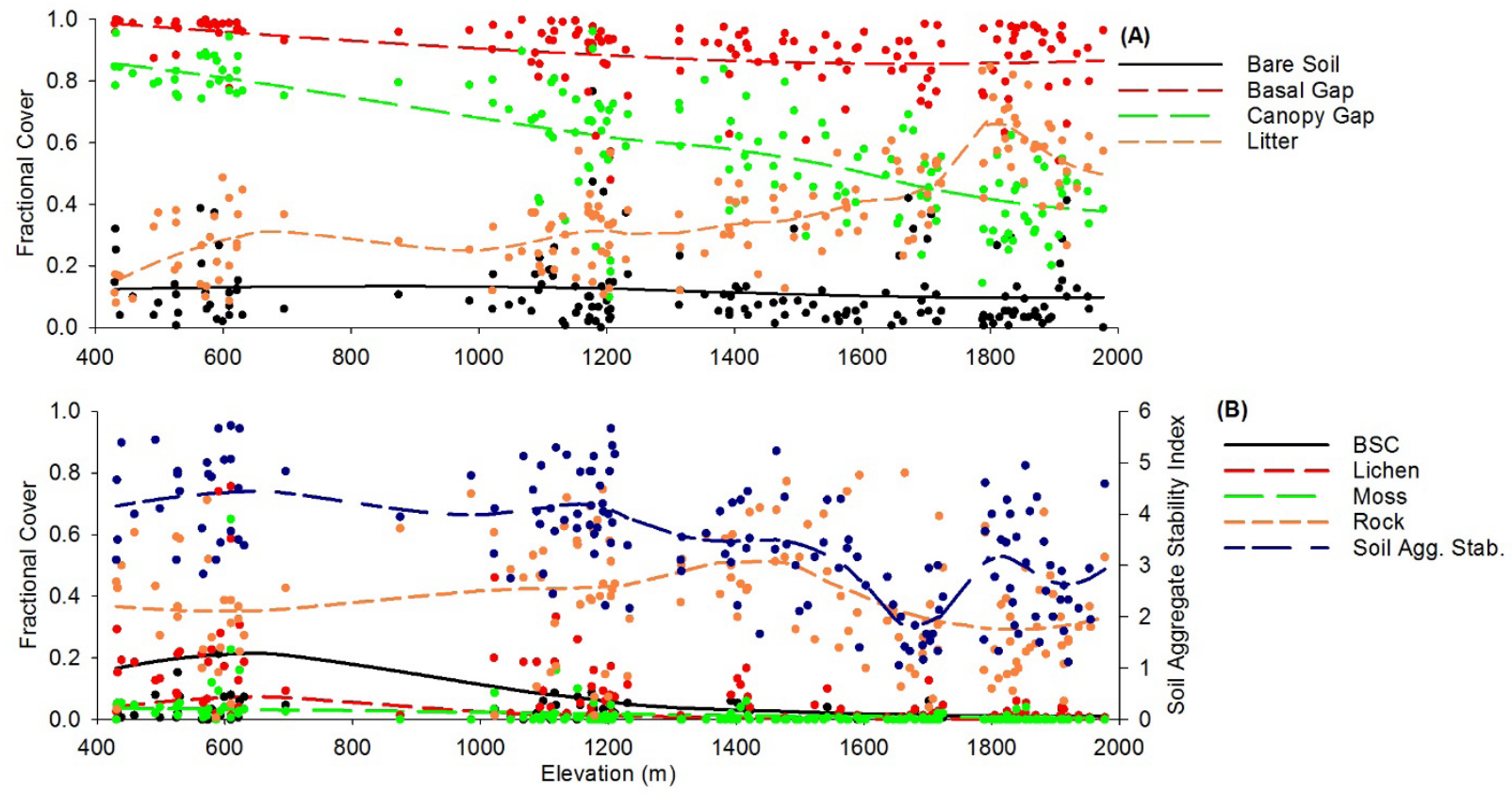

Figure 8. Plots showing trends in indicators of $(A)$ soil and site stability and $(B)$ hydrologic function with elevation (in meters [m]). Dots are observations, lines are loess cubic fit (SAS ver. 9.4, LOESS procedure). Plot $A$ shows cover of bare soil, proportion of large basal (>200 centimeters [cm]) and canopy $(>100 \mathrm{~cm}$ ) gaps, and cover of litter (herbaceous and woody). Plot $B$ shows indicators of soil cover, total biological crust cover (BSC), lichen cover, moss cover, rock cover, and soil aggregate stability. 


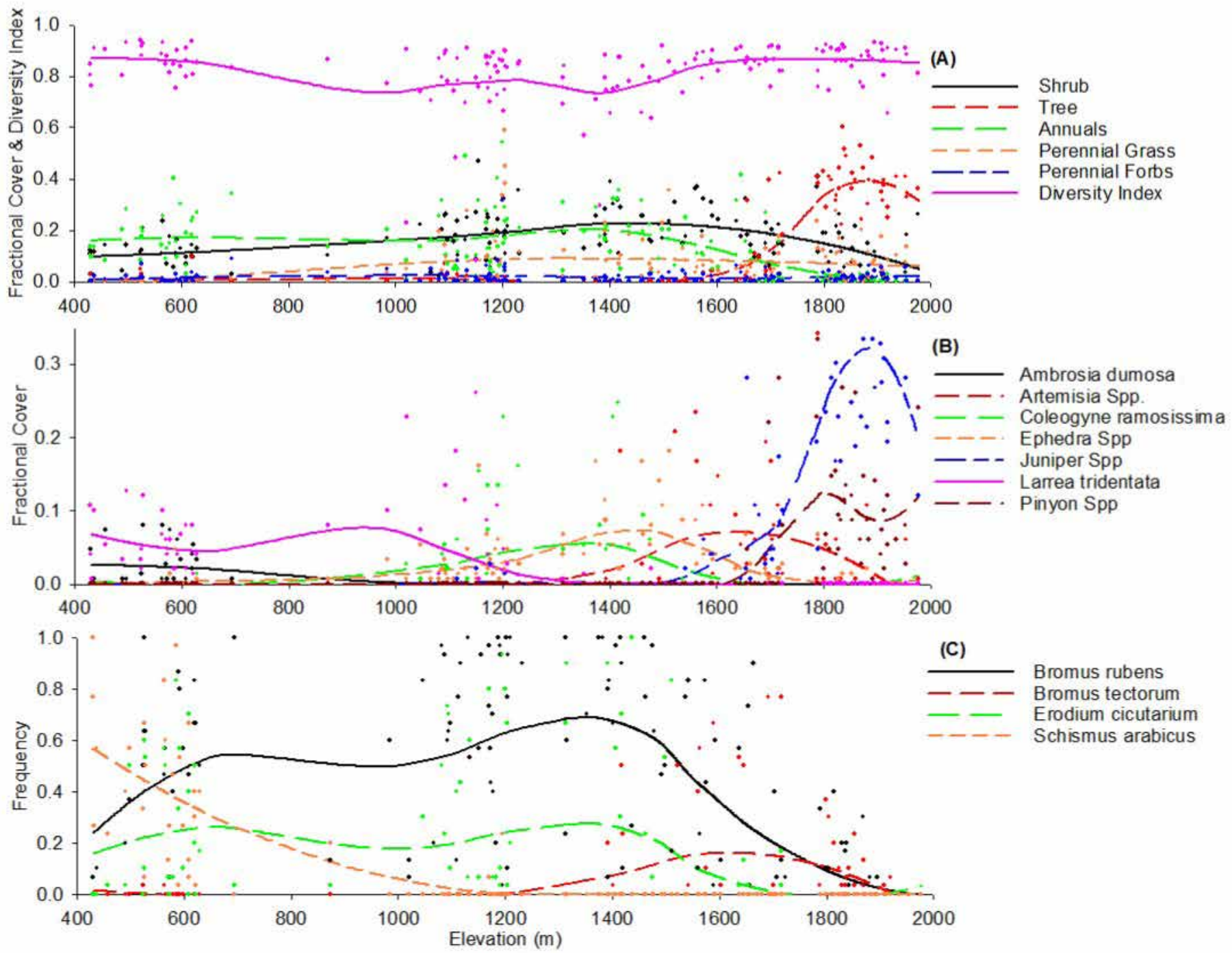

Figure 9. Plots showing trends in indicators of biotic integrity with elevation (in meters [m]). Dots are observations, lines are loess cubic fit (SAS ver. 9.4, LOESS procedure). $A$, Shrub cover, tree cover, annual cover, perennial grass cover, perennial forb cover, and Simpson's diversity index. $B$, Cover of dominant woody species. $C$, Frequency of invasive species (using a 0.16 square meter frame).

Table 9. Richness and diversity indices for climate zones and floristic groups within.

\begin{tabular}{lcccc}
\hline \multicolumn{1}{c}{ Floristic group } & $\begin{array}{c}\text { Avg. number of } \\
\text { species per plot }\end{array}$ & $\begin{array}{c}\text { Total number of species } \\
\text { recorded }\end{array}$ & $\begin{array}{c}\text { Avg. Simpson's } \\
\text { diversity index }\end{array}$ & $\begin{array}{c}\text { Avg. Shannon's } \\
\text { diversity index }\end{array}$ \\
\hline Low desert & 10.3 & 62 & 0.78 & 1.85 \\
Mojave shrub & 10.6 & 56 & 0.78 & 1.87 \\
Mojave gypsum & 7.7 & 17 & 0.76 & 1.68 \\
Middle desert & 11.1 & 107 & 0.75 & 1.81 \\
Desert grassland & 13.2 & 84 & 0.81 & 2.03 \\
Blackbrush shrubland & 9.5 & 65 & 0.74 & 1.70 \\
Creosote slopes & 6.8 & 19 & 0.52 & 1.12 \\
High desert & 11.0 & 82 & 0.70 & 1.68 \\
Mixed shrublands & 15.7 & 52 & 0.84 & 2.25 \\
Sagebrush shrublands & 10.6 & 37 & 0.74 & 1.74 \\
Pinyon-juniper woodland & 9.7 & 41 & 0.62 & 1.42 \\
\hline
\end{tabular}


Table 9. Richness and diversity indices for climate zones and floristic groups within.-Continued

\begin{tabular}{ccccc}
\hline Floristic group & $\begin{array}{c}\text { Avg. number of } \\
\text { species per plot }\end{array}$ & $\begin{array}{c}\text { Total number of species } \\
\text { recorded }\end{array}$ & $\begin{array}{c}\text { Avg. Simpson's } \\
\text { diversity index }\end{array}$ & $\begin{array}{c}\text { Avg. Shannon's } \\
\text { diversity index }\end{array}$ \\
\hline Forest and savanna & 10.9 & 51 & 0.69 & 1.61 \\
Pinyon woodland & 7.2 & 14 & 0.65 & 1.36 \\
Juniper woodland & 11.2 & 36 & 0.64 & 1.50 \\
Forest shrubland & 12.2 & 22 & 0.82 & 1.97 \\
\hline
\end{tabular}

\section{Cattle Use}

Comparison of cow dung frequency to cost-distance from water in active grazing allotments indicates factors other than distance to water are also important for determining cattle distribution within NPS-managed allotments in Grand Canyon-Parashant National Monument (fig. 10A). Looking at the relation between cattle dung frequency and cost-distance to water, we observed a generally better fit to the upper quantiles of the dung frequency distribution (log-linear; $p=0.003 ; 90$ th percentile better than 75 th or 50th), which suggests that the cost-distance to water variable provides a robust estimate of the upper bound on cattle dung frequency and is less suited to predicting more central tendencies or lower bounds of the distribution (fig. 10A).
The 90th quantile of dung distribution also has a significant positive relation with estimated forage production (based on soil survey data; fig. $10 B ; p=0.029)$ and negative relation with plot ruggedness index (DEM-derived ruggedness index; fig. $10 C ; p=0.023$ ). The model fit was improved by conducting a multiple-90th-quantile regression that includes all three independent variables (log cost-distance, potential forage production, plot ruggedness, and an interaction of plot potential forage production and ruggedness; table 10, fig. 10D). Such multiple predictor models have been used in other cattle distribution studies (Senft and others, 1983; Wade and others, 1998; Brock and Owensby, 2000; Ganskopp and Bohnert, 2009). The results presented here suggest a quantile regression approach may be more suited to estimating potential cattle use than a least-squares approach.
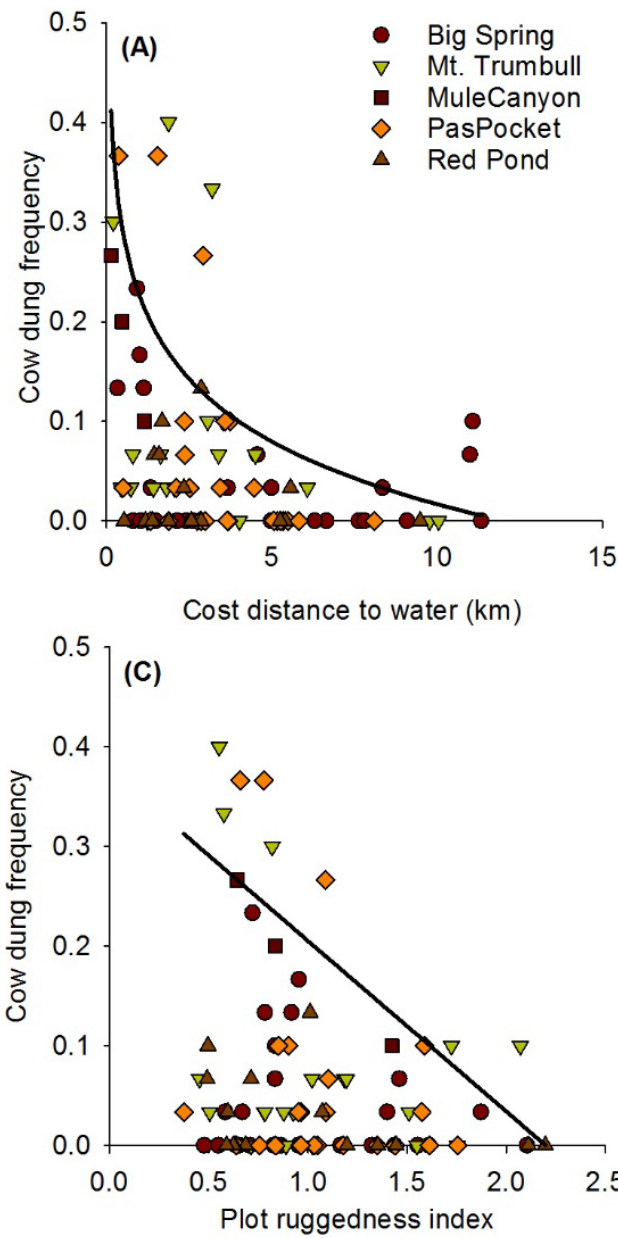

(B)
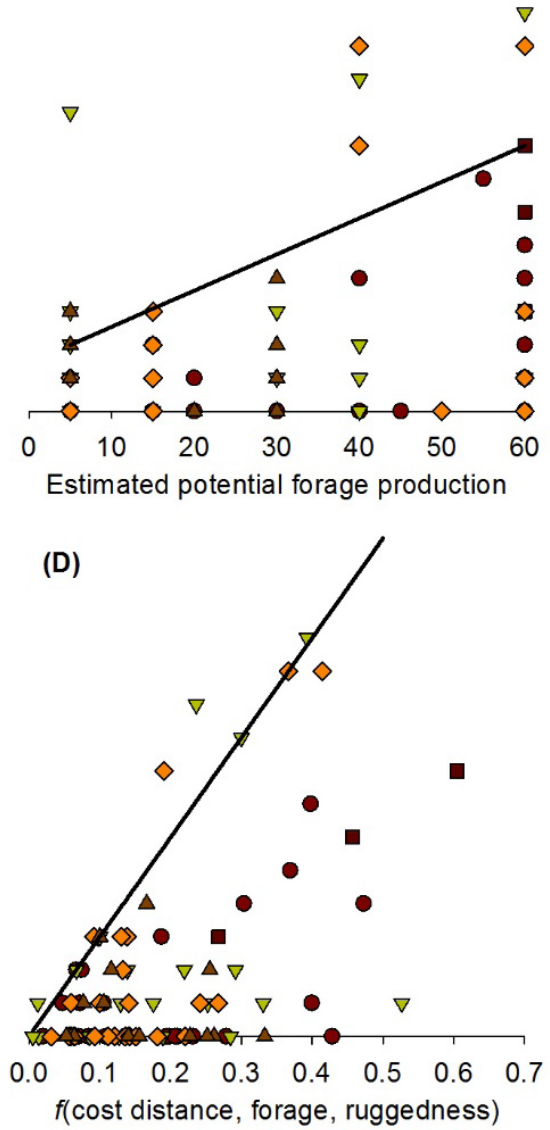

Figure 10. Plots showing the relation between observed cow dung frequency and $(A)$ cost-distance to water, $(B)$ predicted forage production based on correlated soil map unit component (in pounds per acre), $(C)$ plot ruggedness index, and $(D)$ a multiple regression of all three explanatory variables. Data for each allotment are shown. Black line depicts a 90-percent quantile regression fit. km, kilometers. 


\section{Low Desert}

\section{Landscape Setting, Soils, and Rangeland Indicators}

Ecological site groups in the low desert are primarily distinguished by soil parent material, soil depth, soil horizons, slope, and landscape position (table 6, fig. 11). The four plots established in the gypsum hill area of the Tassi allotment were all classified to the same ESD and were placed in one ESG (gypsum). The other two groups (shallow limestone and deep mixed) are distinguished primarily by soil depth, soil horizon development, rock fragments, and landscape setting (slope and topographic wetness index [TWI]; fig. 11). The shallow limestone group is generally sloping with shallow soils and includes ESDs with these as the primary descriptor. The deep mixed group includes a variety of ESDs because of the range of soils included, however most plots in this group had little soil horizon development (entisols). Very little cattle dung was observed in this allotment (fig. 11G), however, plots in the shallow-slope and low-rock-content deep mixed group had the highest occurrence. This is expected since this allotment was officially closed to grazing at the time of this study and only trespassing cattle were present.

These differences in soils and topography among groups created few significant differences in indicators of site stability, hydrologic function, and plant functional groups (fig. 12). The deep mixed group has the highest bare ground and lowest soil aggregate stability, likely caused by low biological soil crust and rock cover (fig. 12A). The gypsum group has significantly higher biological soil crust cover (cyanobacteria, lichens, and mosses). Examination of plant functional group cover shows that the deep mixed group has a high cover of perennials, driven by high woody cover (fig. 12B). Looking at individual species, Ambrosia dumosa and Larrea tridentata occur across all groups with some among-group trends evident but no significant differences detected. The deep mixed sites had a high frequency of the invasive annual grass Schismus arabicus (fig. 12C).

Indicators of site stability and hydrologic function in the low desert show strongest correlation with measures of plot topographic setting and plot rockiness (fig. 13). Run-in areas (high TWI, high flow accumulation, and shallow slope) have high bare ground and low ground cover, potentially because of less protective rock cover. There is also a trend of high bare ground and low ground cover on warm aspects (high solar insolation). Soil aggregate stability followed similar trends. Total biological soil crust cover and cover of lichens was positively correlated with amount of exposed bedrock but negatively correlated with surface rockiness. Only proportion of large canopy gaps and soil aggregate stability showed correlation with soil texture variables, with more large gaps but also greater soil stability on fine-textured soils characterized by high water retention at field capacity. Though there is no cattle use currently permitted in the low desert (Tassi allotment), there is still a significant correlation with distance to water, which suggests areas more accessible to water sources have higher bare ground and lower ground cover than more distant parts of the Tassi allotment. This could be caused by historic cattle use, feral cattle and wild burro use (animals were present when field data was collected), or both.

Indicators of biotic integrity in the low desert show high correlation with soil texture and soil depth (fig. 13). Areas with high curvature (run-off location, hill tops, and shoulders) have low cover of woody vegetation, low cover of all perennial species, and low plant diversity. Areas with less exposed bedrock and deep soils tended to have more total cover, and areas with less exposed bedrock, few rocks in the soil profile, and deep soils tended to have high woody and shrub cover. Perennial species in general, and woody species in particular, show a positive correlation with coarse, well-drained surface soil textures. Though cover of perennial grasses and forbs is generally not very high in the low desert, there is significantly high cover of these functional groups in the shallow soil sites.

There is surprisingly little correlation among the two dominant shrubs of the low desert (Ambrosia dumosa and Larrea tridentata) and the suite of edaphic variables (fig. 13). There are no significant relations detected for A. dumosa. $L$. tridentata tends to occur on soils with high gravel cover and soil types that demonstrate some weak level of development (not entisols). Frequency of the two invasive annual species of concern show more correlation with soil and landscape variables. Bromus rubens is correlated with high elevations and deep soils. Schismus arabicus occurs at low elevations and is more common in areas that receive run-in moisture (high TWI) and have coarse surface textures. There is also a significant negative correlation between $S$. arabicus and distance to water sources, suggesting areas that historically have had high cattle use have high frequency of S. arabicus.

\section{Ordinations}

Only two floristic groups were identified for the low desert in the cluster analysis: the Mojave shrub and the Mojave gypsum (table 11). The final NMS has three axes, stress of 9.61, and instability of 0.00000 . Cover in the Mojave shrub group is a mix of annual and woody species, characterized by Ambrosia dumosa and Schismus arabicus. Annual grasses compose the bulk of the graminoid cover in this group. Average richness is moderate (10.6), as is Simpson's diversity $(0.78)$. The Mojave gypsum group is identifiable by its very well developed biological soil crust and sparse vegetation. It supports few species (average richness $=7.7$, Simpson's diversity $=0.76$ ) and low foliar cover (average total foliar cover $=0.13$ ), but Lycium andersonii and Mentzelia affinis are indicators. Sparse vegetation leads to low indicator values and low average richness since no species occur regularly. 
Table 10. Parameter estimates from multiple quantile regression estimating the 90-percent quantile of cattle dung frequency in active grazing allotments.

[Each estimate has 1 degree of freedom. \%, percent]

\begin{tabular}{|c|c|c|c|c|c|}
\hline \multirow{2}{*}{ Parameter } & \multirow{2}{*}{ Estimate } & \multirow{2}{*}{ Standard error } & \multicolumn{2}{|c|}{ 90-percent quantile } & \multirow{2}{*}{$p$-value } \\
\hline & & & Min. & Max. & \\
\hline Intercept & 0.6699 & 0.1689 & 0.3891 & 0.9507 & $<0.001$ \\
\hline Log cost-distance to water & -0.1969 & -0.2787 & -0.1151 & -4.00 & $<0.001$ \\
\hline Soil survey perennial grass production & 0.0079 & 0.0023 & 0.0040 & 0.0118 & 0.001 \\
\hline Ruggedness & 0.0737 & 0.0755 & -0.0518 & 0.1992 & 0.332 \\
\hline Ruggedness $\times$ perennial grass production & -0.0044 & 0.0020 & -0.0078 & -0.0011 & 0.029 \\
\hline
\end{tabular}
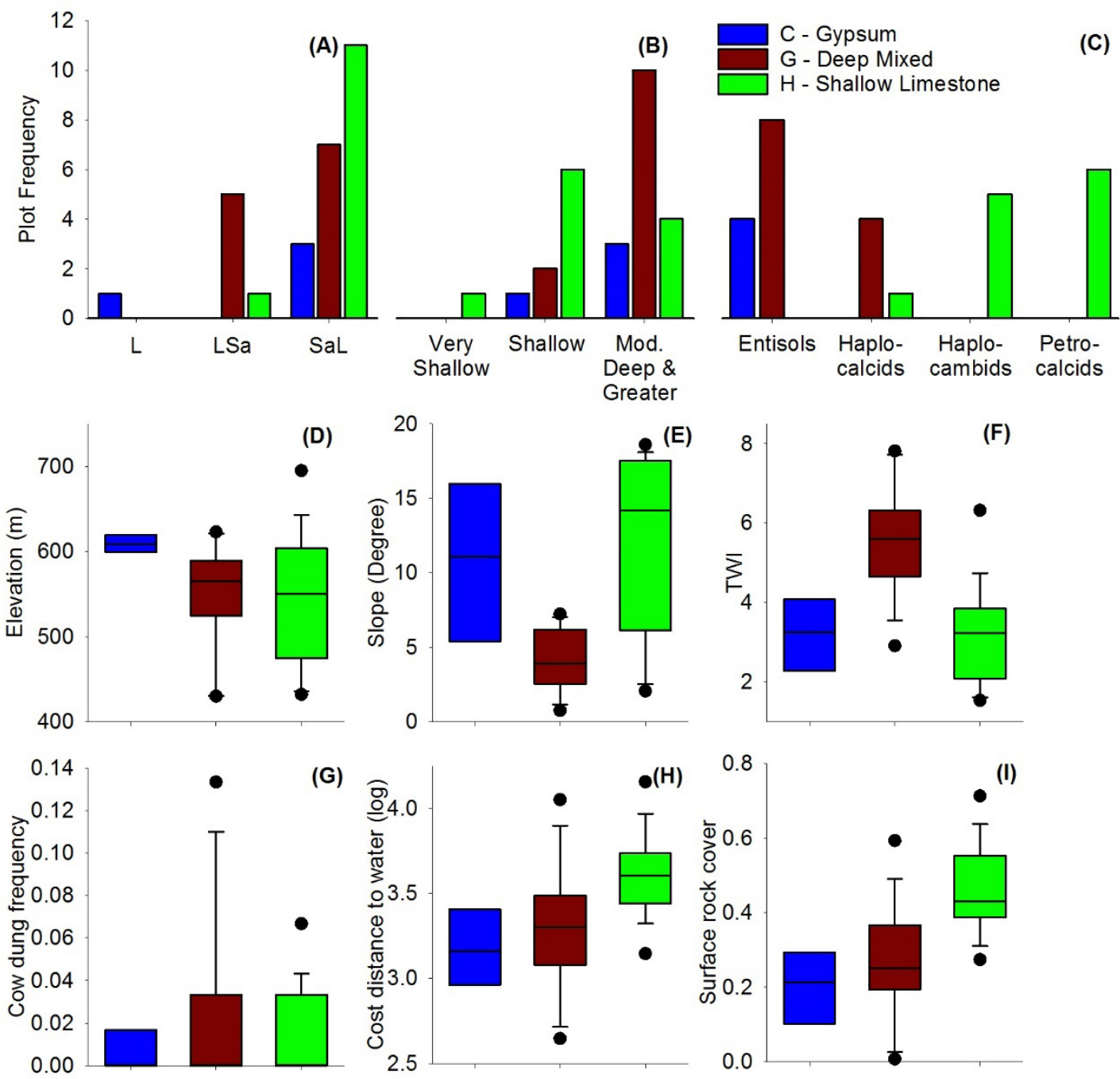

Figure 11. Plots characterizing the low desert ecological site groups. See figure 6 and table 6 for more information. Plots show the frequency of $(A)$ surface soil texture class (L, loam; LSa, loamy sand; SaL, sandy loam), $(B)$ soil depth class, $(C)$ soil taxonomy, $(D)$ elevation (in meters $[\mathrm{m}]),(E)$ slope, $(F)$ topographic wetness index (TWI), $(G)$ observed cow dung, $(H)$ log cost-distance to water, and $(/)$ surface rock cover. Box and whisker plots are shown for continuous variables, denoting 25th, 50th, and 75th quantiles (boxes); 10th and 90th quantiles (whiskers); and outliers (dots). 

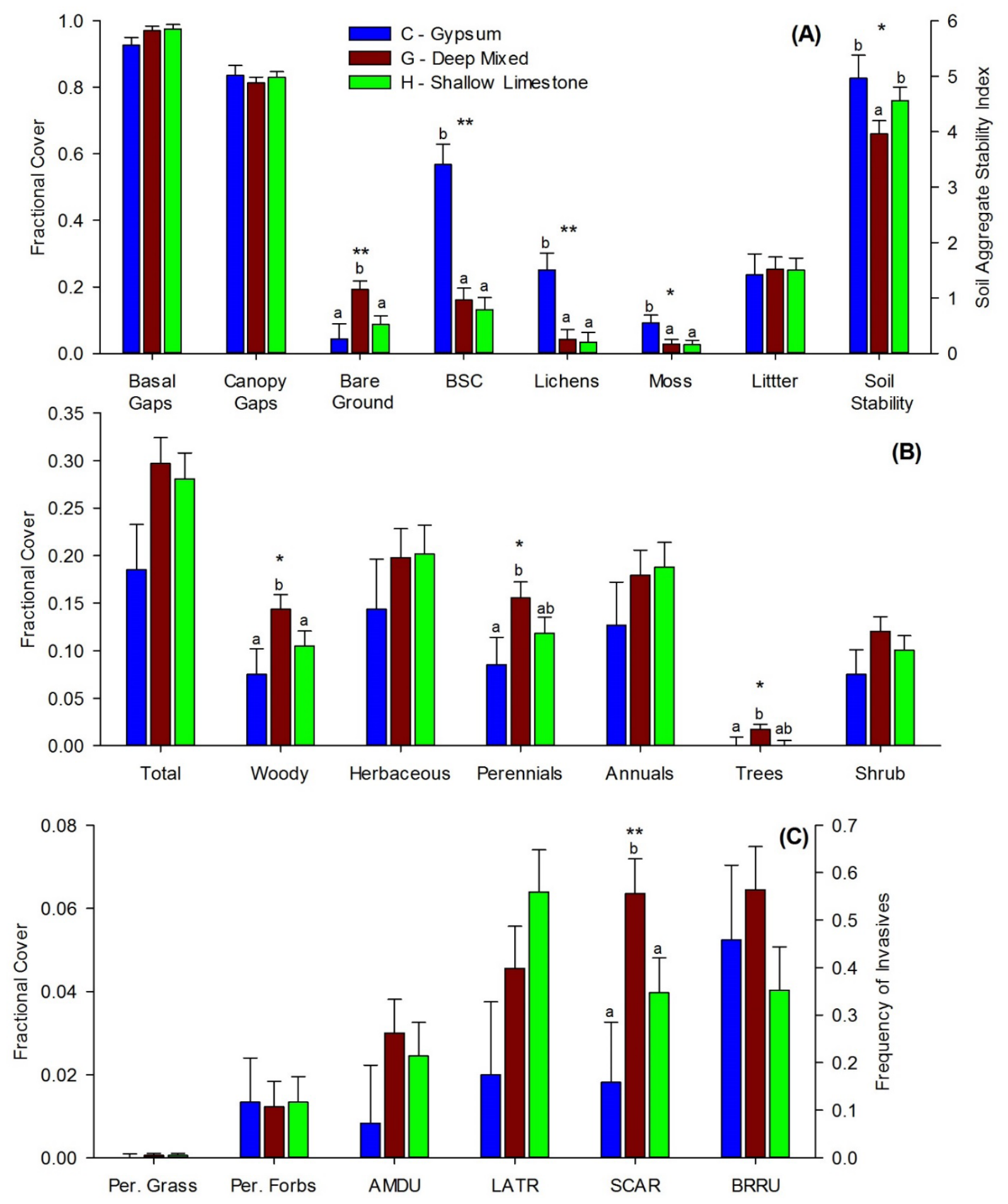

Figure 12. Plots showing fractional cover of the low desert ecological site groups. See figure 6 and table 6 for more information. $A$, Soil and hydrologic function indicators; $B$, plant community functional group cover; and $C$, dominant species cover and invasive species frequency. ${ }^{*}$ indicates $p<0.10 ;{ }^{* *}$ indicates $p<0.05$ for ecological site group differences from mixed model analysis of variance. Where analysis of variance detected differences among ecological site groups, bars with the same letter (a or b) do not differ. BSC, biological soil crust; per., perennial; AMDU, Ambrosia dumosa; LATR, Larrea tridentata; SCAR, Schismus arabicus; BRRU, Bromus rubens. 


\begin{tabular}{|c|c|c|c|c|c|c|c|c|c|c|c|c|c|c|c|c|c|c|c|c|c|}
\hline \multirow[b]{3}{*}{ Indicators } & \multicolumn{6}{|c|}{ Landscape setting } & \multicolumn{10}{|c|}{$\begin{array}{ll}\text { Soil surface properties } \\
\end{array}$} & \multicolumn{2}{|c|}{ Cattle } & \multicolumn{3}{|c|}{ Soil Classes } \\
\hline & \multirow[b]{2}{*}{ Elev. } & \multicolumn{3}{|c|}{ Flow } & \multirow{2}{*}{$\begin{array}{l}\text { Curv- } \\
\text { ature }\end{array}$} & \multirow{3}{*}{$\begin{array}{l}\text { Solar } \\
\text { Insol. }\end{array}$} & \multirow{2}{*}{$\begin{array}{l}\text { Bed- } \\
\text { rock }\end{array}$} & \multirow{2}{*}{$\begin{array}{l}\text { Cob- } \\
\text { ble }\end{array}$} & \multirow{2}{*}{$\begin{array}{l}\text { Gra- } \\
\text { vel }\end{array}$} & \multirow{2}{*}{$\begin{array}{l}\text { All } \\
\text { Rock }\end{array}$} & \multirow{2}{*}{$\begin{array}{l}\text { A-Hor. } \\
\text { Frag. }\end{array}$} & \multirow[b]{2}{*}{ Sand } & \multirow{3}{*}{ Clay } & \multirow{3}{*}{$\begin{array}{l}\text { Sat. } \\
\text { Con }\end{array}$} & \multirow{3}{*}{ AWC } & \multirow{3}{*}{$\begin{array}{l}\text { Field } \\
\text { Cap }\end{array}$} & \multirow{3}{*}{$\begin{array}{l}\text { Cow } \\
\text { Dung }\end{array}$} & \multirow{2}{*}{$\begin{array}{l}\text { Dist. } \\
\text { Water }\end{array}$} & \multirow{3}{*}{\multicolumn{3}{|c|}{$\begin{array}{l}\text { Dep- Tex- Soil } \\
\text { th ture Tax. }\end{array}$}} \\
\hline & & TWI & Acc. & Slope & & & & & & & & & & & & & & & & & \\
\hline & & & & & & & Soil an & nd site s & stability & and hy & rdologic & function & & & & & & & & & \\
\hline Basal Gaps & -0.15 & 0.29 & 0.29 & -0.26 & -0.42 & 0.13 & -0.67 & 0.11 & 0.31 & 0.27 & -0.24 & 0.01 & -0.01 & 0.05 & -0.02 & -0.01 & 0.02 & 0.03 & 0.78 & 0.80 & 0.60 \\
\hline Canop & 15 & 0.02 & -0.04 & 0.09 & 0.03 & 0.15 & -0.01 & 0.04 & 0.01 & 0.06 & 0.05 & -0.47 & 0.48 & -0.41 & 0.45 & & -0.46 & 0.01 & 0.09 & 0.03 & 0.51 \\
\hline Bare Ground & 16 & 0.61 & 0.49 & .50 & -0.28 & 0.38 & -0.01 & -0.39 & -0.45 & -0.45 & -0.31 & 0.35 & -0.31 & 0.34 & -0.37 & -0.34 & 0.15 & -0.48 & 0.73 & 0.26 & 0.15 \\
\hline Groun & & -0.53 & & & 0.19 & & & 0.43 & 0.48 & 0.50 & 0.20 & -0 & 0.24 & & 0.27 & 26 & -0.06 & 0.54 & 0.64 & & 0.24 \\
\hline BSC & & & & & & & & & & & & & & & & & .10 & & & & 33 \\
\hline Li & & & & & & & & & & & & & & & & & 17 & & & & \\
\hline M & & & & & & & & & & & & & & & & & & & & & \\
\hline & & -0.07 & & & 0.02 & & & & & -0.26 & & -0.03 & -0.02 & & & & 0.08 & -0.12 & 0.51 & & 0.81 \\
\hline & & -0.53 & & & 0.34 & & & 0. & & 0.03 & & -0.38 & & & & & -0.14 & & & & 0.16 \\
\hline & & & & & & & & & & & & & & & & & & & & & \\
\hline & & 0.40 & & -0.18 & -0.52 & & -0.36 & 0. & 29 & 0.25 & & 0.21 & & & & & 0.24 & -0.13 & & & 0.03 \\
\hline & & 0.21 & & -0.05 & -0.25 & & -0.50 & -0.17 & & -0.14 & & & & & -0.23 & -0 & 0.44 & 0.02 & & & 0.59 \\
\hline & & 26 & & .21 & -0.39 & & & & & & & & & 51 & $1-0$ & & .43 & -0.04 & & & 0.23 \\
\hline & & 10 & & & -0.10 & & -0 & -0.30 & -0.27 & -0.27 & & 0.04 & -0.09 & -0.05 & 0.00 & & 0.28 & -0.05 & & & 0.68 \\
\hline Perennia & -0.03 & 0.24 & 0.28 & -0.17 & -0.42 & -0.02 & -0.49 & 0.18 & 0.16 & 0.11 & & 0.47 & -0.46 & 0.49 & -0.47 & -0.47 & 0.50 & 0.04 & .05 & & 0.37 \\
\hline Annual & & 0.10 & 07 & 0.03 & -0.06 & -0. & -0.30 & -0.33 & -0.26 & -0.28 & & 03 & -0.08 & -0.07 & 0.01 & -0.04 & 0.25 & -0.06 & 0.13 & & 0.69 \\
\hline Tree & & 0.38 & & .22 & -0.31 & & & & & & & & & 0.52 & & & 0.08 & -0.14 & .30 & & 0.17 \\
\hline Shru & & 0.15 & & -0.13 & -0.31 & 5 & -0.48 & 6 & 0.21 & 0.08 & & & -0 & 36 & -1 & & 0.39 & -0.05 & 0.09 & 0.17 & 0.20 \\
\hline & & 0.02 & & & -0.07 & & -0.07 & -0.24 & -0.06 & -0.02 & & & & & & & 0.12 & -0.08 & & & 0.37 \\
\hline & & -0.03 & & & -0.13 & & -0 . & 0.10 & -0.02 & 0.10 & & & & & & & 0.29 & 0.26 & & & 0.49 \\
\hline & & & & & & & & & & & & & & & & & & & & & \\
\hline & & & & & & & & & & & & & & & & & 0.30 & -0.04 & & & 0.21 \\
\hline & & -0.15 & & & & & & & & & & & & & & & & 0.13 & & & 0.02 \\
\hline & & & & & & & & & & & & & & & & & & -0.16 & & & 0.46 \\
\hline SCAR & & & & & & & & & & -0.32 & & & & & & & & & 0.07 & & 0.62 \\
\hline & & & & & & & & & & & & & & & & & & & & & \\
\hline & .2 & 0.61 & & -0.46 & -0.50 & & -0.58 & -0.02 & 0.10 & -0.01 & -0.4 & & -0 & & -0. & & & -0.32 & & & 0.27 \\
\hline FXX15-2 & 4 & -0.12 & -0.14 & & 0.14 & & 0. & & 0.33 & 0.3 & 0. & -0.04 & 0.11 & 0.04 & & & -0.19 & 0.22 & 0.05 & 0.1 & 0.74 \\
\hline Axis-3 & -0.44 & -0.05 & -0.16 & -0.05 & 0.28 & 0.06 & 0.27 & -0.11 & 0.02 & 0.00 & 0.40 & 0.12 & -0.14 & -0.01 & -0.08 & -0.11 & -0.23 & -0.05 & 0.09 & 0.06 & 0.29 \\
\hline
\end{tabular}

Figure 13. Plot showing correlations between rangeland health indicators, ordination axes (nonmetric multidimensional scaling [NMS]), and landscape setting, soil, and cattle factors for low desert settings. See table 1 for descriptions of rangeland health indicators (left column) and table 5 for descriptions of edaphic factors (top row). Cell values are Pearson correlation coefficients (for continuous variables; bold values indicate $p$-values $<0.05$ ) or $p$-values from ANOVA tests (for soil classes). Cell color shading provides further emphasis on correlation strength (dark green, strong positive; yellow, near zero; and dark red, strong negative) or ANOVA p-value strength (dark green is strong and white is weak).

Table 11. Floristic groups in the low desert climate zone identified by cluster analysis and indicator species analysis.

[In addition to functional indicators, species with statistically significant $(p<0.05)$ indicator values are listed, followed by indicator value in parentheses. SD, standard deviation; $\mathrm{N}$, number]

\begin{tabular}{lccc}
\hline \multicolumn{1}{c}{ Indicator } & Mean (SD) & Min. & Max. \\
\hline Total foliar cover & $0.29(0.09)$ & 0.12 & 0.43 \\
Woody cover & $0.12(0.05)$ & 0.03 & 0.23 \\
Graminoid cover & $0.10(0.08)$ & 0.00 & 0.30 \\
Annual cover & $0.19(0.09)$ & 0.08 & 0.40 \\
Avg. soil stability & $4.22(0.84)$ & 2.83 & 5.67 \\
Ambrosia dumosa (84) & $0.03(0.03)$ & 0.00 & 0.08 \\
Schimus arabicus (82) & $0.03(0.04)$ & 0.00 & 0.13 \\
Bare soil (75) & $0.14(0.11)$ & 0.01 & 0.39 \\
\hline
\end{tabular}

\begin{tabular}{lccc}
\hline \multicolumn{1}{c}{ Indicator } & Mean (SD) & Min. & Max. \\
\hline & Mojave gypsum (N = 3) & & \\
\hline Total foliar cover & $0.13(0.09)$ & 0.07 & 0.24 \\
Woody cover & $0.06(0.05)$ & 0.00 & 0.11 \\
Graminoid cover & $0.04(0.07)$ & 0.00 & 0.12 \\
Annual cover & $0.08(0.07)$ & 0.03 & 0.15 \\
Avg. soil stability & $5.49(0.36)$ & 5.07 & 5.72 \\
Biological soil crust (82) & $0.69(0.09)$ & 0.59 & 0.76 \\
Lycium andersonii (67) & $0.01(0.01)$ & 0.00 & 0.02 \\
Mentzelia affinis (67) & $0.00(0.00)$ & 0.00 & 0.01 \\
\hline
\end{tabular}


There is evidence for the importance of landscape and soil setting as controlling factors for indicators of plant community composition. There is strong agreement between Mojave gypsum floristic group and the gypsum ESG, whereas the Mojave shrub group was evenly split between the deep mixed and shallow limestone ESGs (table 8). Examination of relations among diversity, NMS axes, and edaphic gradients suggests local topographic setting (TWI, flow accumulation, slope, and curvature) plays an important role in controlling the primary axis of community composition (axis-1; fig. 13). Proportion of exposed bedrock, A-horizon rockiness, properties associated with soil texture, and soil depth are all also significantly correlated with the primary axis. The other two axes identified in the NMS (axis-2 and axis-3), show less correlation with measured landscape and soil factors, with significant correlations only observed for elevation (for both axes) and sand percentage (for axis-3).

\section{Middle Desert}

\section{Landscape Setting, Soils, and Rangeland Indicators}

The four ESGs of the middle desert are distinguished primarily by parent material (basalt, sandstone, and limestone), soil depth (shallow to deep), and slope (table 6, fig. 14). There are two ESGs that are characterized by shallow soils but have contrasting soil diagnostic horizons (and taxonomy; fig. 14C). Shallow limestone plots are all torriorthents, which are soils that have very little soil development, whereas shallow mixed plots generally are in taxonomic classes that require calcic horizon development. The other two ESGs are moderately deep to deep and generally not steeply sloping but have contrasting parent materials and resulting texture and mineralogy.

Deep basalt plots are generally finer in texture than deep limestone plots, though deep limestone plots tend to be more hydrologically enhanced (high TWI; fig. 14F). Cattle dung frequency is highest in the deep limestone plots (fig. 14G).

Groups in the middle desert exhibit large and consistent differences in ecosystem indicators of site stability and hydrologic function (fig. 15A) and plant functional and species occurrence (fig. 15B, C). The deep limestone group has lower cover of large basal $(>200 \mathrm{~cm})$ and canopy $(>100$ $\mathrm{cm})$ gaps than other ESGs. The shallow sandstone group has the highest biological soil crust cover and the deep basalt and deep limestone groups have the lowest. Soil aggregate stability is highest in the shallow mixed and deep limestone groups, shallow sandstone groups have an intermediate level of aggregation, and the deep basalt group has the lowest aggregate stability. ESG plant functional group and species cover indicate differences in basal and canopy gaps are driven by very high perennial grass cover in the deep limestone group. The shallow mixed group has significantly higher cover of Coleogyne ramosissima, leading to an overall higher cover of shrubs, than the other ESGs, whereas the shallow sandstone group has intermediate cover. Gutierrezia spp. cover is also high in the deep limestone group. Bromus rubens frequency shows some specificity to ESGs, with the deep limestone group having the lowest and deep basalt and shallow mixed both showing similarly common occurrence. Frequency of the invasive species Erodium cicutarium was highest in the deep limestone group and lowest in the deep basalt group.

In the middle desert, site stability and hydrologic function indicators associated with soil cover (bare ground, ground cover, and biological soil crusts) show the most correlation with landscape and soil setting variables (fig. 16). Sites with high TWI, shallow slopes, and low rock cover tend to have more bare ground and less ground cover. Total cover of biological soil crusts as well as cover of lichens and mosses are significantly positively correlated with proportion of exposed bedrock, negatively correlated with most rock cover indicators, and positively correlated with coarse soil textures. Together, these suggest that biological soil crusts are most prevalent on shallow, sandy soil settings. Soil stability and biological soil crust cover both showed decreasing trends with elevation. Moss cover and soil stability are negatively correlated with solar insolation, indicating they are high in the cool aspects. Correlations with cow dung frequency, distance to water, and the cattle index suggest areas with high cattle activity have high bare ground and low ground cover.

There are fewer associations among biotic integrity indicators, landscape, and soil setting variables in the middle desert than in indicators of soil and site stability and hydrologic function (fig. 16). There is less total cover in sites with high amounts of exposed bedrock and less cover of herbaceous and annual functional types on coarse well-drained soils. Similarly, few correlations were detected between functional group cover and the three measures of cattle use. There is some evidence of high shrub cover where cattle use is low (cow dung correlation) and high tree and annual cover where cattle use is low, but the lack of consistent trends among other functional group indicators suggests these correlations may be spurious.

Cover of dominant species and species of concern demonstrate more correlation with landscape and soil factors than functional group cover in the middle desert (fig. 16). Ephedra spp. cover is positively correlated and Larrea tridentata cover is negatively correlated with elevation. Ephedra cover is also positively correlated with steep slope and negatively correlated with run-in positions (TWI). Ephedra is the only dominant species that shows any correlation with soil properties, preferring soils with high rock cover but that are not excessively drained (negative correlation with soil conductivity). Bromus rubens frequency is also positively correlated with soil rockiness (rock cover as well as A-horizon rock content) and soil textures that afford high water retention (high clay, low conductivity, and high 


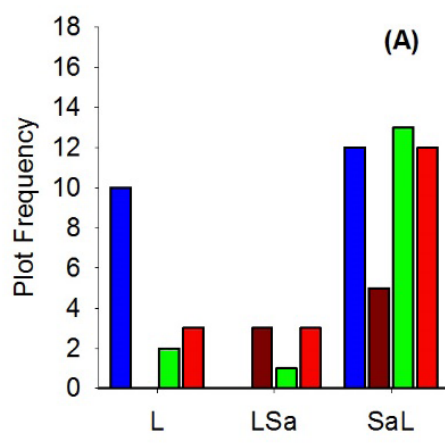

(B)
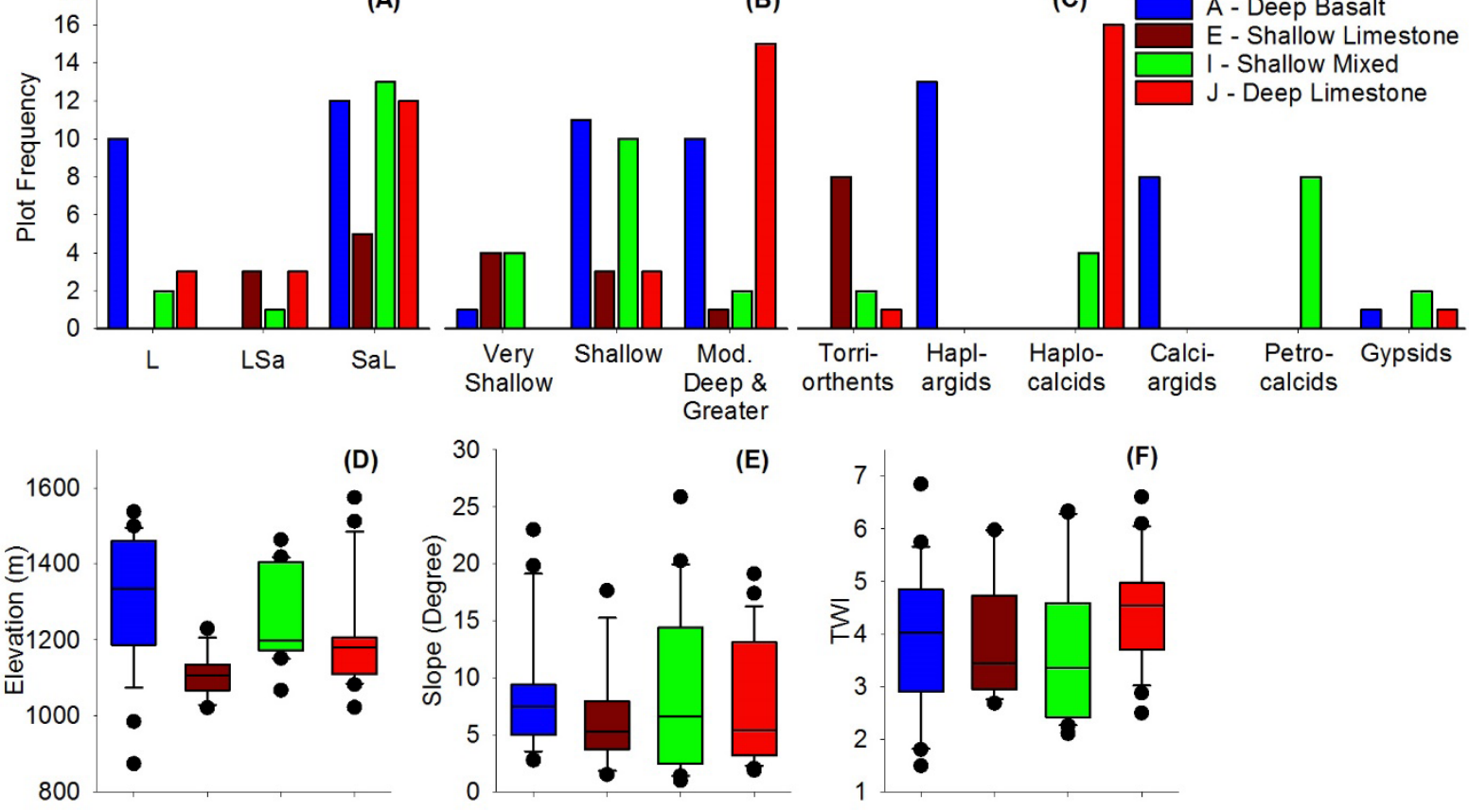

(E)
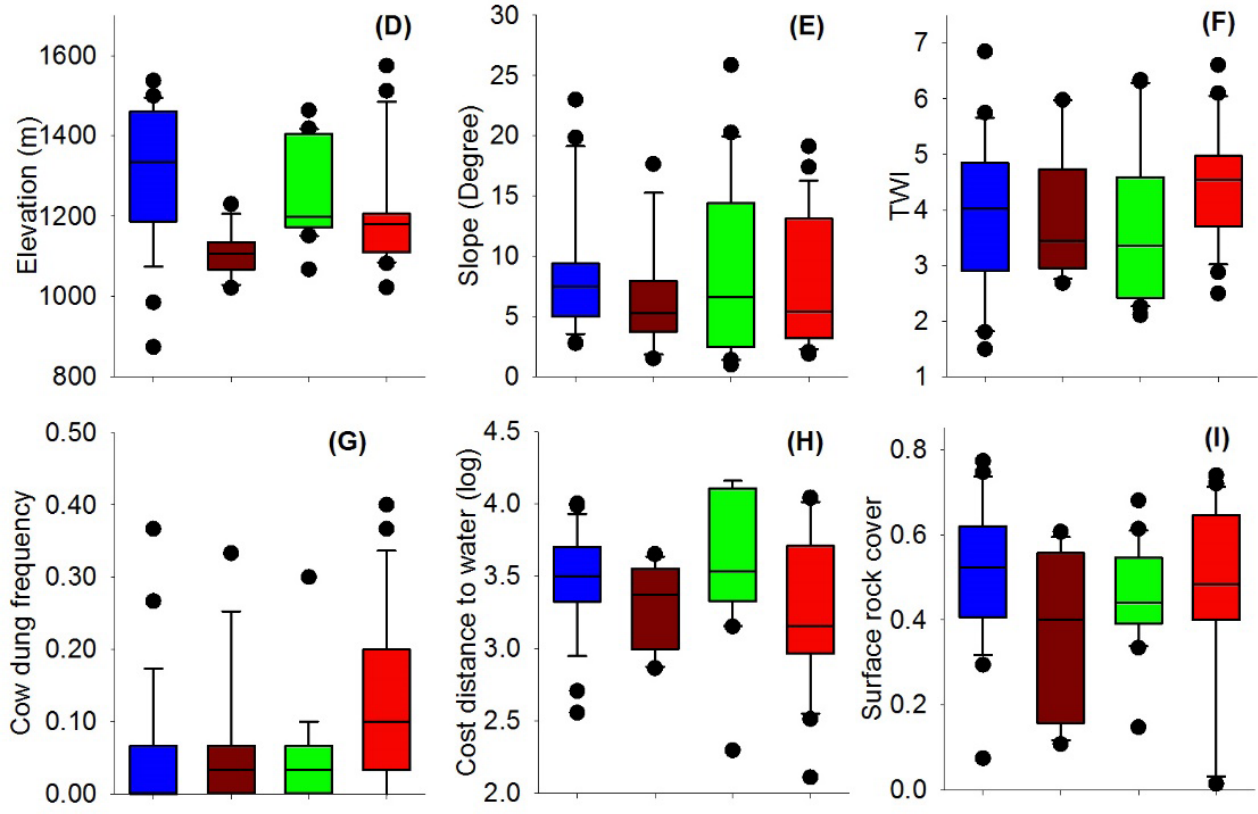

Figure 14. Plots characterizing the middle desert ecological site groups. See figure 6 and table 6 for more information. Plots show the frequency of $(A)$ surface soil texture class (L, loam; LSa, loamy sand; SaL, sandy loam), $(B)$ soil depth class, $(C)$ soil taxonomy, $(D)$ elevation (in meters $[\mathrm{m}]),(E)$ slope, $(F)$ topographic wetness index (TWI), $(G)$ observed cow dung, $(H)$ log cost-distance to water, and (/) surface rock cover. Box and whisker plots are shown for continuous variables, denoting 25th, 50th, and 75th quantiles (boxes); 10th and 90th quantiles (whiskers); and outliers (dots). 

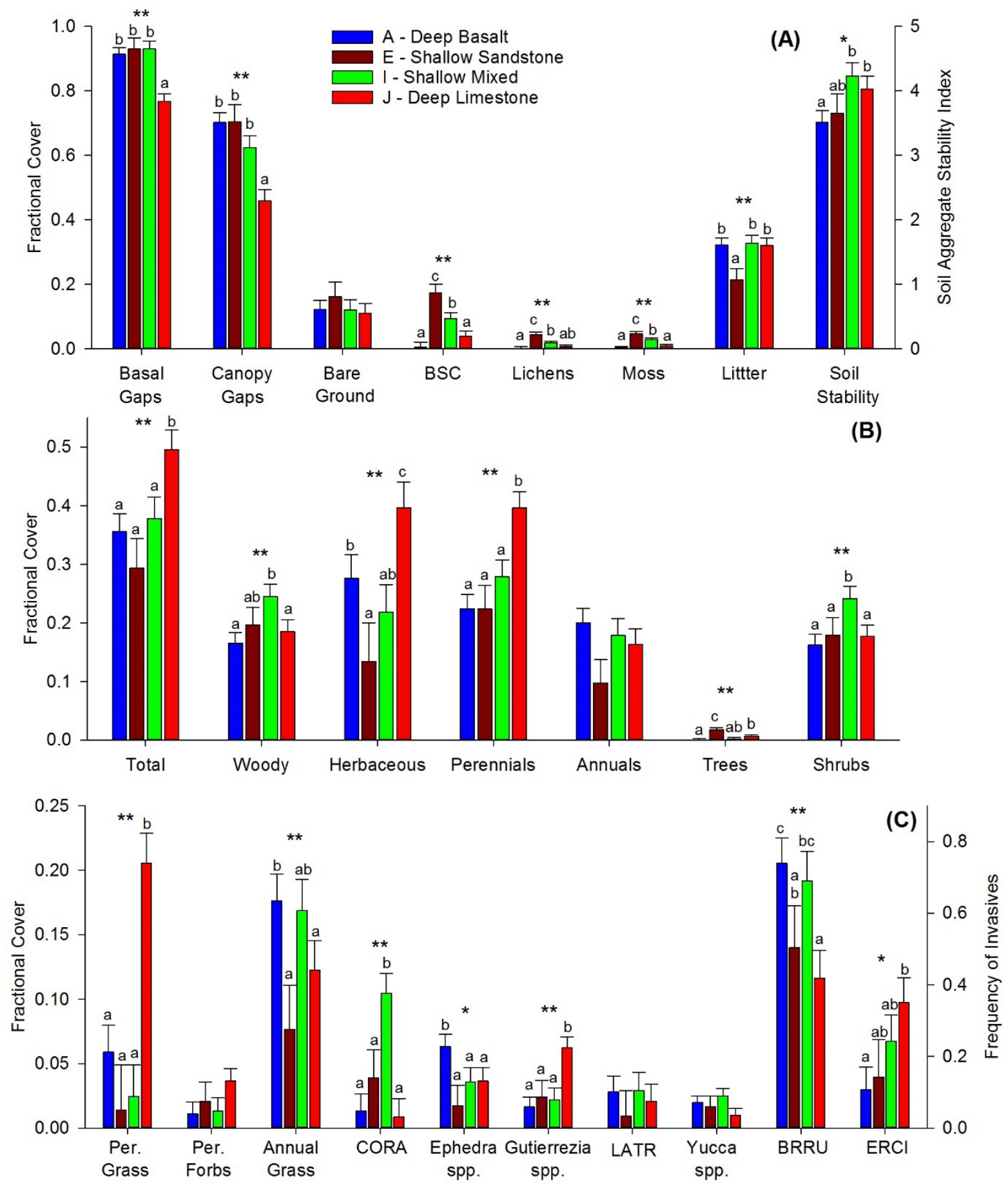

Figure 15. Plots showing fractional cover of the middle desert ecological site groups. See figure 6 and table 6 for more information. $A$, soil and hydrologic function indicators; $B$, plant community functional group cover; and $C$, dominant species cover and invasive species frequency. ${ }^{*}$ indicates $p<0.10$; ${ }^{* *}$ indicates $p<0.05$ for ecological site group differences from mixed model analysis of variance. Where analysis of variance detected differences among ecological site groups, bars with the same letter (a, b, or c) do not differ. BSC, biological soil crust; per., perennial; CORA, Coleogyne ramosissima; LATR, Larrea tridentata, BRRU, Bromus rubens, ERCI, Eragrostis cilianensis. 


\begin{tabular}{|c|c|c|c|c|c|c|c|c|c|c|c|c|c|c|c|c|c|c|c|c|c|c|}
\hline \multirow[b]{2}{*}{ dicators } & \multicolumn{6}{|c|}{ Landscape setting } & \multicolumn{10}{|c|}{ Soil surface properties } & \multicolumn{3}{|c|}{ Cattle } & \multicolumn{3}{|c|}{ Soil Classes } \\
\hline & lev. & TWI & $\begin{array}{l}\text { Flow } \\
\text { Acc. }\end{array}$ & $\begin{array}{l}\text { Slop } \\
\text { e }\end{array}$ & $\begin{array}{l}\text { Curv- } \\
\text { ature }\end{array}$ & $\begin{array}{l}\text { Solar } \\
\text { Insol. }\end{array}$ & $\begin{array}{l}\text { Bed- } \\
\text { rock }\end{array}$ & $\begin{array}{l}\text { Cob- } \\
\text { ble }\end{array}$ & $\begin{array}{l}\text { Gra- } \\
\text { vel }\end{array}$ & $\begin{array}{l}\text { All } \\
\text { Rock }\end{array}$ & $\begin{array}{l}\text { A-Hor. } \\
\text { Frag. }\end{array}$ & Sand & Clay & $\begin{array}{l}\text { Sat. } \\
\text { Con }\end{array}$ & AWC & $\begin{array}{l}\text { Field } \\
\text { Cap }\end{array}$ & $\begin{array}{l}\text { Cow } \\
\text { Dung }\end{array}$ & $\begin{array}{l}\text { Dist. } \\
\text { Water }\end{array}$ & $\begin{array}{l}\text { Cattle } \\
\text { Index }\end{array}$ & $\begin{array}{l}\text { Dep- } \\
\text { th }\end{array}$ & $\begin{array}{l}\text { Tex- } \\
\text { ture }\end{array}$ & $\begin{array}{l}\text { Soil } \\
\text { Tax. }\end{array}$ \\
\hline \multicolumn{23}{|c|}{ Soil and site stability and hyrdologic function } \\
\hline asal Gaps & -0.21 & -0.02 & -0.10 & 0.00 & 0.02 & -0.13 & .20 & -0.09 & -0.22 & -0.12 & -0.17 & 0.03 & -0.04 & 0.04 & & -0.03 & -0.07 & 0.15 & -0.30 & 0.11 & 0.93 & 30.00 \\
\hline anopy Gaps & .23 & 0.02 & -0.04 & -0.02 & 0.15 & -0.03 & 0.24 & -0.14 & -0.29 & -0.18 & -0.25 & -0.03 & 0.01 & 0.04 & $4 \quad 0.03$ & 0.02 & 08 & 0.07 & -0.22 & 0.29 & 37 & 70.00 \\
\hline 3are G & 0.12 & 0.23 & 0.04 & -0.34 & -0.17 & 0.16 & 0.13 & -0.33 & -0.54 & -0.68 & -0.39 & 0.04 & -0.08 & 0.17 & -0.03 & -0.06 & 0.50 & -0.28 & 0.30 & 0.83 & .02 & 20.75 \\
\hline Groun & 0.19 & -0.30 & -0.08 & 0.44 & 0.20 & -0.18 & 0.25 & 0.43 & 0.52 & 0.79 & 0.41 & 17 & -0.06 & -0.01 & -0.19 & -0.13 & -0.64 & 0.40 & -0.49 & 0.23 & .01 & 10.16 \\
\hline SSC & & 0.15 & -0.04 & -0.18 & -0.09 & -0.13 & 0.40 & -0.40 & & -0.36 & & 34 & & 0.42 & & & 0.12 & -0.01 & 0.17 & .06 & .00 & 0.00 \\
\hline nens & & 0.22 & 0.00 & -0.27 & .08 & & .40 & & & -0.24 & & 18 & & 0.19 & & & 15 & 04 & & 16 & 32 & 20.08 \\
\hline & & -0.14 & -0.24 & & -0.07 & & .37 & & & -0.16 & & 31 & & 0.31 & & & 23 & 12 & & .01 & 04 & 40.00 \\
\hline & & 0.14 & 0.29 & & & & & 0.04 & 0.23 & 0.01 & & -0.28 & 0.36 & -0.35 & 0.25 & 0.32 & & 34 & & .05 & the & 20.10 \\
\hline & & -0.13 & -0.10 & & & & .05 & 0.19 & -0.04 & 0.07 & & 0.12 & & & & & & & & & & 10.19 \\
\hline \multicolumn{23}{|c|}{ Plant diversity and functional groups } \\
\hline & & & & & & & & 0.08 & & 0.01 & & -0.05 & & & & & & & & .64 & & $\begin{array}{ll}40.10 \\
\end{array}$ \\
\hline & & 0.05 & & & & & & & & & & & & & & & & & & 12 & & 20.14 \\
\hline & & -0.08 & -0 & & & & & & & & & & & 0 & & & & & & 39 & & 20.06 \\
\hline & & 0.09 & & & & & & & & & & & & -0.25 & & & & & & & .14 & 40.11 \\
\hline & & -0.06 & & 0. & & & & 0 & & & & -0.05 & -0.02 & -0.04 & & & & & & 25 & 0.80 & 0.02 \\
\hline & & 0.20 & & & & & & -0.02 & & & & -0.34 & 0 & -0.35 & & & & & & 38 & , & 20.28 \\
\hline & & 0.07 & & & & & & -0.04 & & -0.07 & & & & & & & & & & & & 60.10 \\
\hline & & .08 & & & & & & & & & & & & & & & & & & & & 80.07 \\
\hline & & & & & & & & & & & & & & & & & & & & & 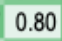 & 0.01 \\
\hline & & $-c$ & -0.1 & & & & & 0 & -0.19 & -0.14 & -0 & & 05 & -0 & & & & & & & 0.23 & 30.05 \\
\hline & & ( & 0.24 & & & & & 0.06 & 0.21 & 0.14 & 0.34 & -0.23 & 0.24 & & & & & & & & & 0.27 \\
\hline \multicolumn{23}{|c|}{ Dominant species and species of concern } \\
\hline & & 00 & & & & & & & & -0.08 & & & 0.00 & & & & & & & & & 0.2 \\
\hline & & -0.26 & -0 & & & & & & & & & & & -0 & & & & & & & i & 0.07 \\
\hline & .08 & & & & & & & & -0.02 & -0.0 & & & 0.02 & -0.02 & -0.04 & & & & & & 0.93 & 30.06 \\
\hline & & & & & & & & & & & & & & & & & & & & & & 60.43 \\
\hline & & & & & & & & -0.22 & & & & & & -0 & & & & & & & 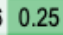 & 50.54 \\
\hline & & & & & & & & & & & & & & & & & & & & & .00 & 0.30 \\
\hline & & & & & & & & & & -0.14 & -0.09 & & & & & & & & & & & \\
\hline \multicolumn{23}{|c|}{ NMS Axis Scores } \\
\hline & & & & & & & I.JI & & & & & -0.33 & .31 & -0.34 & & 0.33 & & & & & & 0.05 \\
\hline & & & & & & & & & & & & & & & & & & & & & & 0.16 \\
\hline & 0.15 & -0.28 & -0.13 & 0.30 & & -0.12 & 0.27 & 0.24 & & 0.19 & -0.14 & 0.08 & -0.10 & 0.15 & -0.08 & -0.09 & 0.06 & -0.14 & 0.12 & 0.09 & & 40.40 \\
\hline
\end{tabular}

Figure 16. Plot showing correlations among rangeland health indicators, ordination axes (nonmetric multidimensional scaling [NMS]), and landscape setting, soil, and cattle factors for middle desert settings. See table 1 for descriptions of rangeland health indicators (left column) and table 5 for descriptions of edaphic factors (top row). Cell values are Pearson correlation coefficients (for continuous variables; bold values indicate $p$-values $<0.05$ ) or $p$-values from ANOVA tests (for soil classes). Cell color shading provides further emphasis on correlation strength (dark green, strong positive; yellow, near zero; and dark red, strong negative) or ANOVA p-value strength (dark green is strong and white is weak).

available water capacity). There are some significant trends in dominant shrub cover relative to cattle variables. Both Coleogyne ramosissima and Ephedra appear to have high cover in locations that receive low cattle pressure. Conversely, Gutierrezia spp. has high cover in locations with high dung frequency, close water sources, and where the cattle index predicts high use. B. rubens frequency is negatively correlated with the cattle index.

\section{Ordinations}

The middle desert contains three floristic groups identified in the cluster analysis: one dominated by grasses (desert grassland), one that is largely characterized by $C$. ramosissima and a mix of shrubs (blackbrush shrubland), and one that is characterized by L. tridentata (creosote slopes; table 12). The final NMS has three axes, stress of 18.03, and instability of 0.00000 .
The desert grasslands have the highest average graminoid cover $(0.30)$ and the highest maximum graminoid cover $(0.73)$ for the study area, whereas woody cover is generally low (0.18; table 12). The species with the highest indicator values are all native perennial grasses, but the composition of those grasses within plots is variable. Simpson's diversity within this group is high (0.81) and average species richness is second highest of the eleven floristic groups (13.2). Many of the species that occur within this group occur in different combinations across the landscape and overlap with either the low desert or the high desert floristic groups. It is a transitional community and has a combination of species that are typically found in the Mojave Desert and on the Colorado Plateau.

Blackbrush shrublands are generally less vegetated than the desert grasslands but are comparable in cover to the creosote slopes (table 12). This group has a mix of woody and graminoid cover, where the woody cover is composed almost entirely of shrubs rather than trees $(0.21$ versus 0.01$)$. 
Table 12. Floristic groups in the middle desert climate zone identified by cluster analysis and indicator species analysis.

[In addition to functional groups, species with statistically significant $(p<0.05)$ indicator values are listed, followed by indicator value in parentheses. SD, standard deviation; $\mathrm{N}$, number]

\begin{tabular}{|c|c|c|c|}
\hline Indicator & Mean (SD) & Min. & Max. \\
\hline \multicolumn{4}{|c|}{ Desert grassland ( $N=32)$} \\
\hline Total foliar cover & $0.46(0.16)$ & 0.07 & 0.88 \\
\hline Woody cover & $0.18(0.09)$ & 0.00 & 0.31 \\
\hline Annual cover & $0.19(0.10)$ & 0.03 & 0.54 \\
\hline Graminoid cover & $0.30(0.14)$ & 0.05 & 0.73 \\
\hline Avg. soil stability & $3.88(0.92)$ & 2.11 & 5.67 \\
\hline Hilaria rigida (67) & $0.05(0.06)$ & 0.00 & 0.24 \\
\hline Muhlenbergia porteri (61) & $0.03(0.03)$ & 0.00 & 0.10 \\
\hline Bouteloua eriopoda (44) & $0.03(0.04)$ & 0.00 & 0.18 \\
\hline $\begin{array}{l}\text { Sporobolus cryptandrus } \\
\text { (39) }\end{array}$ & $0.04(0.09)$ & 0.00 & 0.40 \\
\hline Tridens muticus (25) & $0.01(0.01)$ & 0.00 & 0.03 \\
\hline \multicolumn{4}{|c|}{ Blackbrush shrubland ( $N=26)$} \\
\hline Total foliar cover & $0.32(0.11)$ & 0.15 & 0.62 \\
\hline Woody cover & $0.22(0.10)$ & 0.05 & 0.47 \\
\hline Graminoid cover & $0.14(0.11)$ & 0.00 & 0.38 \\
\hline Annual cover & $0.15(0.11)$ & 0.00 & 0.35 \\
\hline Avg. soil stability & $3.86(0.90)$ & 2.22 & 5.29 \\
\hline $\begin{array}{l}\text { Coleogyne ramosissima } \\
\text { (64) }\end{array}$ & $0.08(0.10)$ & 0.00 & 0.35 \\
\hline Biological soil crust (49) & $0.01(0.04)$ & 0.00 & 0.19 \\
\hline Bare soil (40) & $0.16(0.11)$ & 0.05 & 0.47 \\
\hline Mortonia utahensis (35) & $0.02(0.03)$ & 0.00 & 0.11 \\
\hline \multicolumn{4}{|c|}{ Creosote slopes $(\mathrm{N}=6)$} \\
\hline Total foliar cover & $0.34(0.15)$ & 0.21 & 0.57 \\
\hline Woody cover & $0.19(0.05)$ & 0.11 & 0.27 \\
\hline Graminoid cover & $0.17(0.17)$ & 0.02 & 0.39 \\
\hline Annual cover & $0.20(0.20)$ & 0.02 & 0.49 \\
\hline Avg. soil stability & $3.72(0.65)$ & 2.44 & 4.20 \\
\hline Larrea tridentata (83) & $0.16(0.07)$ & 0.08 & 0.26 \\
\hline Pectis papposa (43) & $0.04(0.06)$ & 0.00 & 0.15 \\
\hline
\end{tabular}

The species with the highest indicator values, although weak, are both native and uncommon in the study area. Mortonia utahensis occurs only in this floristic group, albeit sporadically. Coleogyne ramosissima occurs sporadically across the study range, but more consistently in this floristic group. M. utahensis is typically found in the Mojave Desert, whereas $C$. ramosissima occurs on the Colorado Plateau and into the Mojave. The low indicator values and somewhat low average richness (9.5) are due to the variable composition of the plots. This variability in composition and the mix of species with Mojave Desert and Colorado Plateau affiliations illustrate that this group is also a transitional community. Like the desert grasslands group, this group shares many species with low desert and high desert floristic groups. Soil stability ranges from instable to stable (2.22-5.29), and the average is moderately stable (3.86).

Creosote slopes have moderate levels of average total foliar cover (0.34), of which the woody component is consistent (0.19) and composed of shrubs (table 12). Graminoid and annual covers are variable, but high annual covers correspond with high graminoid covers, indicating the primary driver of graminoid cover is the annual nonnative species Bromus rubens. Since forbs are negligible (0.05), this group is characterized by woody shrubs with little understory or an understory of an annual nonnative grass. Larrea tridentata is the primary shrub in this group, which is reflected in a high indicator value (83). This group has the lowest average richness (6.8) and the lowest diversity (0.52).

Soils and plant community data suggest the middle desert climate zone has a higher diversity in soils and landscapes as well as associated plant communities than any other climate zone (four ESGs and three floristic groups; table 8, fig. 16). Desert grassland floristic groups were evenly split between the deep basalt and shallow limestone ESGs. Blackbrush shrublands occur in all ESGs but are most common in the shallow mixed group, and creosote slopes are most common in the deep basalt group. Correlations between axis scores and environmental variables were strongest with axis-1, which is positively correlated with contributing area (flow accumulation; fig. 16); negatively correlated with amount of exposed bedrock; and positively correlated with A-horizon rockiness, surface soil sand content (and associated soil hydrologic properties), and soil depth. Axis-2 shows no trends with landscape and soil variables and axis- 3 is correlated with sites that have low TWI, steep slopes, and high exposed bedrock.

\section{High Desert and Forest and Savanna}

\section{Landscape Setting, Soils, and Rangeland Indicators}

In the results presented here, we lump the high desert and forest and savanna ESGs, because there is only one ESG identified in the forest and savanna zone and there is high overlap in elevations and associated climates between the two zones (table 6; fig. 17D). The two high desert ESGs are distinguished by both parent material and soil depth. The deep basalt and shallow limestone groups both have shallow to moderate slopes, however, as the names indicate, they have differing parent materials and dominant depths (fig. 17B). The high desert basalt group is also generally deeper and finer textured than the high desert shallow limestone group. The shallow loam group in the forest and savanna has a similar elevation range as the high desert basalt group. The shallow loam group is generally shallower and coarser in texture than 

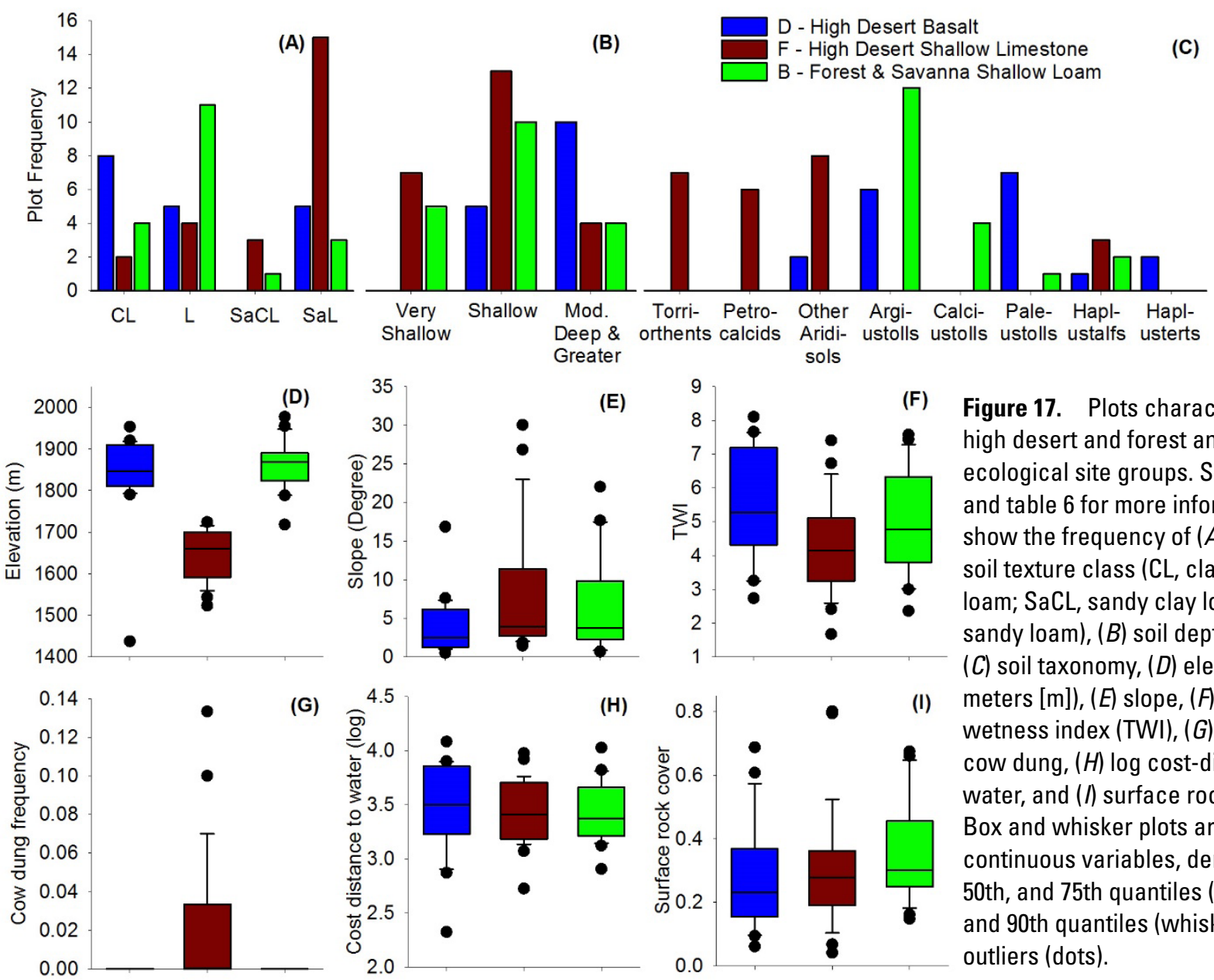

Figure 17. Plots characterizing the high desert and forest and savanna ecological site groups. See figure 6 and table 6 for more information. Plots show the frequency of $(A)$ surface soil texture class (CL, clay loam; $L$, loam; SaCL, sandy clay loam, SaL, sandy loam), (B) soil depth class, $(C)$ soil taxonomy, $(D)$ elevation (in meters $[\mathrm{m}]),(E)$ slope, $(F)$ topographic wetness index (TWI), $(G)$ observed cow dung, $(H)$ log cost-distance to water, and ( $/$ ) surface rock cover. Box and whisker plots are shown for continuous variables, denoting 25th, 50th, and 75th quantiles (boxes); 10th and 90th quantiles (whiskers); and outliers (dots).

the high desert basalt ESG. Cattle use, as indicated by dung frequency, is absent on the high desert basalt group and forest and savanna shallow loam because these ESGs are restricted to the Home Ranch allotment (fig. 6), which has not been grazed by livestock since 2003. Cattle dung was observed in the high desert shallow limestone group, but frequencies were generally low (fig. 17G).

Indicators of soil and site stability, hydrologic function, and plant functional group differed among the three ESGs (fig. 18A, B). There were no differences in cover of large basal gaps, however, canopy gaps were lower in the forest and savanna shallow loam than the high desert shallow limestone ESG. Bare ground was significantly lower in the forest and savanna ESG than the high desert ESGs. Biological soil crust cover was greatest in the shallow limestone group, potentially because of soil differences and low foliar and litter cover. These trends in gaps, bare ground, and litter are explained in part by trends in vascular plant cover. There were significant differences among all ESGs in indicators of biotic integrity. Total, perennial, and woody cover differed, with cover lowest in the shallow limestone group and highest in the shallow loam group. However, cover of annual grasses, Artemsia spp., and Gutierrezia spp. were significantly higher in the shallow limestone group than other groups (fig. 18C). The two high elevation ESGs had similar high cover of trees (primarily juniper with some pinyon). The two species of the invasive Bromus annual grasses (B. rubens and B. tectorum) were significantly more frequent in the shallow limestone ESG.

Across the high desert and forest and savanna ESGs, there are a number of significant correlations between the soil and site stability and hydrologic function indicators and landscape and soil setting properties (fig. 19). The proportion of canopy gaps is high at low elevations and in landscape settings with high curvatures (more convex). Both ground cover and litter increase with elevation. Unexpectedly, the proportion of bare ground increases with degree of hydrologic enhancement (high TWI, high flow accumulation, and shallow slopes) but also increases in warm aspects (high solar insolation). Rocky areas have low bare ground and high ground cover. Litter cover is also reduced in areas with high bedrock exposure and coarse surface soils. There is no association between cost-distance to cattle water sources and indicators of soil and site stability and hydrologic function.

Indicators of biotic integrity show some association with landscape setting variables and many associations with soil properties (fig. 19). High elevations tend to have high total and 

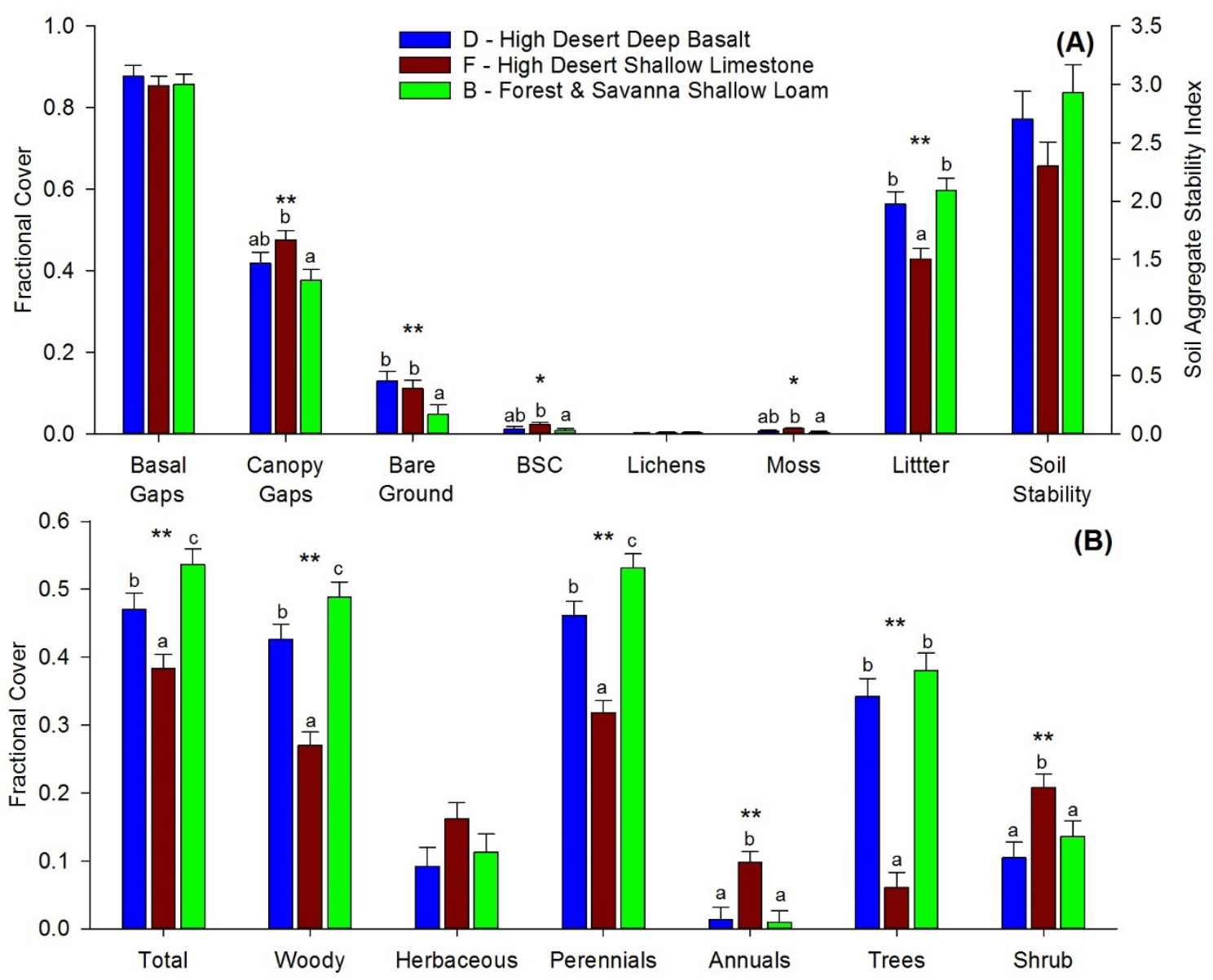

B)

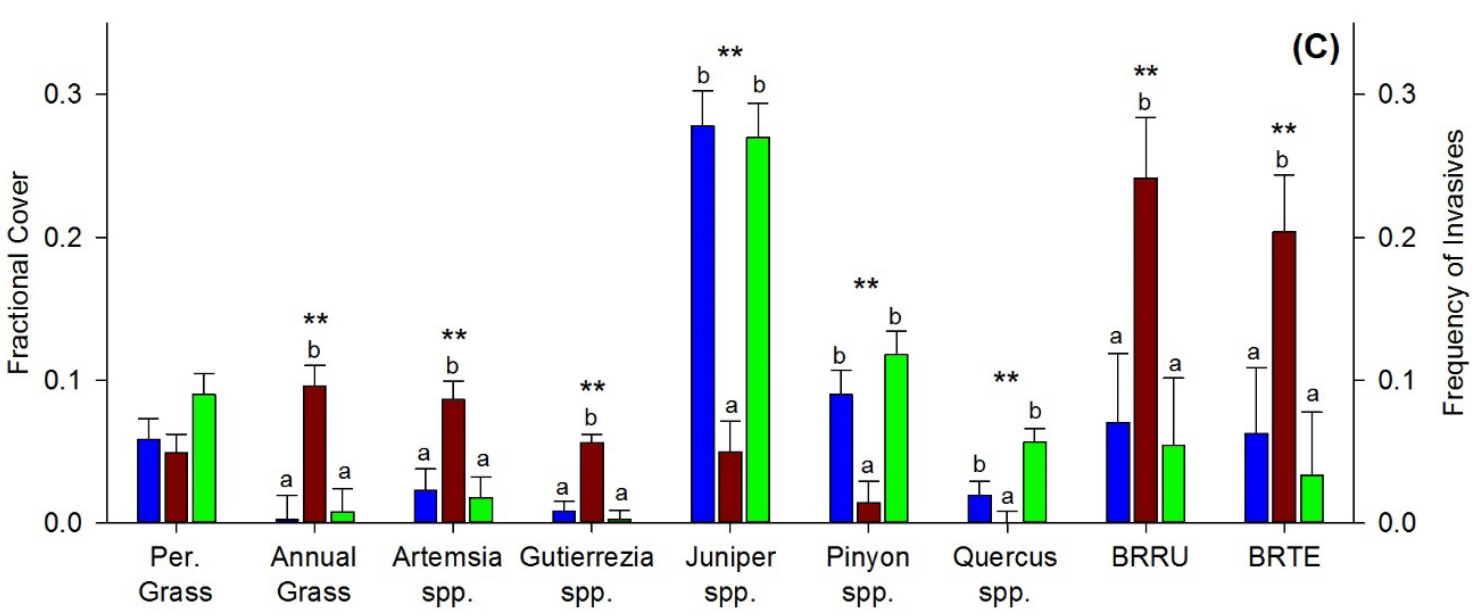

Figure 18. Plots showing fractional cover of the high desert and forest and savanna ecological site groups. See figure 6 and table 6 for more information. $A$, Soil and hydrologic function indicators; $B$, plant community functional group cover; and $C$, dominant species cover and invasive species frequency. ${ }^{*}$ indicates $p<0.10$; ${ }^{*}$ indicates $p<0.05$ for ecological site group differences from mixed model analysis of variance. Where analysis of variance detected differences among ecological site groups, bars with the same letter $(a, b$, or $c)$ do not differ. BSC, biological soil crust; per., perennial; BRRU, Bromus rubens; BRTE, Bromus tectorum. 


\begin{tabular}{|c|c|c|c|c|c|c|c|c|c|c|c|c|c|c|c|c|c|c|c|c|c|}
\hline \multirow[b]{2}{*}{ Indicators } & \multicolumn{6}{|c|}{ Landscape setting } & \multicolumn{10}{|c|}{ Soil surface properties } & \multicolumn{2}{|c|}{ Cattle } & \multicolumn{3}{|c|}{ Soil Classes } \\
\hline & Elev. & TWI & $\begin{array}{l}\text { Flow } \\
\text { Acc. }\end{array}$ & Slope & $\begin{array}{l}\text { Curv- } \\
\text { ature }\end{array}$ & $\begin{array}{l}\text { Solar } \\
\text { Insol }\end{array}$ & $\begin{array}{l}\text { Bed- } \\
\text { rock }\end{array}$ & $\begin{array}{l}\text { Cob- } \\
\text { ble }\end{array}$ & $\begin{array}{l}\text { Gra- } \\
\text { vel }\end{array}$ & $\begin{array}{l}\text { All } \\
\text { Rock }\end{array}$ & $\begin{array}{l}\text { A-Hor. } \\
\text { Frag. }\end{array}$ & Sand & Clay & $\begin{array}{l}\text { Sat. } \\
\text { Con }\end{array}$ & AWC & $\begin{array}{l}\text { Field } \\
\text { Cap }\end{array}$ & $\begin{array}{l}\text { Cow } \\
\text { Dung }\end{array}$ & $\begin{array}{l}\text { Dist. } \\
\text { Water }\end{array}$ & $\begin{array}{l}\text { Dep- } \\
\text { th }\end{array}$ & $\begin{array}{l}\text { Tex- } \\
\text { ture }\end{array}$ & $\begin{array}{l}\text { Soil } \\
\text { Tax. }\end{array}$ \\
\hline \multicolumn{22}{|c|}{ Site stability and hyrdologic funcfon } \\
\hline Basal Gaps & -0.05 & 0.21 & 0.08 & -0.16 & 0.04 & 0.11 & 0.01 & 0.02 & 0.06 & 0.04 & 0.08 & -0.15 & 0.11 & -0.14 & 0.15 & 0.13 & -0.05 & 0.05 & 0.29 & 0.62 & 0.87 \\
\hline Canopy Gaps & -0.33 & 0.14 & 0.01 & -0.05 & 0.26 & -0.09 & 0.25 & -0.08 & 0.19 & 0.14 & -0.01 & 0.28 & -0.21 & 0.23 & -0.28 & -0.24 & 0.18 & 0.04 & 0.23 & 0.31 & 0.02 \\
\hline Bare Ground & 0.06 & 0.51 & 0.33 & -0.41 & -0.14 & 0.30 & -0.29 & -0.27 & -0.45 & -0.53 & -0.34 & 0.13 & -0.05 & 0.11 & -0.16 & -0.09 & 0.22 & -0.18 & 0.05 & 0.42 & 0.57 \\
\hline Ground Cover & 0.31 & -0.22 & -0.11 & 0.22 & -0.21 & -0.01 & -0.01 & 0.32 & 0.43 & 0.47 & 0.29 & -0.25 & 0.11 & -0.20 & 0.30 & 0.18 & -0.32 & 0.05 & 0.84 & 0.09 & 0.16 \\
\hline BSC & -0.19 & 0.12 & 0.11 & -0.07 & 0.31 & -0.03 & 0.03 & -0.24 & -0.14 & -0.24 & -0.10 & 0.08 & -0.11 & 0.06 & -0.04 & -0.09 & 0.03 & -0.15 & 0.13 & 0.78 & 0.71 \\
\hline Lichens & -0.02 & 0.11 & 0.08 & -0.14 & 0.01 & 0.09 & -0.08 & -0.22 & 0.06 & -0.11 & -0.07 & -0.08 & -0.02 & -0.08 & 0.16 & 0.03 & -0.04 & -0.19 & 0.26 & 0.28 & 1.00 \\
\hline Moss & -0.20 & 0.13 & 0.13 & -0.06 & 0.22 & -0.06 & -0.01 & -0.18 & -0.22 & -0.25 & -0.08 & 0.14 & -0.08 & 0.08 & -0.14 & -0. & .01 & -0.17 & 0.43 & 0.74 & 0.48 \\
\hline Litter & 0.48 & 0.04 & -0.09 & -0.24 & -0.22 & 0.33 & -0.28 & -0 & -0.23 & -0.35 & -0.02 & -0.39 & 0.29 & -0.28 & 0.36 & 33 & 0.12 & -0.09 & 0.83 & 0.02 & 0.00 \\
\hline & & -0.14 & -0.09 & & 0.18 & 0.03 & 0.02 & 0.32 & -0.03 & 0.15 & -0.17 & -0.06 & -0.10 & -0.10 & 20 & -0 & .12 & 0.03 & 0.20 & 0.00 & 0.20 \\
\hline \multicolumn{22}{|c|}{ Plant diversity and funcfonal groups } \\
\hline Diversity & 0.05 & -0.26 & -0.28 & 0.11 & 0.05 & -0.09 & 0.17 & -0.06 & -0.19 & -0.10 & 0.22 & -0.18 & 0.19 & -0.20 & 0.14 & & 0.12 & 0.01 & 0.56 & 0.34 & 0.29 \\
\hline Total & 0.30 & -0.24 & -0.10 & 0.18 & -0.12 & 0.00 & -0.04 & 0.08 & 0.02 & 0.05 & 0.13 & -0.37 & 0.26 & -0.32 & 36 & & 0.14 & 0.17 & 0.96 & 0.04 & 0.00 \\
\hline Woody & 0.56 & 0.02 & 0.03 & -0.07 & -0.26 & 0.27 & -0.34 & 0.11 & -0.11 & -0.09 & 0.02 & -0.43 & 0.35 & -0.39 & 0.41 & 39 & -0.40 & -0.02 & 0.23 & 0.01 & 0.00 \\
\hline Herbaceous & -0.37 & -0.40 & -0.21 & 0.36 & 0.19 & -0.40 & 0.37 & -0.08 & 0.17 & 0.16 & 0.10 & 0.12 & -0.15 & 0.14 & -0.08 & -0.14 & 0.33 & 0.25 & .09 & 0.71 & 0.12 \\
\hline Perennial & 0.53 & -0.07 & -0.01 & 0.04 & -0.25 & 0.18 & -0.28 & 0.13 & -0.08 & -0.04 & 0.04 & -0.43 & 0.34 & -0.39 & 0.41 & 39 & -0.37 & 0.01 & 36 & 0.01 & 0.00 \\
\hline Annual & -0.58 & -0.32 & -0.20 & 0.24 & 0.32 & -0.39 & 0.48 & -0.14 & 0.22 & 0.18 & 0.15 & 0.16 & -0.19 & 0.17 & -0.12 & -0. & 0.45 & 0.29 & 0.02 & 0.52 & 0.00 \\
\hline Tree & & 0.38 & 0.27 & -0.30 & -0.35 & 0.54 & -0.37 & 0.15 & -0.21 & -0.15 & -0.10 & -0.47 & 0.43 & -0.42 & 0.41 & & -0.34 & -0.10 & .04 & 0.00 & 0.00 \\
\hline Shrub & -0.54 & -0.63 & -0.41 & 0.45 & 0.18 & -0.59 & 17 & -0.12 & 0.18 & 0.11 & 0.23 & 0.22 & -0.28 & 0.18 & -0.14 & -0 & 0.06 & 0.12 & 0.17 & 0.08 & 0.00 \\
\hline Per. & 0.06 & -0.36 & -0.18 & 0.36 & -0.11 & -0.27 & 0 & 0.06 & 0.08 & 0.10 & 00 & 0. & -0.09 & 0.06 & 0.00 & -0 & -0.05 & 0.04 & 0.87 & 0.95 & 0.12 \\
\hline Ann. Grass & & -0.33 & & 0.25 & 0.33 & -0.37 & 0.51 & -0.12 & 0.10 & 0.11 & 0.18 & 0.13 & -0.17 & 0.14 & -0.09 & & 47 & & 0.01 & 0.60 & 0.00 \\
\hline \multicolumn{22}{|c|}{ Dominant species and species of concern } \\
\hline & -0.45 & -0.16 & -0.08 & 0.09 & -0.01 & -0.25 & -0.07 & 0.05 & 0.00 & 0.00 & -0.06 & 0.21 & -0.23 & 0.16 & -0.14 & -0 & 08 & 0.0 & 0.32 & 0.23 & 0.00 \\
\hline Gutierrez & -0.65 & -0.35 & -0.25 & 0.24 & 0.48 & -0.43 & 0.42 & -0.20 & 0.02 & 0.00 & 0.18 & 0.25 & -0.12 & 0.09 & -0.26 & -0. & .35 & 0.05 & 0.18 & 0.02 & 0.00 \\
\hline Juniper & 0.74 & 0.51 & 0.35 & -0.39 & -0.29 & 0.5 & -0.37 & -0.01 & -0.32 & -0.31 & -0.13 & -0.45 & 0.49 & -0.44 & 0.36 & 0. & -0.29 & -0.13 & 0.06 & 0.00 & 0.00 \\
\hline Pinyon & 0.43 & 0.00 & 0.00 & -0.06 & -0.23 & 0.21 & -0.20 & 0.26 & 0.07 & 0.13 & 0.03 & -0.28 & 0.15 & -0.18 & 0.27 & 20 & 0.26 & 0.03 & 0.17 & 0.21 & 0.02 \\
\hline Quercus & 0.31 & -0.28 & -0.21 & 0.20 & -0.14 & -0.08 & -0.17 & -0.07 & -0.12 & -0.15 & 08 & -0.06 & -0.05 & -0.03 & 0.12 & 00 & -0.18 & -0.01 & 0.98 & 0.43 & 0.00 \\
\hline BRRU & -0.48 & -0.46 & -0.28 & 0.54 & 0.49 & -0.55 & 0.59 & -0.05 & 0.43 & 0.41 & 32 & 0.05 & -0.04 & 0.03 & -0.04 & -0.04 & 0.29 & 0.33 & 0.10 & 0.98 & 0.00 \\
\hline BRTE & 0.38 & -0.20 & -0.22 & 0.01 & 0.09 & -0.20 & 0.14 & -0.19 & 0.00 & -0.08 & 0.21 & 0.20 & -0.22 & 0.18 & -0.16 & -0.2 & 0.10 & 0.08 & 0.12 & 0.33 & 0.12 \\
\hline \multicolumn{22}{|c|}{ NMS Axis Scores - High Desert } \\
\hline & & 0.62 & & & -0.39 & & -0.54 & -0.02 & -0.49 & -0.48 & -0.27 & -0.29 & 0.31 & -0.22 & & & -0.25 & -0.3 & 0.00 & 0.14 & 0.00 \\
\hline A & 0 & 0.10 & 0.04 & -0.2 & -0 . & & -0.26 & -0 . & -0.37 & -0.35 & -0.09 & 0.03 & 0.01 & -0.04 & -0.02 & & 0.05 & -0.23 & 0.23 & 0.95 & 0.00 \\
\hline Axis-3 & 0.34 & 0.00 & -0.08 & -0.22 & -0.11 & 0.31 & -0.12 & -0.12 & -0.17 & -0.21 & 0.05 & -0.35 & 0.26 & -0.23 & & & -0.05 & 0.0 & 0.99 & 0.18 & 0.18 \\
\hline \multicolumn{22}{|c|}{ NMS Axis Scores - Forest and Savanna } \\
\hline Axis-1 & & -0.56 & -0.41 & 0.39 & -0.11 & -0.5 & -0.33 & -0.49 & -0.19 & -0.57 & 0.01 & 0.18 & -0.24 & 0.27 & -0.08 & -0.2 & & 0.0 & 0.97 & 0.71 & 0.07 \\
\hline Axis-2 & -0.20 & -0.49 & -0.24 & 0.40 & 0.03 & -0.28 & -0.14 & 0.37 & 0.20 & 0.46 & 0.29 & 0.17 & -0.45 & 0.27 & 0.10 & -0.37 & & 0.12 & 0.98 & 0.07 & 0.37 \\
\hline
\end{tabular}

Figure 19. Plots showing correlations between rangeland health indicators, ordination axes (nonmetric multidimensional scaling [NMS]), and landscape setting, soil, and cattle factors for high desert and forest and savanna settings. See table 1 for descriptions of rangeland health indicators (left column) and table 5 for descriptions of edaphic factors (top row). Cell values are Pearson correlation coefficients (for continuous variables; bold values indicate $p$-values $<0.05$ ) or $p$-values from ANOVA tests (for soil classes). Cell color shading provides further emphasis on correlation strength (dark green, strong positive; yellow, near zero; and dark red, strong negative) or ANOVA $p$-value strength (dark green is strong and white is weak).

woody (tree) cover. Low elevations have a large proportion of shrubs and herbaceous species (except perennial grasses). There is also a tendency for high tree cover in hydrologically enhanced areas (high TWI and flow accumulation; more concave), whereas shrubs and herbaceous species occupy less-enhanced, more sloping locations. Woody and tree cover are also positively correlated with high solar gain (high solar insolation) whereas shrubs and herbaceous functional types (annuals, perennial grasses, and so on) tend to occur on cool aspects. The amount of exposed bedrock and soil depth are significantly associated with tree and herbaceous plant cover, but soil rockiness is not. High tree cover is associated with less exposed bedrock and deeper soils, whereas more bedrock and shallow soils favor herbaceous functional groups, including annual forbs and grasses. High surface sand content and associated hydrologic properties favor high tree cover, whereas shrubs show negative correlation with surface clay content and water retention at field capacity.

Dominant species and species of concern also show strong association with landscape position, soil properties, and soil taxonomy (fig. 19). There is high cover of Artemisia spp. and Gutierrezia spp. and high frequency of Bromus rubens and Bromus tectorum at low elevations, whereas juniper, pinyon, and Quercus spp. have high cover at high elevations. Gutierrezia spp. cover and B. rubens frequency are associated with landscape settings that shed water (low TWI and flow 
accumulation; high curvature) whereas juniper species are associated with run-in, shallow slope areas. Both Artemisia spp. and Gutierrezia spp. have high cover on cool aspects (low solar insolation), as does B. rubens. Gutierrezia spp. cover is high in locations with more exposed bedrock and sandier soils with low available water holding capacity. Juniperus spp. cover is negatively correlated with exposed bedrock and soil rockiness and positively correlated with clay content and associated hydrologic properties. Pinus spp. have a similar association with soil texture but are also positively correlated with cobble content. B. rubens is more common in sites with high exposed bedrock and high rockiness. The species level of association with soil taxonomy was notably strong in the high desert and forest and savanna climates. Artemisia and Gutierrezia spp. were most abundant on haploargids and haplocalids, respectively. Juniperus and Pinus spp. were most abundant on the various taxa characterized by mollic epipedons (argiustolls, calciustolls, and paleustolls) and Quercus spp. were most abundant on calcareous soils with a mollic epipedon (calciustolls). B. rubens was most frequent on torriorthents.

\section{Ordinations}

The cluster analysis identified three floristic groups in the high desert, two of which are characterized by shrubs (mixed shrublands and sagebrush shrublands) and one that is characterized by trees (pinyon-juniper woodlands; table 13). The final NMS has three dimensions, stress of 9.81, and instability of 0.00000 .

The mixed shrublands have the highest average richness (15.7) and the highest diversity (Simpson's diversity index of 0.84 ) of all the floristic groups, despite the small sample size $(\mathrm{N}=7)$. Woody cover is dominant $(0.25)$, but graminoid cover also composes a large portion of the cover in places (as much as 0.29 ). The woody cover is predominantly composed of shrubs (0.23), rather than trees (0.2). The graminoid cover is due in part to cover of the nonnative annual grasses Bromus rubens and Bromus tectorum. This group is characterized by B. rubens, and the native shrubs Atriplex canescens, Ephedra viridis, and Yucca baccata. Soil stability is generally low (2.12), with only two of the seven plots averaging higher than category 2 .

The sagebrush shrublands have a moderate average richness (10.6) and diversity (0.74), and more variability in the amount of total foliar cover $(0.19$ to 0.58$)$ than the mixed shrublands (table 13). This cover is largely woody cover $(0.26)$ as shrubs (0.23), but graminoid cover in the form of mostly $B$. tectorum and $B$. rubens is also a large component in some areas (ranges from 0.01 to 0.44 ). Artemisia tridentata is the primary shrub and primary indicator for this group. Additionally, B. tectorum and Sphaeralcea grossularifolia are weak indicators. Average soil stability is low to moderate with an average of 2.47 .

Pinyon-juniper woodlands have a moderate average richness (9.7), but low diversity (0.621; table 13$)$. This floristic group has high average total foliar cover $(0.46)$ but is somewhat variable. Most of the total foliar cover is accounted for by woody tree cover (0.37), as shrub (0.09), graminoid (0.04), and forb (0.02) cover are all low. Though low in cover, graminoid cover is composed of perennial grasses rather than annual nonnatives. Tree cover consists of Juniperus osteosperma and two species of pinyon (Pinus monophylla and Pinus edulis), which are also the strongest indicator species. The forb Eriogonum umbellatum, though low in cover, was primarily found with this plant assemblage and is therefore a moderate indicator.

In the high desert, we observed strong concordance between ESGs and floristic groups (table 8) and NMS axes

Table 13. Floristic groups in the high desert climate zone identified by cluster analysis and indicator species analysis.

[In addition to functional groups, species with statistically significant $(p<0.05)$ indicator values are listed, followed by indicator value in parentheses. SD, standard deviation; N, number]

\begin{tabular}{|c|c|c|c|}
\hline Indicator & Mean (SD) & Min. & Max. \\
\hline \multicolumn{4}{|c|}{ Mixed shrublands $(\mathrm{N}=7)$} \\
\hline Total foliar cover & $0.41(0.07)$ & 0.31 & 0.47 \\
\hline Woody cover & $0.25(0.08)$ & 0.15 & 0.35 \\
\hline Graminoid cover & $0.16(0.08)$ & 0.04 & 0.29 \\
\hline Annual cover & $0.13(0.09)$ & 0.01 & 0.25 \\
\hline Avg. soil stability & $2.12(1.24)$ & 1.06 & 4.28 \\
\hline Bromus rubens (74) & $0.08(0.09)$ & 0.00 & 0.25 \\
\hline Atriplex canescens (58) & $0.02(0.01)$ & 0.00 & 0.04 \\
\hline Ephedra viridis (55) & $0.03(0.02)$ & 0.00 & 0.07 \\
\hline Yucca baccata (53) & $0.02(0.01)$ & 0.00 & 0.04 \\
\hline \multicolumn{4}{|c|}{ Sagebrush shrublands $(N=16)$} \\
\hline Total foliar cover & $0.38(0.13)$ & 0.19 & 0.58 \\
\hline Woody cover & $0.26(0.08)$ & 0.15 & 0.41 \\
\hline Graminoid cover & $0.16(0.13)$ & 0.01 & 0.44 \\
\hline Annual cover & $0.11(0.13)$ & 0.00 & 0.41 \\
\hline Avg. soil stability & $2.47(0.93)$ & 1.17 & 4.29 \\
\hline Artemisia tridentata (84) & $0.14(0.08)$ & 0.03 & 0.34 \\
\hline Bromus tectorum (49) & $0.07(0.08)$ & 0.00 & 0.24 \\
\hline $\begin{array}{l}\text { Sphaeralcea grossularifolia } \\
\text { (41) }\end{array}$ & $0.01(0.02)$ & 0.00 & 0.05 \\
\hline \multicolumn{4}{|c|}{ Pinyon-juniper woodland ( $N=19)$} \\
\hline Total foliar cover & $0.46(0.11)$ & 0.25 & 0.71 \\
\hline Woody cover & $0.43(0.11)$ & 0.25 & 0.71 \\
\hline Graminoid cover & $0.04(0.05)$ & 0.00 & 0.17 \\
\hline Annual cover & $0.00(0.00)$ & 0.00 & 0.01 \\
\hline Avg. soil stability & $2.60(0.96)$ & 1.33 & 4.94 \\
\hline Juniperus osteosperma (80) & $0.30(0.10)$ & 0.10 & 0.43 \\
\hline Pinus monophylla (79) & $0.06(0.07)$ & 0.00 & 0.27 \\
\hline Pinus edulis (63) & $0.05(0.06)$ & 0.00 & 0.26 \\
\hline Eriogonum umbellatum (53) & $0.00(0.01)$ & 0.00 & 0.02 \\
\hline
\end{tabular}


(fig. 19). The deep basalt ESG was almost exclusively classified by the cluster analysis as a pinyon-juniper woodland. The shallow limestone ESG has both the mixed shrubland and sagebrush shrubland clusters (table 8). Several landscape and soil factors were strongly correlated with the first NMS axis but fewer significant correlations were found with the second and third axes (fig. 19). Axis-1 is positively correlated with high elevations, run-in topographic settings (high TWI and flow accumulation, shallow slope and curvature), and warm aspects (high solar insolation). Axis-1 is also negatively correlated with soil rockiness (amount of exposed bedrock, gravel cover, and all rock cover) and positively correlated with soil clay content. Axis-2 shows no correlation with landscape metrics but, like axis-1, is negatively correlated with rockiness (gravel cover and all rock cover). Axis-3 is also positively correlated with elevation and solar insolation but negatively correlated with surface sand content and available water capacity.

Three groups were identified within the forest and savanna climate zone (table 14). Two of the groups are typified by different tree species with little understory (pinyon woodlands and juniper woodlands), whereas the third has a dense shrubby understory (forest shrublands). The final NMS has two dimensions, stress of 11.86 , and instability of 0.00000 .

The pinyon woodlands have low average richness (7.2) and low diversity (0.65), similar to the pinyon-juniper woodlands. The high average total foliar cover $(0.50)$ is composed mostly of woody cover $(0.47)$, especially trees (0.37). This group does have some shrub cover (0.14), particularly Artemisia tridentata. Annual cover is negligible (0.01), so most of the graminoid cover (0.04) is attributable to perennial grasses. Pinus edulis and A. tridentata are strong indicators of this group, but Juniperus osteosperma and other shrubs do occur in smaller amounts. Soil stability is moderately stable (3.70).

The juniper woodlands have a moderate average species richness (11.2), but low diversity (0.64), similar to the pinyon-juniper woodlands and the pinyon woodlands. The high average total foliar cover $(0.52)$ is also composed mostly of woody vegetation $(0.48)$, particularly trees $(0.40)$. This group, however, generally has very little shrub understory (0.09) and is characterized by J. osteosperma. Although Pinus monophylla and P. edulis occur, they are in much smaller amounts than in the pinyon-juniper woodlands and in the pinyon woodlands. Graminoid cover $(0.07)$ is predominantly composed of the perennial Elymus elymoides. Soil stability is unstable to moderately stable (2.51), and only four of eleven plots have an average soil stability of 3 or more.

The forest shrublands, in contrast to the juniper woodlands and pinyon woodlands, have high average species richness (12.2) and diversity (0.82), despite the small sample size (N $=4)$. This group also has the highest average and overall total foliar cover of all eleven groups (0.62, ranging from 0.52 to $0.73)$. Woody cover is the dominant type (0.53), but shrub and tree cover are generally balanced $(0.26$ and 0.33 , respectively). Average graminoid cover is also higher than pinyon woodlands or juniper woodlands (0.22) and is composed mostly of perennial grasses. This group is characterized by the native perennial grass Poa fendleriana and the native shrubs Garrya flavescens, Quercus turbinella, and Purshia stansburiana. Soil stability is generally moderately stable $(>3)$, but one plot had very low average stability (1.6).

Fewer landscape and soil factors were correlated with NMS axes in the forest and shrublands than in other climate zones (fig. 19), likely partly because only one ESG is identified in this climate zone (table 8). Axis-1 is negatively correlated with run-in positions (TWI), incoming solar gain (solar insolation), and soil rockiness (cobbles and total rock cover). Axis-2 is negatively correlated with run-in position (TWI) but is positively correlated with soil rockiness (total rock cover).

Across the high desert and forest and savanna field plots, there is no association between plant diversity and soil variables measured and very little association between

Table 14. Floristic groups in the forest and savanna climate zone identified by cluster analysis and indicator species analysis.

[In addition to functional groups, species with statistically significant $(p<0.05)$ indicator values are listed, followed by indicator value in parentheses. SD, standard deviation; $\mathrm{N}$, number]

\begin{tabular}{|c|c|c|c|}
\hline Indicator & Mean (SD) & Min. & Max. \\
\hline \multicolumn{4}{|c|}{ Pinyon woodlands $(\mathrm{N}=4)$} \\
\hline Total foliar cover & $0.50(0.06)$ & 0.44 & 0.56 \\
\hline Woody cover & $0.47(0.06)$ & 0.43 & 0.56 \\
\hline Graminoid cover & $0.04(0.07)$ & 0.00 & 0.15 \\
\hline Annual cover & $0.01(0.02)$ & 0.00 & 0.03 \\
\hline Avg. soil stability & $3.70(1.17)$ & 2.13 & 4.61 \\
\hline Pinus edulis (80) & $0.24(0.11)$ & 0.09 & 0.33 \\
\hline Artemisia tridentata (77) & $0.05(0.05)$ & 0.01 & 0.11 \\
\hline \multicolumn{4}{|c|}{ Juniper woodlands ( $N=11)$} \\
\hline Total foliar cover & $0.52(0.08)$ & 0.39 & 0.67 \\
\hline Woody cover & $0.48(0.09)$ & 0.31 & 0.63 \\
\hline Graminoid cover & $0.07(0.05)$ & 0.00 & 0.13 \\
\hline Annual cover & $0.01(0.01)$ & 0.00 & 0.03 \\
\hline Avg. soil stability & $2.51(0.91)$ & 1.12 & 4.28 \\
\hline Elymus elymoides (75) & $0.02(0.02)$ & 0.00 & 0.07 \\
\hline Juniperus osteosperma (52) & $0.34(0.08)$ & 0.19 & 0.50 \\
\hline \multicolumn{4}{|c|}{ Forest shrubland $(\mathrm{N}=4)$} \\
\hline Total foliar cover & $0.62(0.09)$ & 0.52 & 0.73 \\
\hline Woody cover & $0.53(0.10)$ & 0.41 & 0.65 \\
\hline Graminoid cover & $0.22(0.04)$ & 0.17 & 0.27 \\
\hline Annual cover & $0.00(0.01)$ & 0.00 & 0.01 \\
\hline Avg. soil stability & $3.33(1.24)$ & 1.56 & 4.33 \\
\hline Poa fendleriana (79) & $0.19(0.07)$ & 0.13 & 0.27 \\
\hline Garrya flavescens (72) & $0.04(0.04)$ & 0.00 & 0.09 \\
\hline Quercus turbinella (67) & $0.13(0.05)$ & 0.09 & 0.21 \\
\hline Purshia stansburiana (59) & $0.04(0.02)$ & 0.02 & 0.07 \\
\hline
\end{tabular}


diversity and landscape factors (fig. 19). The only significant correlation detected suggest locations that are hydrologically enhanced (high TWI and flow accumulation) are characterized by low diversity.

\section{Discussion}

\section{Patterns in Rangeland Health Indicators}

The results presented here contribute to regional- and national-scale efforts aimed at developing robust conceptual models regarding the role soil, topographic, and climate properties play in controlling ecosystem resilience and vulnerability to land use and climate change (Steele and others, 2012; Bestelmeyer and others, 2016; Williamson and others, 2016). Organizing landscapes based on contextual information that (1) is generally static under managementrelevant time frames and (2) groups landscape units based on ecosystem response to management and climate provides a useful framework for management actions, policy decisions, as well as ecological investigations (Duniway, Bestelmeyer, and others, 2010).

In the NPS-managed portions of the Grand CanyonParashant National Monument surveyed here (fig. 1), elevation gradients explain much of the broad-scale variation in soil and vegetation indicators, and associated rangeland health interpretations. Broad trends suggest a decrease in erosion risk with increasing elevation because of increasing vegetation cover, including a strong linear decrease in the cover of large canopy gaps and increase in litter cover (fig. 8A; Okin, 2008). However, other indicators that are important for soil and site stability and hydrologic function (table 1) either do not have strong elevational trends (for example, bare ground) or have trends that suggest decreasing function with elevation (for example, soil stability; Pellant and others, 2005).

There are few strong associations between plant functional groups and elevation (with trees being the exception; fig. $9 A$ ), but there are strong species-level climate associations. This suggests that species turnover across elevation zones may represent species differences in adaptation to climates (fig. 9B). For example, there is a shift in the dominant shrub from Ambrosia dumosa in the low elevations to Coleogyne ramosissima in the middle elevations to Artemisia spp. in the high elevations. Upper limits for Larrea tridentata and C. ramosissima are likely attributable to temperature limits and freeze sensitivity (Beatley, 1974; Meyer and Pendleton, 2005), whereas the lower elevation boundaries for both C. ramosissima and Artemisia spp. likely represent a low aridity tolerance (Meyer and Pendleton, 2005; Schlaepfer and others, 2011). Similarly, the lower limit for Juniperus spp. is also likely governed by aridity. The upper limits of Artemisia spp. observed here are below known elevation and climate limits of Artemisia spp., which can likely be attributed to the increase of Juniperus spp. Increases in juniper and pinyon species cover into historic sagebrush shrublands and consequent decrease in other species is a common phenomenon observed across the western United States (McArthur and Plummer, 1978). Several of the plots recorded here, particularly in the pinyon-juniper woodland, pinyon woodland, and juniper woodland floristic groups likely represent some level of tree encroachment (table 7; van Auken, 2000).

\section{Invasive Species}

Invasive Bromus species are of great management concern in the intermountain west, primarily because of the increase in fire frequency associated with Bromus invasions (Beatley, 1966; Balch and others, 2013). However, distributions of these species are likely to shift in response to climate change (Abatzoglou and Kolden, 2011). In particular, Bromus rubens is likely to move up-slope, into areas where its distribution has been historically cold limited (Bradley and others, 2016). $B$. rubens is the most frequent invasive species of concern recorded in this study (fig. 9C), with a clear upper elevation limit (strong negative correlation with elevation in the high desert and forest and savanna climate zones; fig. 19). Forecasts for increasing temperatures in the southwestern United States (Garfin, 2014) suggest $B$. rubens may move to higher elevations of Grand Canyon-Parashant National Monument in coming decades. Soil associations from the middle desert suggest areas with higher risk of $B$. rubens are rocky soils with fine textures of the nonrock soil fraction (fig. 16).

Schismus arabicus and Erodium cicutarium are also nonnative species of concern because of altered fire regimes and competition with native species (Brooks, 1999a, 2000; Steers and Allen, 2010). In this study, S. arabicus was more abundant in the low elevations with a strong negative correlation with elevation and an affinity for run-in locations, sites close to livestock water sources, and coarse soils (figs. $9 C, 16$ ), which agrees with observations in previous studies (Brooks, 1999b). E. cicutarium was found in both the low and middle deserts (fig. 9C) but showed little association with soil or landscape properties (figs. 16, 19). Similar to concerns regarding $B$. rubens, it is likely that $S$. arabicus will increase in frequency at high elevations as temperatures warm.

\section{Soils, Topography, and Ecosystems}

The effect of the combination of climate, topography, and soils on ecosystem properties and processes, including resistance and resilience to drivers of change, is referred to as "ecological potential" or "land potential" (Caudle and others, 2013; Bestelmeyer and others, 2015). The NRCS ecological site system is a land classification system based on concepts of ecological potential. Sites are differentiated primarily by climate, soil depth, soil rockiness, soil texture, soil mineralogy, 
and site topographic setting (Duniway, Bestelmeyer, and others, 2010). Spatial information on ecological sites is provided through soil survey map units (Duniway, Bestelmeyer, and others, 2010). However, ecological site information is not yet standardized and available for all lands, leading to efforts to standardize methodologies (Caudle and others, 2013). Many ecological site descriptions (ESDs) with associated state-and-transition models are not yet complete for soil units in Grand Canyon-Parashant National Monument (Lindsay and others, 2003; Natural Resources Conservation Service, 2018). A proposed approach to streamline development of robust and data-driven ESDs is to create more generalized groups that fit within hierarchical classes (Bestelmeyer and others, 2016; Duniway and others, 2016; Salley and others, 2016). Indeed, it is fairly common to group ecological sites when using them to understand impacts of management on large heterogeneous landscapes (Duniway and Herrick, 2013; Munson and others, 2016).

Here, we organized the 31 ecological sites we encountered into 10 ecological site groups (ESGs; table 6). These aggregations of ESDs (1-5 ESDs per group) explain important variability in the distribution of plant communities (strong correlation between ESGs and floristic groups; table 8 ) and many indicators of rangeland health were found to vary systematically among ESGs (figs. 12, 15, 18), although the amount of indicator variation explained by ESGs varies greatly across climate zones. In the low desert, little differentiation in floristic groups was identified between the two non-gypsiferous ESGs (table 8). In the middle and high desert zones, there was generally strong concordance between ESGs and floristic groups. The two shallow ESGs were dominated by blackbrush shrublands floristic groups and the majority of plots in the two deep ESGs were classified as desert grasslands in the ordination. This pattern of shallow soils supporting shrubland communities and deeper soils supporting perennial grasslands follows patterns observed in other areas of the Colorado Plateau (Duniway and others, 2016). We also see a pattern of shrublands (sagebrush and mixed shrubland) in the shallow ESGs in the high desert, however, in contrast to the middle desert, deep soil settings in the high desert support pinyon-juniper woodlands (table 8). In some areas of the Colorado Plateau, sites with deep soil dominated by pinyon-juniper woodlands indicate woody expansion and departure from reference conditions (van Auken, 2000; Duniway and others, 2016).

In addition to concordance of ecosystem condition and ESGs, individual soil and landscape properties were also shown to have a strong control on plant communities and rangeland condition in many instances (McAuliffe, 1994; Duniway, Bestelmeyer, and others, 2010; Munson and others, 2015). The soil and landscape variables found to be important in governing rangeland conditions are consistent with other dryland plant-soil relations frameworks (Duniway, Bestelmeyer, and others, 2010): elevation, topographic setting (run-in/run-off characteristics, slope, aspect), amount of exposed bedrock, soil rockiness, soil texture (and associated hydrologic properties), and soil depth (figs. 13, 16, 19). There is variation in the relative importance of soil and landscape properties among climate zones and attributes of rangeland health. For example, landscape setting variables are less correlated with the ordination axis scores in the middle desert (fig. 16) than any of the other climate zones (figs. 13, 19), suggesting a low importance of topographic setting in the middle desert. Similarly, associations between plant functional group cover and soil and landscape properties varied between climate zones, with woody species showing strong associations in the low desert, high desert, and forest and savanna zones and primarily herbaceous functional groups displaying significant correlations in the middle desert.

Interestingly, cover of woody species displayed essentially opposite associations with soil texture in the lower than higher climate zones, with woody cover greater on welldrained sandy soils in the low desert versus finer textured and higher water-holding-capacity soils in the upper elevations. This inverse association of texture along an aridity gradient has been demonstrated in other studies (Sala and others, 1988 ) and is thought to be due to the shifting importance of evaporative loss from the soil surface between arid and more mesic climates. Tree species cover, primarily Juniperus spp., was also high in run-in locations in the high desert and forest and savanna climate zones (fig. 19). Other work assessing topographic relations and woody encroachment has found that areas with high TWI were more susceptible to woody encroachment (Ben Wu and Archer, 2005). However, more work is needed in the Grand Canyon-Parashant National Monument pinyon-juniper woodlands to establish which woodlands are near reference condition and which represent an alternative state of a shrubland or more open savanna (Archer and others, 2017).

\section{Evidence of Cattle Impacts}

Grazing by domestic livestock is one of the most widespread land-use types in the region (Copeland and others, 2017) and has been shown to affect dryland ecosystems both directly, through selective herbivory and hoof impacts, and indirectly via feedbacks with ecosystem processes, such as plant competition and plant-soil feedbacks (Branson and others, 1981; Warren and others, 1986; Fleischner, 1994). Observations from this study support previous work demonstrating that grazing in drylands can lead to increases in bare ground and decreases in ground cover (Turner, 1971; Miller, 2008; Duniway and others, 2018). Here, we observed more bare ground and less ground cover in areas with high evidence of cattle use (figs. 13, 16, 19), suggesting reduced hydrologic function and soil and site stability with increased cattle activity (Pellant and others, 2005), including increased run-off and water erosion (Lusby, 1970; Branson and others, 1981). Of added concern with loss of protective vegetative and ground cover in arid rangeland is risk of accelerated wind 
erosion and consequent dust emissions, which has been shown to increase in areas with heavy livestock use (Nauman and others, 2018).

In general, improper grazing reduces overall vegetative cover and can alter vegetation composition, favoring unpalatable species and introduction of invasive species (Fleischner, 1994). In the survey results presented here, correlations between biotic integrity indicators and likely cattle use provide some evidence of these negative cattle impacts on Grand Canyon-Parashant National Monument allotments. The biotic integrity indicators that are of concern are Schismus arabicus in the low desert (increased frequency close to livestock water sources; fig. 13); decreases in Coleogyne ramosissima and Ephedra spp. with indicators of cattle use in the middle desert (fig. 16); and increases in Gutierrezia spp. (a species that commonly increases with livestock grazing pressure) with cattle indicators in all of the high-elevation areas (figs. 16, 19). Similar to what was observed here, Schismus arabicus has been shown to be more abundant in more disturbed areas in the western Mojave Desert (Brooks, 1999b). Evaluation of C. ramosissima communities across a grazing gradient east of the study area (in and around Glen Canyon National Recreation Area) also showed decreases in C. ramosissima with increased grazing (Jeffries and Klopatek, 1987). However, the correlations between distance to water and $C$. ramosissima cover observed here are potentially confounded by the strong affinity of $C$. ramosissima for the shallow mixed ESG (fig. 14), which tends to occur farther from water (fig. 13). However, reduction of shrubs in winter-use shrub-dominated allotments has been observed in the region (Munson and others, 2016) and livestock are known to browse on shrubs to meet nutrient demands (Cook and others, 1954).

It is noteworthy that we did not find evidence of cattle impacts on perennial grasses, given their importance as livestock forage. We attribute this to (1) generally low cover of perennial grasses in the study area (except for the deep limestone ESG in the middle desert; fig. 15), (2) winter use in many of the allotments where grazing is most prevalent (table 2); and (3) stocking rates well below what is permitted (in most instances; table 2). Indeed, correlations between dung frequency and perennial grass within the deep limestone ESG suggests a negative trend $(r=-0.45, p=0.058)$.

The dung frequency and distance from water approach used here to examine cattle impacts on Grand CanyonParashant National Monument allotments is essentially evaluating the role livestock distribution within pastures may play in allotment rangeland conditions, and the results described above suggest that cattle distribution in Grand Canyon-Parashant National Monument allotments could be better managed. Careful livestock distribution is one of the primary mechanisms for improving the health of western rangelands (Bailey and Rittenhouse, 1989). Several methods have been suggested for obtaining a more uniform distribution. Creating smaller pastures can help with achieving a more even distribution (Hart and others, 1993), though this may not be feasible given the remote and rugged nature of Grand CanyonParashant National Monument and the requirement of frequent movement of herds between pastures. Use of supplements has been shown to be successful to increase use of underutilized areas in large and rugged pastures in Montana (as much as $600 \mathrm{~m}$ from supplements; Derek and others, 2001), though other studies using salting stations did not find success in addressing serious livestock distribution problems in large pastures of an arid rangeland (Ganskopp, 2001). A potential long-term solution could be a breed change. Heritage breeds of cattle (for example, Raramuri Criollo cattle; Anderson and others, 2015) have been shown to have better distribution in large arid pastures when compared to the English breeds typically used by ranchers in the United States, with the largest differences observed where green forage is scarce (Peinetti and others, 2011; Spiegal and others, 2019).

Warming and drying predicted for the Desert Southwest will likely further decrease vegetative cover and exacerbate risk to rangeland ecosystems (Seager and others, 2007; Munson and others, 2011; Hoover and others, 2015). Furthermore, increased aridity and severity of drought will heighten risks of improper livestock management, particularly risk to wind erosion (Duniway and others, 2019). The results presented here suggest some improvements to livestock distribution are needed in the Grand CanyonParashant National Monument. However, our study did not include evaluation of areas without grazing (long-term exclosures), which can provide a valuable reference for better understanding rangeland condition in the absence of livestock (for example, Duniway and others, 2018). Additionally, our study relied on coarse proxies of cattle use (dung frequency and cost-distance to water). Better understanding of how cattle are distributed and their behaviors in different areas (that is, trailing versus grazing) would greatly increase our understanding of their impacts on Grand Canyon-Parashant National Monument allotments, such as the types of data available from modern GPS tracking collars (Ungar and others, 2005). Finally, these results support rangeland monitoring and assessment programs that collect indicators of soil and site stability (bare ground and ground cover) and do not rely solely on vegetation composition indicators to assess livestock management (Pellant and others, 2005; Toevs and others, 2011).

\section{Conclusion}

The Grand Canyon-Parashant National Monument was established on January 11, 2000, to preserve the monument's biologically diversity, "impressive landscape," and an "array of scientific and historic objects." In this survey of 155 plots across the NPS-managed portions of the monument, we document a wide array of soils types, plant species, and communities, including 15 unique soil taxa (to great group level) and 271 plant species. We collected three new plant species for Grand Canyon-Parashant National Monument 
and 17 new species for the NPS portion of the monument. We also demonstrate strong association between rangeland health indicators and plant community types with elevation, topographic setting, and soils. These results support the management of Grand Canyon-Parashant National Monument lands using land classifications based on concepts of land potential, such as NRCS ecological sites. However, given the tremendous size of Grand Canyon-Parashant National Monument and large number of ESDs present (based on the soil survey), we also suggest using groups of ecological sites for broad management questions, as was done here. There are existing efforts to formalize ecological site groups regionally that may facilitate Grand Canyon-Parashant National Monument management (Bestelmeyer and others, 2016; Duniway and others, 2016). Additionally, recent improvements in digital soil mapping may allow improved maps of ESGs for the monument (Maynard and Karl, 2017; Ramcharan and others, 2018; Maynard and others, 2019).

The large area, rugged terrain, and remote nature of the Grand Canyon-Parashant National Monument makes access for field sampling of rangeland health indicators challenging and costly. Developments in satellite-based remote sensing of indicators may improve the efficiency of monitoring in Grand Canyon-Parashant National Monument (Jones and others, 2018; Poitras and others, 2018), particularly if monitoring methods employed are compatible with other national-level programs (as was done here). Additionally, classification of field plots into ecological sites that are linked to state-andtransition models (Miller and others, 2011) can then be used to train remote-sensing-based classifications of landscapes into putative ecological states (Poitras and others, 2018). Such maps, coupled with ecological site (or group) maps, can then be used for landscape-scale management actions (Steele and others, 2012) or to understand climate sensitivities (Bunting and others, 2017; Thoma and others, 2018).

Based on the above, the next steps for a rangeland health monitoring program for the Grand Canyon-Parashant National Monument are: (1) integrate the ecological site groups developed here with regional grouping efforts and use these as a basis for monitoring; (2) leverage new digital soil mapping workflows and products to create more precise and accurate spatial depiction of ESGs; (3) develop a rangeland health monitoring strategy that leverages field and remote-sensingbased measures; and (4) utilize decision frameworks, such as state-and-transition models, for interpreting monitoring results and guiding management objectives. In this project, developing the ecological site groups for analysis and developing new themes and maps for sample design required significant expertise and resources. Completing steps 1 and 2 above would streamline this for future assessments. Our ability to address study objectives was also limited by the high travel costs and difficult access for field work in Grand Canyon-Parashant National Monument. Incorporating remote sensing indicators (step 3) to expand sampling to remote areas (such as Lone Mountain) in future assessments will represent a substantial improvement. Finally, contextualizing assessments relative to known ecological processes and management goals is necessary for using rangeland assessments in decisionmaking processes. Development of group-level state-andtransition models (step 4) is one approach for translating assessment results into management decisions. Importantly, the data and interpretations from the 155 plots presented here are a valuable resource for achieving these next steps and will help Grand Canyon-Parashant National Monument staff better address potential threats to monument resources, including invasive species, unsustainable grazing by domestic livestock, and climate change.

\section{References Cited}

Abatzoglou, J.T., and Kolden, C.A., 2011, Climate change in Western US deserts-Potential for increased wildfire and invasive annual grasses: Rangeland Ecology \& Management, v. 64, no. 5, p. 471-478.

Anderson, D.M., Estell, R.E., Gonzalez, A.L., Cibils, A.F., and Torell, L.A., 2015, Criollo cattle-Heritage genetics for arid landscapes: Rangelands, v. 37, no. 2, p. 62-67.

Archer, S.R., Andersen, E.M., Predick, K.I., Schwinning, S., Steidl, R.J., and Woods, S.R., 2017, Woody plant encroachment - Causes and consequences, in Briske, D.D., ed., Rangeland Systems_-Processes, Management and Challenges: Cham, Springer Series on Environmental Management, p. 25-84.

Archer, S., and Stokes, C., 2000, Stress, disturbance and change in rangeland ecosystems, in Arnalds, O., and Archer, S., eds., Rangeland Desertification, Advances in Vegetation Science: Springer, v. 19, p. 17-38.

Augustine, D.J., 2003, Long-term, livestock-mediated redistribution of nitrogen and phosphorus in an East African savanna: Journal of Applied Ecology, v. 40, no. 1, p. 137-149.

van Auken, O.W., 2000, Shrub invasions of North American semiarid grasslands: Annual Review of Ecology and Systematics, v. 31, p. 197-215.

Bailey, D.W., Gross, J.E., Laca, E.A., Rittenhouse, L.R., Coughenour, M.B., Swift, D.M., and Sims, P.L., 1996, Mechanisms that result in large herbivore grazing distribution patterns: Journal of Range Management, v. 49, no. 5, p. 386-400.

Bailey, D.W., and Rittenhouse, L.R., 1989, Management of cattle distribution: Rangelands, v. 11, p. 159-161.

Balch, J.K., Bradley, B.A., D’Antonio, C.M., and GomezDans, J., 2013, Introduced annual grass increases regional fire activity across the arid western USA (1980-2009): Global Change Biology, v. 19, no. 1, p. 173-183.

Beatley, J.C., 1966, Ecological status of introduced brome grasses (Bromus Spp.) in desert vegetation of southern Nevada: Ecology, v. 47, no. 4, p. 548-554. 
Beatley, J.C., 1974, Effects of rainfall and temperature on the distribution and behavior of Larrea tridentata (creosotebush) in the Mojave Desert of Nevada: Ecology, v. 55, no. 2, p. 245-261.

Ben Wu, X., and Archer, S.R., 2005, Scale-dependent influence of topography-based hydrologic features on patterns of woody plant encroachment in savanna landscapes: Landscape Ecology, v. 20, no. 6, p. 733-742.

Bestelmeyer, B.T., Duniway, M.C., James, D.K., Burkett, L.M., and Havstad, K.M., 2013, A test of critical thresholds and their indicators in a desertification-prone ecosystemMore resilience than we thought: Ecology Letters, v. 16, no. 3, p. 339-345.

Bestelmeyer, B.T., Okin, G.S., Duniway, M.C., Archer, S.R., Sayre, N.F., Williamson, J.C., and Herrick, J.E., 2015, Desertification, land use, and the transformation of global drylands: Frontiers in Ecology and the Environment, v. 13, no. 1 , p. 28-36.

Bestelmeyer, B.T., Williamson, J.C., Talbot, C.J., Cates, G.W., Duniway, M.C., and Brown, J.R., 2016, Improving the effectiveness of ecological site descriptions: General State-and-transition models and the Ecosystem Dynamics Interpretive Tool (EDIT): Rangelands, v. 38, no. 6, p. 329-335.

Billingsley, G.H., Beard, L.S., Priest, S.S., Wellmeyer, J.L., and Block, D.L., 2004, Geologic map of the Lower Grand Wash cliffs and vicinity, Mohave County, Northwestern Arizona: U.S. Geological Survey Miscellaneous Field Studies Map MF-2427, 1 sheet, 23 p.

Bradley, B.A., Curtis, C.A., and Chambers, J.C., 2016, Bromus response to climate and projected changes with climate change, in Germino, M.J., Chambers, J.C., and Brown, C.S., eds., Exotic brome-grasses in arid and semiarid ecosystems of the western US - Causes, consequences, and management implications: Cham, Springer Series on Environmental Management, p. 257274.

Branson, F.A., Gifford, G.F., Renard, K.G., and Hadley, R.F., 1981, Rangeland Hydrology (2d ed.): Dubuque, Iowa, Kendall/Hunt Publishing Company, 340 p.

Brock, B.L., and Owensby, C.E., 2000, Predictive models for grazing distribution-A GIS approach: Journal of Range Management, v. 53, no. 1, p. 39-46.

Brooks, M.L., 1999a, Alien annual grasses and fire in the Mojave desert: Madroño, v. 46, no. 1, p. 13-19.

Brooks, M.L., 1999b, Habitat invasibility and dominance by alien annual plants in the western Mojave Desert: Biological Invasions, v. 1, no. 4, p. 325-337.

Brooks, M.L., 2000, Competition between alien annual grasses and native annual plants in the Mojave Desert: The American Midland Naturalist, v. 144, 17 p.
Bunting, E.L., Munson, S.M., and Villarreal, M.L., 2017, Climate legacy and lag effects on dryland plant communities in the southwestern U.S: Ecological Indicators, v. 74, p. 216-229.

Cade, B.S., and Noon, B.R., 2003, A gentle introduction to quantile regression for ecologists: Frontiers in Ecology and the Environment, v. 1, no. 8, p. 412-420.

Caudle, D., Sanchez, H., DiBenedetto, J., Talbot, C.J., and Karl, M.S., 2013, Interagency ecological site handbook for rangelands: U.S. Department of the Interior, $109 \mathrm{p}$.

Cook, C.W., Stoddart, L.A., and Harris, L.E., 1954, The nutritive value of winter range plants in the Great Basin as determined with digestion trials with sheep: Utah Agricultural Experiment Station Bulletin no. 372, 56 p.

Copeland, S.M., Bradford, J.B., Duniway, M.C., and Schuster, R.M., 2017, Potential impacts of overlapping land-use and climate in a sensitive dryland-A case study of the Colorado Plateau, USA: Ecosphere, v. 8, no. 5, 25 p.

Courtright, E.M., and Van Zee, J.W., 2011, The database for inventory, monitoring, and assessment (DIMA): Rangelands, v. 33, no. 4, p. 21-26.

Derek, W.B., Welling, G.R., and Eric, T.M., 2001, Cattle Use of foothills rangeland near dehydrated molasses supplement: Journal of Range Management, v. 54, no. 4, p. 338-347.

Duniway, M.C., Bestelmeyer, B.T., and Tugel, A., 2010, Soil Processes and properties that distinguish ecological sites and states: Rangelands, v. 32, no. 6, p. 9-15.

Duniway, M.C., Geiger, E.L., Minnick, T.J., Phillips, S.L., and Belnap, J., 2018, Insights from long-term ungrazed and grazed watersheds in a salt desert Colorado Plateau ecosystem: Rangeland Ecology \& Management, v. 71, no. 4, p. 492-505.

Duniway, M.C., and Herrick, J.E., 2013, Assessing impacts of roads-Application of a standard assessment protocol: Rangeland Ecology \& Management, v. 66, no. 3, p. 364 375.

Duniway, M.C., Herrick, J.E., Pyke, D.A., and Toledo, D.P., 2010, Assessing transportation infrastructure impacts on rangelands - Test of a standard rangeland assessment protocol: Rangeland Ecology \& Management, v. 63, no. 5, p. 524-536.

Duniway, M.C., Nauman, T.W., Johanson, J.K., Green, S., Miller, M.E., Williamson, J.C., and Bestelmeyer, B.T., 2016, Generalizing ecological site concepts of the Colorado Plateau for landscape-level applications: Rangelands, v. 38, no. 6, p. 342-349.

Duniway, M.C., and Palmquist, E.C., 2020, Vegetation and Soils Data from an Assessment of Rangeland Ecosystem Conditions in Grand Canyon-Parashant National Monument, Arizona. U.S. Geological Survey data release, https://doi.org/10.5066/P9SJSJHT. 
Duniway, M.C., Pfennigwerth, A.A., Fick, S.E., Nauman, T.W., Belnap, J., and Barger, N.N., 2019, Wind erosion and dust from US drylands - A review of causes, consequences, and solutions in a changing world: Ecosphere, v. 10, no. 3, $28 \mathrm{p}$.

Fleischner, T.L., 1994, Ecological costs of livestock grazing in western North-America: Conservation Biology, v. 8, no. 3, p. 629-644.

Fuller, T.K., 1991, Do pellet counts index white-tailed deer numbers and population change?: The Journal of Wildlife Management, v. 55, no. 3, p. 393-396.

Ganskopp, D., 2001, Manipulating cattle distribution with salt and water in large arid-land pastures-A GPS/GIS assessment: Applied Animal Behaviour Science, v. 73, no. 4, p. 251-262.

Ganskopp, D.C., and Bohnert, D.W., 2009, Landscape nutritional patterns and cattle distribution in rangeland pastures: Applied Animal Behaviour Science, v. 116, no. 2, p. $110-119$.

Garfin, G., Franco, G., Blanco, H., Comrie, A., Gonzalez, P., Piechota, T., Smyth, R., and Waskom, R., 2014, Southwest, chap. 20 of Melillo, J. M., Richmond, T.T.C., and Yohe, G.W., eds., Climate Change Impacts in the United StatesThe Third National Climate Assessment: U.S. Global Change Research Program, p. 462-486.

Godfrey, E.B., 2008, Livestock grazing in Utah-History and status: Report for the Utah Governor's Public Lands Policy Coordination Office, $113 \mathrm{p}$.

Hart, R.H., Bissio, J., Samuel, M.J., and Waggoner, J.W., Jr., 1993, Grazing systems, pasture size, and cattle grazing behavior, distribution and gains: Journal of Range Management, v. 46, no. 1, p. 81-87.

Herrick, J.E., Bestelmeyer, B.T., Archer, S., Tugel, A.J., and Brown, J.R., 2006, An integrated framework for sciencebased arid land management: Journal of Arid Environments, v. 65 , no. 2 , p. $319-335$.

Herrick, J.E., Lessard, V.C., Spaeth, K.E., Shaver, P.L., Dayton, R.S., Pyke, D.A., Jolley, L., and Goebel, J.J., 2010, National ecosystem assessments supported by scientific and local knowledge: Frontiers in Ecology and the Environment, v. 8 , no. 8 , p. $403-408$.

Herrick, J.E., Van Zee, J.W., Havstad, K.M., Burkett, L.M., and Whitford, W.G., 2005, Monitoring manual for grassland, shrubland and savanna ecosystems; Volume II-Design, supplementary methods and interpretation: U.S. Department of Agriculture, Agriculture Research Service, Jornada Experimental Range, 200 p.

Herrick, J.E., Whitford, W.G., de Soyza, A.G., Van Zee, J.W., Havstad, K.M., Seybold, C.A., and Walton, M., 2001, Field soil aggregate stability kit for soil quality and rangeland health evaluations: Catena, v. 44, no. 1, p. 27-35.
Hildebrand, T., and Fertig, W., 2012, Annotated checklist of the vascular plant flora of Grand Canyon-Parashant National Monument phase II report: [Report prepared for] Grand Canyon-Parashant National Monument, 213 p.

Hoover, D.L., Duniway, M.C., and Belnap, J., 2015, Pulsedrought atop press-drought-Unexpected plant responses and implications for dryland ecosystems: Oecologia, v. 179, no. 4, p. 1211-1221.

Jeffries, D.L., and Klopatek, J.M., 1987, Effects of grazing on the vegetation of the blackbrush association: Journal of Range Management, v. 40, no. 5, p. 390-392.

Jones, M.O., Allred, B.W., Naugle, D.E., Maestas, J.D., Donnelly, P., Metz, L.J., Karl, J., Smith, R., Bestelmeyer, B., Boyd, C., Kerby, J.D., and McIver, J.D., 2018, Innovation in rangeland monitoring-Annual, $30 \mathrm{~m}$, plant functional type percent cover maps for U.S. rangelands, 1984-2017: Ecosphere, v. 9, no. 9, 19 p.

Kimuyu, D.M., Veblen, K.E., Riginos, C., Chira, R.M., Githaiga, J.M., and Young, T.P., 2017, Influence of cattle on browsing and grazing wildlife varies with rainfall and presence of megaherbivores: Ecological Applications, v. 27, no. 3, p. 786-798.

Lindsay, B.A., Strait, R.K., and Denny, D.W., 2003, Soil survey of Grand Canyon area, Arizona, parts of Coconino and Mohave Counties: U.S. Department of Agriculture Natural Resouces Convservation Service, p. 603.

Lusby, G.C., 1970, Hydrologic and biotic effects of grazing vs. non-grazing near Grand Junction, Colorado: Journal of Range Management, v. 23, p. 256-260.

Maynard, J.J., and Karl, J.W., 2017, A hyper-temporal remote sensing protocol for high-resolution mapping of ecological sites: PLOS ONE, v. 12, no. 4, 27 p.

Maynard, J.J., Nauman, T.W., Salley, S.W., Bestelmeyer, B.T., Duniway, M.C., Talbot, C.J., and Brown, J.R., 2019, Digital mapping of ecological land units using a nationally scalable modeling framework: Soil Science Society of America Journal, v. 83, p. 666-686.

McArthur, E.D., and Plummer, A.P., 1978, Biogeography and management of native western shrubs-A case study, section Tridentatae of Artemisia: Great Basin Naturalist Memoirs, p. 229-243.

McAuliffe, J.R., 1994, Landscape evolution, soil formation, and ecological patterns and processes in Sonoran Desert bajadas: Ecological Monographs, v. 64, no. 2, p. 111-148.

McCune, B., and Grace, J.B., 2002, Analysis of ecological communities: Gleneden Beach, Oreg., MjM Software Design.

McCune, B., and Mefford, M.J., 2011, PC-ORD, Multivariate analysis of ecological data (ver. 6.08 ed.): Gleneden Beach, Oreg., MjM Software Design. 
Meyer, S.E., and Pendleton, B.K., 2005, Factors affecting seed germination and seedling establishment of a long-lived desert shrub (Coleogyne ramosissima: Rosaceae): Plant Ecology, v. 178, no. 2, p. 171-187.

Miller, M.E., 2008, Broad-scale assessment of rangeland health, Grand Staircase-Escalante National Monument, USA: Rangeland Ecology \& Management, v. 61, p. 249-262.

Miller, M.E., Belote, R.T., Bowker, M.A., and Garman, S.L., 2011, Alternative states of a semiarid grassland ecosystem-Implications for ecosystem services: Ecosphere, v. 2, no. 5, 18 p.

Munson, S.M., Belnap, J., and Okin, G.S., 2011, Responses of wind erosion to climate-induced vegetation changes on the Colorado Plateau: Proceedings of the National Academy of Sciences, v. 108, 6 p.

Munson, S.M., Duniway, M.C., and Johanson, J.K., 2016, Rangeland monitoring reveals long-term plant responses to precipitation and grazing at the landscape scale: Rangeland Ecology \& Management, v. 69, no. 1, p. 76-83.

Munson, S.M., Webb, R.H., Housman, D.C., Veblen, K.E., Nussear, K.E., Beever, E.A., Hartney, K.B., Miriti, M.N., Phillips, S.L., and Fulton, R.E., 2015, Long-term plant responses to climate are moderated by biophysical attributes in a North American desert: Journal of Ecology, v. 103, no. 3, p. 657-668.

National Park Service, 2016, Northern Colorado Plateau Inventory and Monitoring Network, accessed September 20, 2016, at https://www.nps.gov/im/ncpn.

National Research Council, 1994, Rangeland health-New methods to classify, inventory, and monitor rangelands: Washington, D.C., The National Academies Press, 200 p.

Natural Resources Conservation Service, 2006, Land Resource Regions and Major Land Resource Areas of the United States, the Caribbean, and the Pacific Basin: U.S. Department of Agriculture Handbook 296, 2 sheets, 669 p.

Natural Resources Conservation Service, 2018, Ecological site information system, accessed July 26, 2018, at https://esis. sc.egov.usda.gov.

Nauman, T.W., Duniway, M.C., Webb, N.P., and Belnap, J., 2018, Elevated dust emissions on the Colorado Plateau, USA - The role of grazing, vehicle disturbance, and increasing aridity: Earth Surface Processes and Landforms, v. 43, p. 2897-2914.

Neff, J.C., Reynolds, R.L., Belnap, J., and Lamothe, P., 2005, Multi-decadal impacts of grazing on soil physical and biogeochemical properties in southeast Utah: Ecological Applications, v. 15, no. 1, p. 87-95.

Nusser, S.M., and Goebel, J.J., 1997, The National Resources Inventory-A long-term multi-resource monitoring programme: Environmental and Ecological Statistics, v. 4, no. 3, p. 181-204.
Okin, G.S., 2008, A new model of wind erosion in the presence of vegetation: Journal of Geophysical Research, v. 113 , no. F2, $11 \mathrm{p}$.

Peinetti, H.R., Fredrickson, E.L., Peters, D.P.C., Cibils, A.F., Octavio Roacho-Estrada, J., and Laliberte, A.S., 2011, Foraging behavior of heritage versus recently introduced herbivores on desert landscapes of the American Southwest: Ecosphere, v. 2, no. 5, 14 p.

Pellant, M., Shaver, P., Pyke, D., and Herrick, J., 2005, Interpreting indicators of rangeland health, version 4: Bureau of Land Management Technical Reference 1734-6, 122 p.

Poitras, T.B., Villarreal, M.L., Waller, E.K., Nauman, T.W., Miller, M.E., and Duniway, M.C., 2018, Identifying optimal remotely-sensed variables for ecosystem monitoring in Colorado Plateau drylands: Journal of Arid Environments, v. 153 , p. $76-87$.

Pyke, D.A., Herrick, J.E., Shaver, P., and Pellant, M., 2002, Rangeland health attributes and indicators for qualitative assessment: Journal of Range Management, v. 55, no. 6, p. 584-597.

Ramcharan, A., Hengl, T., Nauman, T., Brungard, C., Waltman, S., Wills, S., and Thompson, J., 2018, Soil property and class maps of the conterminous United States at 100-meter spatial resolution: Soil Science Society of America Journal, v. 82, no. 1, 16 p.

Rango, A., Tartowski, S.L., Laliberte, A., Wainright, J., and Parsons, A., 2006, Islands of hydrologically enhanced biotic productivity in natural and managed arid ecosystems: Journal of Arid Environments, v. 65, p. 235-252.

Rider, R.W., and Paulsen, D.M., 1985, The Roll Away Saloon, Cowboy Tales of the Arizona Strip: Logan, Utah State University Press, $114 \mathrm{p}$.

Riley, S.J., DeGloria, S.D., and Elliot, R., 1999, A terrain index that quantifies topographic heterogeneity: Intermountain Journal of Science, v. 5, p. 23-27.

Sala, O.E., Parton, W.J., Joyce, L.A., and Lauenroth, W.K., 1988, Primary production of the central grassland region of the United States: Ecology, v. 69, no. 1, p. 40-45.

Salley, S.W., Talbot, C.J., and Brown, J.R., 2016, The Natural Resources Conservation Service land resource hierarchy and ecological sites: Soil Science Society of America Journal, v. 80 , no. 1,9 p.

Schaap, M.G., Leij, F.J., and van Genuchten, M.T., 2001, ROSETTA - A computer program for estimating soil hydraulic parameters with hierarchical pedotransfer functions: Journal of Hydrology, v. 251, no. 3-4, p. 163-176. 
Schlaepfer, D.R., Lauenroth, W.K., and Bradford, J.B., 2011, Ecohydrological niche of sagebrush ecosystems: Ecohydrology, v. 5, p. 453-466.

Schoeneberger, P., Wysocki, D., Benham, E., Broderson, W., and Soil Survey staff, 2012, Field book for describing and sampling soils, version 3.0: Lincoln, Nebr., Natural Resources Conservation Service, $284 \mathrm{p}$.

Seager, R., Ting, M., Held, I., Kushnir, Y., Lu, J., Vecchi, G., Huang, H.P., Harnik, N., Leetmaa, A., Lau, N.C., Li, C., Velez, J., and Naik, N., 2007, Model projections of an imminent transition to a more arid climate in southwestern North America: Science, v. 316, no. 5828, p. 1181-1184.

Senft, R.L., Rittenhouse, L.R., and Woodmansee, R.G., 1983, The use of regression models to predict spatial patterns of cattle behavior: Journal of Range Management, v. 36, no. 5, p. 553-557.

Sörensen, R., Zinko, U., and Seibert, J., 2006, On the calculation of the topographic wetness index-Evaluation of different methods based on field observations: Hydrology and Earth System Sciences Discussions, v. 10, no. 1, p. $101-112$.

Spiegal, S., Estell, R.E., Cibils, A.F., James, D.K., Peinetti, H.R., Browning, D.M., Romig, K.B., Gonzalez, A.L., Lyons, A.J., and Bestelmeyer, B.T., 2019, Seasonal divergence of landscape use by heritage and conventional cattle on desert rangeland: Rangeland Ecology \& Management, v. 72, no. 4, p. 590-601.

Steele, C.M., Bestelmeyer, B.T., Burkett, L.M., Smith, P.L., and Yanoff, S., 2012, Spatially explicit representation of state-and-transition models: Rangeland Ecology \& Management, v. 65, no. 3, p. 213-222.

Steers, R.J., and Allen, E.B., 2010, Post-fire control of invasive plants promotes native recovery in a burned desert shrubland: Restoration Ecology, v. 18, no. s2, p. 334-343.

Stevens, D.L., and Olsen, A.R., 2004, Spatially balanced sampling of natural resources: Journal of the American Statistical Association, v. 99, no. 465, p. 262-278.

Thoma, D.P., Munson, S.M., and Witwicki, D.L., 2018, Landscape pivot points and responses to water balance in national parks of the southwest U.S: Journal of Applied Ecology, v. 56, no. 1, p. 157-167.

Toevs, G.R., Karl, J.W., Taylor, J.J., Spurrier, C.S., Karl, M.S., Bobo, M.R., and Herrick, J.E., 2011, Consistent indicators and methods and a scalable sample design to meet assessment, inventory, and monitoring information needs across scales: Rangelands, v. 33, no. 4, p. 14-20.
Tongway, D.J., and Hindley, N.L., 2004, Landscape function analysis: Procedures for monitoring and assessing landscapes with special reference to minesites and rangelands: Canberra, Australia, CSIRO Sustainable Ecosystems.

Tongway, D.J., and Ludwig, J.A., 1997, The conservation of water and nutrients within landscapes, in Ludwig, J., Tongway, D., Freudenberger, D., Noble, J., and Hodgkinson, K., eds., Landscape Ecology, Function and ManagementPrinciples from Australia's Rangelands: Collingwood, Australia, CSIRO Sustainable Ecosystems, p. 13-22.

Tongway, D., Sparrow, A., and Friedel, A., 2003, Degradation and recovery processes in arid grazing lands of central Australia; Part 1, Soil and land resources: Journal of Arid Environments, v. 55, no. 2, p. 301-326.

Turner, G.T., 1971, Soil and grazing influences on a saltdesert shrub range in western Colorado: Journal of Range Management, v. 24, p. 31-37.

Ungar, E.D., Henkin, Z., Gutman, M., Dolev, A., Genizi, A., and Ganskopp, D., 2005, Inference of animal activity from GPS collar data on free-ranging cattle: Rangeland Ecology \& Management, v. 58, no. 3, p. 256-266.

Veblen, K.E., 2012, Savanna glade hotspots-Plant community development and synergy with large herbivores: Journal of Arid Environments, v. 78, p. 119-127.

Wade, T.G., Schultz, B.W., Wickham, J.D., and Bradford, D.F., 1998, Modeling the potential spatial distribution of beef cattle grazing using a Geographic Information System: Journal of Arid Environments, v. 38, no. 2, p. 325-334.

Warren, S.D., Thurow, T.L., Blackburn, W.H., and Garza, N.E., 1986, The influence of livestock trampling under intensive rotation grazing on soil hydrologic characteristics: Journal of Range Management, v. 39, p. 491-495.

Webb, N.P., Herrick, J.E., and Duniway, M.C., 2014, Ecological site-based assessments of wind and water erosion-Informing accelerated soil erosion management in rangelands: Ecological Applications, v. 24, no. 6, p. 1405-1420.

Whitford, W.G., 2002, Ecology of Desert Systems: San Diego, Calif., Academic Press, 343 p.

Williamson, J.C., Bestelmeyer, B.T., McClaran, M.P., Robinett, D., Briske, D.D., Wu, X.B., and FernándezGiménez, M.E., 2016, Can ecological land classification increase the utility of vegetation monitoring data?: Ecological Indicators, v. 69, p. 657-666. 


\section{Appendix 1. Identification of Hydrologically Enhanced Areas}

The identification of hydrologically enhanced areas was done using the maximum likelihood classification tool in the Spatial Analyst extension of ArcGIS (ver. 10.1). More than 3,000 training polygons were manually digitized through examination of contemporary 1-meter color aerial imagery in the study area. Observers visually inspected aerial photographs with overlaid shaded-relief layers and created circular polygon features that either had (1) evidence of increased productivity or water accumulation (coded as "1") or (2) were clearly upland areas without significant run-in (coded as "2"). These polygons were then used to create a supervised classification within shallow-slope soil-geologic strata (table 3) and, based on multiple terrain derivatives (table 1.1), signatures extracted and classified. Cells classified as hydrologically enhanced and with slopes less than $8^{\circ}$ were then put into the "run-in" strata. This was accomplished using the model builder in ArcCatalog.

Table 1.1. Raster input layers for the supervised classification of hydrologically enhanced areas used in the study sample design.

[Derivatives were calculated using Spatial Analyst (ArcMap ver. 10.1) and a 10-meter digital elevation model (DEM) from the U.S. Geological Survey National Elevation Dataset (https://nationalmap.gov). m, meters]

\begin{tabular}{ll}
\hline \multicolumn{1}{c}{ DEM-derived layer } & \multicolumn{1}{c}{ Description } \\
\hline Relative elevation & $\begin{array}{c}\text { Difference in elevation between local mean }(0-20 \mathrm{~m} \text { from cell center) and annular ring at } 70-80 \mathrm{~m} \\
\text { distance } \\
\text { Mean of } 1 \log 10 \text {-flow accumulation in a } 30 \mathrm{~m} \text { radius around the target pixel }\end{array}$ \\
$\begin{array}{ll}\text { Flow accumulation } \\
\text { Distance to stream or other drainage }\end{array}$ & $\begin{array}{l}\text { Horizontal distance to stream or other drainage (identified using flow accumulation raster) based on } \\
\text { water-flow patterns (using cost distance tool) }\end{array}$ \\
Height above stream or other drainage & Elevation (in meters) above closest stream or drainage \\
\hline
\end{tabular}


Moffet Field Publishing Service Center, California Manuscript approved for publication April 27, 2020 Edited by Monica Edman

Layout and design by Kimber Petersen 


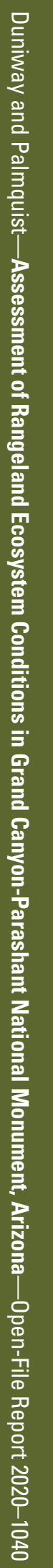

